Florida International University FIU Digital Commons

$11-8-2013$

\title{
Hermetic Text and Subtext: Paranormal Phenomena in the Works of Alejandro Tapia y Rivera and Benito Pérez Galdós
}

Agnes Ruiz-López

aruiz025@fiu.edu

DOI: $10.25148 /$ etd.FI13121210

Follow this and additional works at: https:// digitalcommons.fiu.edu/etd

Part of the Latin American Literature Commons, Metaphysics Commons, and the Spanish Literature Commons

\section{Recommended Citation}

Ruiz-López, Agnes, "Hermetic Text and Subtext: Paranormal Phenomena in the Works of Alejandro Tapia y Rivera and Benito Pérez Galdós" (2013). FIU Electronic Theses and Dissertations. 1037.

https://digitalcommons.fiu.edu/etd/1037 


\title{
FLORIDA INTERNATIONAL UNIVERSITY
}

\author{
Miami, Florida
}

\section{HERMETIC TEXT AND SUBTEXT: PARANORMAL PHENOMENA IN THE WORKS OF ALEJANDRO TAPIA Y RIVERA AND BENITO PÉREZ GALDÓS}

\author{
A dissertation submitted in partial fulfillment of \\ the requirements for the degree of \\ DOCTOR OF PHILOSOPHY \\ in \\ SPANISH \\ by
}

Agnes Ruiz-López

2013 
To: Dean Kenneth Furton

College of Arts and Sciences

This dissertation, written by Agnes Ruiz-López, and entitled Hermetic Text and Subtext: Paranormal Phenomena in the Works of Alejandro Tapia y Rivera and Benito Pérez Galdós, having been approved in respect to style and intellectual content, is referred to you for judgment.

We have read this dissertation and recommend that it be approved.

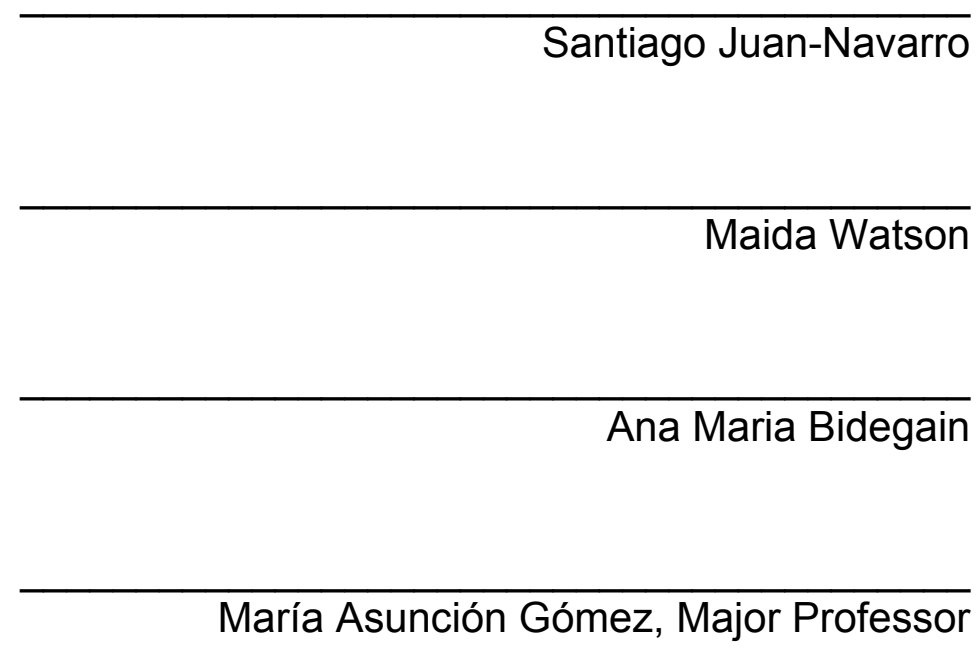

Date of Defense: November 8, 2013

The dissertation of Agnes Ruiz-López is approved.

$\begin{array}{r}\text { Dean Kenneth G. Furton } \\ \text { College of Arts and Sciences } \\ \hline \begin{array}{r}\text { Dean Lakshmi N. Reddi } \\ \text { University Graduate School }\end{array}\end{array}$

Florida International University, 2013 


\section{DEDICATION}

I lovingly dedicate this dissertation to my mother, Luisa López-Díaz; and to my constant companions, Sebastian Alejandro and Gabriela Maria. 


\section{ACKNOWLEDGMENTS}

I would like to express my deepest appreciation to my advisor and committee chair, Dr. María Asunción Gómez, who has so patiently guided me throughout this whole process. Also, I would like to thank the members of my committee, Dr. Santiago Juan-Navarro, Dr. Maida Watson, and Dr. Ana Maria Bidegain for their support. Last, but definitely not least, to Ms. Rosa SantiagoOstolaza and Mr. Louis Perez for their generous help, continuous encouragement, and unending coffee supply. 


\begin{abstract}
OF THE DISSERTATION
HERMETIC TEXT AND SUBTEXT: PARANORMAL PHENOMENA IN THE

WORKS OF ALEJANDRO TAPIA Y RIVERA AND BENITO PÉREZ GALDÓS

by
\end{abstract}

Agnes Ruiz-López

Florida International University, 2013

Miami, Florida

Professor María Asunción Gómez, Major Professor

This research seeks to establish a connection between the Hermetic tradition and the paranormal phenomena found in the works of Alejandro Tapia y Rivera --- “Un alma en pena” (1862), Póstumo el transmigrado (1872) and Póstumo el envirginado (1882) --- and Benito Pérez Galdós's La sombra (1870) and "Celín" (1871). By establishing a Hegelian influence in their works, we uncover the possible origin of these paranormal events.

German Idealism, so widespread during the first half of the $19^{\text {th }}$ century, seems to have given both authors access to new currents of thought, allowing them to explore the union of art with the metaphysical. Thought is given precedence over sensation and Idealism prevails over Empiricism. Nature is now seen to be spiritual, as well as spatial, and among the major exponents of this movement is Georg Wilhelm Friedrich Hegel (1770-1831), whose philosophy states that human knowledge is based on the "Idea," a concept in which nature and spirit fuse. 
Hegel holds the traditional hermetic conception of philosophia perennis that supposes a universal truth common to every culture, religious tradition, and belief upheld by humankind. By examining the Hegelian influence in the works of Alejandro Tapia y Rivera and Benito Pérez Galdós, and relating major passages of their works to the precepts contained in the Corpus Hermeticum, the Emerald Tablet, and the Kybalion (1908), we uncover a subtle, sometimes explicit, presence of this esoteric doctrine, which allows the authors to explore the metaphysical side of life. 


\section{TABLE OF CONTENTS}

CHAPTER

PAGE

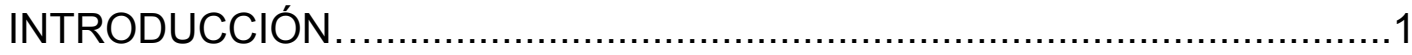

I. Tapia y Galdós en su contexto histórico..............................12

II. Bajo el influjo del "Sturm und Drang" ..............................29

III. “Celín": Vibración y ritmo universal....................................61

IV. Póstumo, transmigrado y envirginiado: Paradoja divina y creación generadora ............................................................ 90

V. La sombra: sustancia mental y causalidad..........................119

VI. "Un alma en pena": Naturaleza universal y dimensiones espaciales

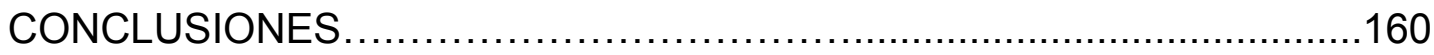

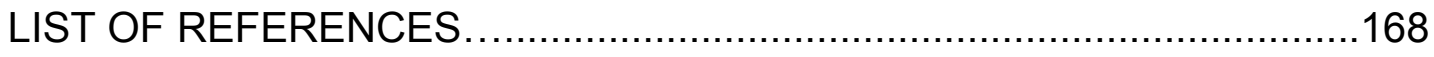

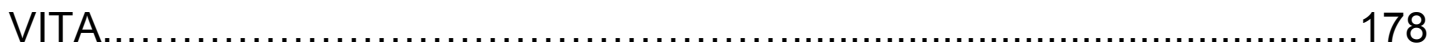




\section{INTRODUCCIÓN}

Conectando los puntos de encuentro

Magnum, o Asclepi, miraculum est homo

Hermes Trismegisto

We see only what we know Johann Wolfgang von Goethe

En las obras "Un alma en pena” (1862), Póstumo el transmigrado (1872) y su continuación, Póstumo el envirginado (1882) de Alejandro Tapia y Rivera (1826-1882), al igual que en "Celín" (1887) y La sombra (1870) de Benito Pérez Galdós (1843-1910), puede advertirse una curiosa similitud: todas se encuentran enmarcadas en un ámbito paranormal en el que se desafían las leyes físicas naturales. Los protagonistas experimentan fenómenos extrasensoriales que guardan una serie de puntos de encuentro con los preceptos de la antigua tradición hermética. ${ }^{1}$ A primera vista, estas características podrían atribuírsele al siglo en que a ambos autores les toca vivir y crear. En el siglo XIX, la imaginación y la pasión por todo lo extraño e inexplicable ocupan un lugar importante dentro de la estética literaria. No obstante, el presente estudio busca establecer una relación más específica, reinterpretando los sucesos de origen paranormal en las obras de Tapia y Rivera y de Pérez Galdós a la luz de la tradición hermética, y teniendo en

\footnotetext{
${ }^{1}$ El hermetismo o tradición hermética, es una milenaria disciplina basada en un grupo de postulados esotéricos supuestamente escritos por Hermes "Trismegisto" o "tres veces grande" (celebrado como sacerdote, rey y erudito), figura que parece ser la fusión sincrética del dios egipcio "Tot" con la del Hermes griego. Este conjunto de textos herméticos se compone de una serie de tratados y diálogos griegos y latinos escritos en el siglo I o II d.c., aunque contiene ideas y postulados probablemente mucho más antiguos (Magee 1).
} 
cuenta la influencia del idealismo alemán, en especial del filósofo Georg Wilhelm Friedrich Hegel (1770-1831). Con esto propongo una interpretación de corte hermético que plantea una exégesis del universo de los personajes creados por estos escritores que a primera vista podrían considerarse considerablemente disímiles.

Mi tesis se basa en gran parte en la obra Hegel and the Hermetic Tradition de Glenn Alexander Magee, que sostiene que la filosofía hegeliana entraña una indudable influencia hermética, aparte de aceptar la enseñanza central de que Dios se realiza y se completa sólo cuando el hombre descubre la existencia de este y lo reconoce. En la obra hegeliana se hallan correspondencias asombrosas con la teosofía hermética, y estas equivalencias, de acuerdo a lo planteado por Magee, no son accidentales, puesto que el filósofo germano se interesó por el hermetismo desde muy temprana edad, y tuvo contacto con movimientos y pensadores herméticos durante toda su vida. ${ }^{2}$ Entonces, no es de extrañar que tanto en las publicaciones como en los escritos inéditos de Hegel se encuentren referencias a muchas de las principales figuras y movimientos de la tradición hermética. (Magee 2-3). ${ }^{3}$

\footnotetext{
${ }^{2}$ Por lo general se piensa en Hegel dentro del contexto de la tradición filosófica alemana y en relación con la filosofía kantiana. Naturalmente, la influencia kantiana, es de gran importancia, pero no es la única filosofía que deja huella en la obra hegeliana. Es importante recordar que la niñez de Hegel transcurre en la ciudad de Stuttgart (1770-1788), en la región de Württemberg, un importante centro de interés hermético.

${ }^{3}$ El movimiento pietista recibe el influjo místico de Böhmen y de los rosacruces (Württemberg fue el centro espiritual del movimiento rosacruz). Cabe señalar que los principales exponentes del pietismo (J.A. Bengel y, en particular, F.C. Oetinger)
} 
La publicación en 1781 de la Crítica de la razón pura de Immanuel Kant (1724-1804) marcó el comienzo de la corriente filosófica conocida como idealismo alemán. El "idealismo trascendental" de Kant gira en torno a la idea de que el mundo no puede conocerse como en realidad es, sino como lo experimentamos. El tiempo y el espacio, por ejemplo, no son características objetivas, sino más bien formas de nuestra experiencia. Kant reconoce que hay cosas que no dependen de la mente humana para su existencia, y las llamó "cosas en sí mismas". Sin embargo, insistió en que los objetos que realmente experimentamos no son las cosas en sí mismas, sino la mera apariencia de estas cosas, y esa apariencia sólo existe en nuestras mentes.

Hegel, por su parte, concibió una filosofía en la que el conocimiento humano se basa en la "idea", un concepto en el que la Naturaleza se funde con el espíritu. De esta manera pretende reconectar la ciencia con lo divino al mostrar a un dios que se expresa mediante su creación. Hegel no rechaza el método científico, pero sí busca zanjar la brecha entre los intelectuales y el hombre común. El sistema filosófico hegeliano promete una experiencia transformadora del mundo, mediante la cual las cosas familiares se nos presentan bajo una nueva luz. La ciencia, la poesía, el arte, la religión, el Estado, son descritos como expresiones o formas de realización de la "Idea Absoluta", y así las cosas cotidianas pronto adquieren un nuevo significado (Magee 97). Si bien Hegel opina que las ciencias naturales devalúan o

recibieron una gran influencia del misticismo alemán, la teosofía de Böhmen y la Cábala (Magee 3). 
anulan la experiencia humana, este incorpora en su sistema los datos científicos de su tiempo, y los enmarca en una filosofía de la Naturaleza. Además, Hegel se adhiere a la creencia en la philosophia perennis, perspectiva que supone una verdad universal común a todas las culturas, tradiciones religiosas y creencias de la humanidad, y para muchos ese origen reside en la tradición hermética. ${ }^{4}$

A partir de estas ideas, Alejandro Tapia y Rivera, "preceptista y crítico... y no ajeno a los estudios filosóficos", compone "sus Conferencias de estética y literatura, inspiradas por el criterio hegeliano" (Menéndez Pelayo, Historia de la poesía hispanoamericana 337). La obra galdosiana, por su parte, se basa en el pensamiento del siglo XIX en general, y encuentra en Hegel, sobre todo en la idea de que "estar en uno mismo" es "estar en el otro", un sólido fundamento para sus inclinaciones metafísicas (Las novelas, Eoff 150). De hecho, en una reseña de 1872 acerca de la traducción al español de la Lógica de Hegel, el propio Galdós lo describe como "libro oportunísimo, no sólo por su mérito intrínseco, sino porque los estragos que en entendimientos muy ilustrados hace la escuela positivista, exigen grandes esfuerzos para devolver a la metafísica el puesto que le corresponde entre los acontecimientos humanos" (citado en Rodgers 130).

\footnotetext{
${ }^{4}$ El término philosophia perennis fue utilizado por primera vez por Gottfried Wilhelm Leibniz (1646-1716), quien lo tomó de la obra del teólogo Agostino Steuco (1540). Steuco lo usó para describir la verdad absoluta originalmente revelada al hombre antes de su caída, y recuperada gradualmente en forma fragmentaria en la historia del pensamiento humano (Dible 174). Pico della Mirandola y Marsilio Ficino prepararon el camino para Steuco llamando a Hermes "el primer teólogo" (Faivre 39).
} 
La importancia de este estudio es triple. A pesar de que las obras de Benito Pérez Galdós han sido ampliamente analizadas, el tema de lo paranormal en su narrativa sigue un tanto relegado. En cuanto a Alejandro Tapia y Rivera, este es mucho más conocido por sus dramas, en especial La cuarterona, por lo que su cuentística merece un análisis más detallado. ${ }^{5}$ Por último, en lo que respecta a estos dos autores, nunca se ha realizado un estudio comparativo de sus obras.

En los siguientes capítulos se identifican los hilos que conectan la filosofía hegeliana y la hermética en el gran tapiz literario de estas dos importantes figuras de la escritura hispánica. El primer capítulo contextualiza el periodo histórico-filosófico que moldea el mundo literario de ambos autores. En el próximo capítulo se exploran los orígenes del idealismo alemán, del romanticismo y de la filosofía hegeliana, y se sigue el desarrollo de la doctrina hermética y sus conexiones con las ideas de Hegel.

En el capítulo tercero comienza el análisis de las obras con el cuento "Celín", de Benito Pérez Galdós, una especie de "Bildungsroman" que cuenta la historia de una joven suicida, su enigmático lazarillo y las variaciones espaciales provocadas por el misterioso movimiento de la ciudad que

\footnotetext{
${ }^{5}$ Es la historia del amor desafortunado entre Julia, una joven mulata de piel clara, y su amante, el Conde Carlos. Publicada en España en 1867, fue censurada durante muchos años en Puerto Rico por su crítica de la sociedad burguesa terrateniente --que había amasado su riqueza con la explotación de los esclavos--- y por su perspectiva abolicionista, ya que es "la única obra dramática antiesclavista que fuera escrita por autor antillano en tiempos de esclavitud” (Benítez Rojo 8).
} 
recorren. ${ }^{6}$ "Celín" es una obra que se encuentra emparentada con el resto de la producción galdosiana, puesto que "hay una continuidad esencial en la obra de Galdós, incluso entre obras a primera vista dispares" (Gutiérrez DíazBernardo 32-33). Sebastián de la Nuez señala que ya ha quedado más que demostrado "que la obra de Galdós se mueve entre el mundo de la realidad y lo maravilloso, entre los hechos cotidianos y los sueños visionarios, que hay una veta fantástica que se desborda... de su obra general" (181), y como prueba nos remite a la primera novela galdosiana, La sombra (1868), a la fábula teatral "La razón de la sinrazón" (1915) y a otros relatos menos conocidos como "El caballero encantado" (1909), "cuento real inverosímil" (De la Nuez 181). ${ }^{7}$ Sin embargo, vistos en términos herméticos, los acontecimientos pueden explicarse mediante los principios de vibración y de ritmo. El primero establece que todo se encuentra en constante movimiento y vibrando en diferentes frecuencias, mientras que el segundo indica que todo fluye, todo oscila, y por cada acción hay una reacción (El kybalión 12, 15). De manera análoga, las divisiones de la filosofía hegeliana siguen un patrón

\footnotetext{
${ }^{6}$ En 1887, Benito Pérez Galdós escribe el cuento "Celín" que saldría a la luz en Los meses, una "colección de artículos... publicados en Barcelona con grandísimo lujo", para la que un grupo selecto de escritores recibió el encargo de escribir siguiendo como pie forzado uno de los doce meces del año (Pérez Galdós, "Prólogos" 67). "Celín" ---la representación simbólica del mes de noviembre ---resurgiría más tarde en la antología galdosiana La sombra (1890), donde además de la novela corta que da título a la colección, se incluirían los cuentos "Tropiquillos", donde se cuenta la historia de un marino que llega a su casa, enfermo y arruinado. Su antiguo criado ahora es un hombre rico que lo ampara, y "Theros", un relato cuyo protagonista se encuentra con una hermosa mujer que parece encenderse en ardientes llamas durante el día y apagarse durante la noche.

${ }^{7}$ El crítico propone ---a la luz de lo que Todorov cataloga como literatura fantástica-que el desarrollo de esta historia presenta lo extraño y lo maravilloso para luego desembocar en un final con "una explicación racional" de tales acontecimientos.
} 
similar al de la filosofía hermética, ya que estas representan una etapa inicial de "purificación", de elevar la mente por encima del nivel de lo sensorial y lo mundano al nivel puro de lo eterno, de la "mente universal" (Idea Absoluta). Es decir, el "retorno" de la Naturaleza al ámbito de lo divino gracias a la observación y al reconocimiento que hace el hombre de esta (Magee 4). Se verá el motivo de la circularidad representado en el recorrido geográfico de los personajes y en la transformación de la protagonista, que gracias al conocimiento de esa exuberante Naturaleza llega a alcanzar el conocimiento de Dios.

En el cuarto capítulo se analizará la novela de Alejandro Tapia y Rivera, Póstumo el transmigrado: historia de un hombre que resucitó en el cuerpo de su enemigo (1872) y su continuación, Póstumo el envirginado o historia de un hombre que se coló en el cuerpo de una mujer (1882). ${ }^{8}$ La primera parte cuenta la historia de Póstumo, un hombre que reencarna por decisión propia en el cuerpo de su rival, enfrentándose así al principio universal de la dualidad o polaridad, y afrontando múltiples retos para hallar una verdadera armonía existencial. ${ }^{9}$ En la segunda parte, Póstumo el

\footnotetext{
${ }^{8}$ En 1933, en una carta dirigida al hijo de Alejandro Tapia y Rivera, el traductor alemán K. W. Körner comenta que "Póstumo no sólo tiene máximo interés por la historia literaria como intermedio entre la vieja novela picaresca española y la moderna sátira a la Anatole France, sino es también, por [sic] un largo público, una lectura gratísima" (Tapia y Rivera, “Introducción” Póstumo el transmigrado 582).

${ }^{9}$ Los críticos también se han ocupado de señalar el tema del espiritismo en el relato, resaltando el hecho de que varios cuentos y novelas tapianas presentan temas relacionados con el espiritismo. Es importante recordar que las doctrinas y prácticas de lo que se conoce como "espiritismo científico", también identificado como "espiritismo de mesa blanca", tuvieron un significativo impacto cultural en las sociedades, tanto de Cuba como de Puerto Rico desde que se introdujo en las islas en la segunda mitad del siglo XIX. Aunque durante esta época las religiones de
} 
envirginiado, vuelve el alma de nuestro protagonista a encarnar, esta vez en el cuerpo de una mujer. Ahora no sólo lucha por armonizar su existencia física y espiritual, sino que además debe enfrentarse al principio de la dualidad de los sexos y sus consabidas diferencias. Examinamos cómo, de acuerdo con la hermética, todo tiene dos polos o su par de opuestos que no son sino los extremos de la misma cosa, es decir, "tesis y antítesis son idénticas en naturaleza, pero diferentes en grado" (El kybalión 13).

Destacamos, además, el hecho de que para Hegel la "unión de lo individual y de lo universal, es una mezcla... que guarda... su existencia independiente frente a lo universal, con quien está al mismo tiempo en relación" y "contiene, por consecuencia, la contradicción multiforme de la individualidad" (Filosofía del espíritu 312-13). A la luz de estas ideas, revisamos las reencarnaciones de Póstumo y tratamos de identificar las características que le hacen un ser doble que va en busca de unidad.

El quinto capítulo se ocupa de la novela galdosiana La sombra, escrita en 1890, y que Germán Gullón describe como un "cruce de imaginación y fantasía" (351). ${ }^{10}$ Este relato presenta un estudio psicológico de su

origen africano ya se habían consolidado dentro de estas sociedades caribeñas, las tendencias espiritualistas "modernas" de América del Norte y de Europa se estaban colando en la región (Saldivia-Berlung 33).

${ }^{10}$ De acuerdo al prólogo escrito por el propio Galdós en la colección que lleva el mismo nombre, esta novela "data de una época que se pierde en la noche de los tiempos... aunque, relacionándola con otros hechos de la vida del autor, puedo referirla vagamente a los años 66 ó 67" (Pérez Galdós, "Prólogos" 67). Por su parte, José F. Montesinos concluye que Galdós comienza a escribirla en 1868, y aparece publicada por entregas en 1870 en la "Revista de España", por tanto puede catalogarse como la primera novela escrita por el autor, aunque La fontana de oro haya sido la primera en publicarse (52). 
protagonista, Anselmo, hombre que ha luchado toda su vida contra una enfermedad mental ---al parecer congénita--- y sus trágicas consecuencias. Consideraremos aquí los postulados herméticos del "mentalismo" y de "causa y efecto". Según el primero, todo lo que es evidente a nuestros sentidos es producto de la mente, que a su vez emula la actividad de la gran "mente universal" o en términos hegelianos, la "idea absoluta". Mientras que, conforme con el principio universal de la causalidad todo suceso se relaciona en última instancia con una secuencia infinita e ininterrumpida de acontecimientos encadenados. Si, como establecen las leyes de la física, el universo está compuesto por energía en constante estado vibratorio y, como declara la hermética, toda forma de energía puede ser moldeada por el pensamiento, entonces es posible manifestar un efecto observable en el plano físico. Desde el punto de vista de quien realiza la acción de pensar, lo creado por su mente es una realidad. De esta manera, Anselmo, con su poder mental crea una realidad fatídica que le lleva a sufrir las consecuencias de su pensamiento desenfrenado.

La última de las obras estudiadas es el cuento "Un alma en pena", de Alejandro Tapia y Rivera, el cual presenta una singular historia de amor en la que el protagonista, luego de sufrir la muerte de su amada, comienza a experimentar fenómenos paranormales, a la vez que recibe pruebas empíricas desde el más allá. En este relato, más que un subtexto hermético tenemos una referencia textual extraordinariamente clara. Alfredo se cuestiona la idea de un mundo "sobrenatural", proponiendo que tal concepto 
no debería existir, puesto que todo se encuentra dentro de lo que denominamos "Naturaleza". En la narración se hace una abierta alusión a la máxima hermética contenida en la Tabla de Esmeralda o Esmeraldina ${ }^{11}$ : "Lo que está en lo alto es como lo que está en lo bajo; lo que está encima es como lo que está debajo". Este precepto declara una armonía, acuerdo y correspondencia entre los diferentes planos de manifestación universal. La filosofía hermética considera que el universo puede dividirse en tres grandes clases de fenómenos conocidos como los tres grandes planos, a saber: el físico, el mental y el espiritual, y asegura que todo lo que está contenido en el universo emana de la misma fuente, por lo que las mismas leyes, principios y características se aplican a todo cuanto existe. Análogamente, en el hegelianismo encontramos que, aunque vivimos en un universo en el que todo se encuentra organizado jerárquicamente, existen energías cósmicas que lo relacionan y unifican todo mediante fuerzas o poderes divinos (Magee 13). Esta correspondencia habilita al hombre para razonar inteligentemente desde lo conocido hasta lo desconocido (El kybalión 26). Es precisamente esta capacidad de observación y deducción la que le ha llevado a descubrir y a explicar la existencia de las leyes naturales a la luz de las ciencias de la física.

De manera que, veremos cómo las influencias directas e indirectas del hermetismo en la literatura de Alejandro Tapia y Rivera y de Benito Pérez Galdós, abren nuevas posibilidades de interpretación de las obras de ambos

\footnotetext{
${ }^{11}$ Breve texto hermético que se dice contiene doce máximas alquímicas escritas por el propio Hermes Trismegisto, y del cual nos ocuparemos en el segundo capítulo.
} 
autores que examinaremos a continuación, y nos permitirán explorar los diversos aspectos metafísicos que a primera vista podrían considerarse meros inventos fantásticos. 


\section{CAPÍTULO I}

Tapia y Galdós en su contexto histórico-literario

Triste la hermosa Borinquen gemía arrastrando la mísera pobreza, ella que el don de perenal riqueza en sus campos feraces contenía.

Alejandro Tapia y Rivera

Podría decirse que la sociedad llega a un punto de su camino en que se ve rodeada de ingentes rocas que le cierran el paso. Diversas grietas se abren en la dura y pavorosa peña, indicándonos senderos o salidas que tal vez nos conduzcan a regiones despejadas.

Benito Pérez Galdós

El siglo XIX representa un periodo de extrema conmoción política y social tanto en España como en las Américas, conmoción que se extiende hasta bastante entrado el siglo. Las primeras décadas traen consigo la decadencia de las colonias, muchas de las cuales habían ganado su independencia. El resto del siglo se presenta plagado de problemas políticos internos: las guerras carlistas, intrigas palaciegas, la Revolución de 1868, el breve reinado de Amadeo de Saboya, la abortada primera república y la Restauración borbónica. Estas transformaciones político-sociales condicionan tanto el desarrollo de la literatura española como el de la literatura que se produce en Hispanoamérica. Por otra parte, cabe señalar que el surgimiento de corrientes de pensamiento como el rousseaunianismo, el positivismo, el krausismo y el idealismo filosófico proveen a los intelectuales de la época nuevas opciones creativas. De manera que, para 
verdaderamente comprender las obras de Alejandro Tapia y Rivera y Benito Pérez Galdós, resulta necesario echar una mirada al contexto histórico y literario de ambos escritores, e identificar las corrientes literarias y filosóficas que influyen en sus obras.

En el Puerto Rico decimonónico, desde la llegada de los españoles a la Isla en 1493, había imperado una lenta y letárgica existencia a causa de la centralidad de la política y la economía monárquica, que no proveía oportunidad de expansión cultural. No obstante, en este clima de represión y carencia encontramos que Alejandro Tapia y Rivera se destaca como "la más grande figura de la naciente literatura puertorriqueña del siglo XIX" (Rivera de Álvarez 144). Ejerce como dramaturgo, novelista, poeta, historiador, esteta, y es uno de los autores en que el movimiento romántico alcanza en Puerto Rico "su más efectiva expresión" (Manrique Cabrera 113) Asimismo, "abrió unos espacios literarios por donde habrían de transitar más tarde muchos de nuestros escritores de fin de siglo y aun los contemporáneos" (RománEyxarch xiii). ${ }^{12}$ Manuel Fernández Juncos describe a Tapia como "arrebatado, impresionable y extraordinariamente vivo de genio" y recalca que "con un carácter más reflexivo y positivista, no hubiera llegado Tapia a

\footnotetext{
${ }^{12}$ Tapia escribe el cuento "El heliotropo" (1848) diez años antes que "Gaspar Blondín" de Juan Montalvo (1858) el cual se considera como el primer cuento fantástico hispanoamericano. Asimismo, el tema de la trasmigración de las almas se dice apareció por primera vez en la literatura hispanoamericana con El ángel de la sombra (1926) del argentino Leopoldo Lugones, no obstante Póstumo el transmigrado se publica con 54 años de anterioridad. De igual forma, la primera aparición del tema del doble en Hispanoamérica se le atribuye a Eduardo L. Holmberg con "El ruiseñor y el artista" (1881), sin embargo, los "Póstumos" ya habían comenzado a publicarse en 1872 (Martell Morales 171-72).
} 
merecer el título de primer apóstol de las letras de Puerto Rico" (59). Por otra parte Elsa Castro Pérez afirma que Tapia se adelantó a su época y "fue un constante propagador de las ideas estéticas de Hegel, de la libertad de la mujer en la sociedad, y aunque de raíz romántica, es un criticista de abolengo dieciochesco" (54). Sin embargo, Tapia no alcanza el reconocimiento que merece, especialmente dentro del canon de la literatura hispanoamericana de la época, ya que la difusión de su obra y "los acercamientos exegéticos de la misma, no han sido suficientes como para descubrirle al lector hispanoparlante una figura de gran trascendencia en las letras antillanas, hispanoamericanas y, por tanto, universales" (Moreira 1).

La obra tapiana se desarrolla bajo la sombra de las desventajosas condiciones del Puerto Rico de la época "doblemente aislado por la geografía y la suspicacia gubernamental", carente de instituciones educativas adecuadas y "sin prensa periódica fiscalizadora, ni derecho de reunión... subordinado todo, gobierno, pueblo, leyes y familias a la influencia corrosiva de los ingenios azucareros servidos por los esclavos" (Brau 325). Por tales razones, Tapia utiliza su obra para comentar la realidad política y social imperante, aunque con una visión diferente a la de muchos de sus contemporáneos (Wamester-Bares 71).

De padre español y madre puertorriqueña, Tapia se mantuvo siempre fiel a España, a pesar de sus firmes ideas liberales y de su conocimiento de la naturaleza opresiva del régimen español (González-Pérez 25). No obstante, Tapia tiene reservas acerca de las relaciones de España con 
Puerto Rico, quejándose amargamente en sus memorias de la falta de representación de la Isla en la corte, y denunciando los frecuentes abusos de poder de los gobernadores enviados desde la Madre Patria.

Ya entrado el siglo XIX, la inestabilidad del gobierno español y los movimientos independentistas que surgen por todo el continente sudamericano debido a las injusticias políticas y sociales, a los problemas económicos y a las desigualdades culturales, repercuten inevitablemente en la Isla. Entonces, temeroso de que en Puerto Rico se desarrollaran semejantes ideas independentistas, el gobierno español nombra gobernantes cada vez más despóticos que rigen con mano de hierro (Picó 166).

A pesar de que Puerto Rico no logra su independencia en el terreno político, en el corazón de la sociedad puertorriqueña surge el anhelo independentista. ${ }^{13}$ Puerto Rico es una colonia española sin instituciones universitarias y sin recursos educativos que le permitan formar parte de la moderna edad científica y revolucionaria que comenzaba a despuntar en el diecinueve, por lo que, la aspiración de convertirse en una nación resulta un acontecimiento importante en la historia puertorriqueña.

Tapia forma parte de una generación literaria de puertorriqueños que responde a este complejo entramado histórico. El desarrollo de las letras

\footnotetext{
${ }^{13}$ En 1865, el entonces ministro de Ultramar, Antonio Cánovas, redacta un decreto mediante el cual los comisionados electos de Cuba y Puerto Rico eran invitados a exponer sus demandas ante la Junta Informativa de Reformas en Madrid. Luego de un año sin respuesta concreta a sus pedidos, el descontento en las colonias tuvo consecuencias inmediatas. En 1868, la Revolución de Lares en Puerto Rico, y la Revolución de Yara en Cuba, surgieron de la insatisfacción general. Si bien en Puerto Rico la revolución fracasó, Yara tuvo como consecuencia la Guerra de los Diez Años, antesala de la Guerra de 1898 (Benítez Rojo 12).
} 
puertorriqueñas nace al influjo del romanticismo español a fines de la primera mitad del siglo XIX (1842-1849), cuando un grupo de estudiantes puertorriqueños residentes en España se familiariza con el movimiento a través de Larra, Mesoneros y Espronceda. Inspirándose en sus ideas cosmopolitas y liberales, estos jóvenes inician una tradición de escritura culta en Puerto Rico. ${ }^{14}$ En esta corriente se aprecia el subjetivismo, el pesimismo, la duda, la rebelión individual y el predominio de la pasión. En su forma, vemos mayor libertad artística que la permitida por el neoclasicismo, el abandono de las tres unidades clásicas en el teatro, la mezcla de prosa y verso, y la renovación poética a través de una mayor expresión figurada. Además, habría que incluir la prosa periodística de quienes, a pesar de las limitaciones gubernamentales, hacen "alarde de una auténtica rebeldía romántica" (Rivera de Álvarez 59).

En 1849, Tapia es desterrado a Madrid a causa de un duelo con un oficial de artillería, y durante su expatriación tiene la oportunidad de reunirse asiduamente con los puertorriqueños que allí residen. Estos deciden estudiar las necesidades de Puerto Rico "tan olvidado y poco conocido entonces de la Metrópoli" (Tapia, Memorias 175). Cuenta Tapia que no podía hallarse ni

\footnotetext{
${ }^{14}$ Cabe señalar que en Puerto Rico los movimientos literarios siempre llegaron tarde, en gran parte debido al aislamiento en el contacto con otros pueblos; además, la imprenta llegó en el siglo XIX (1806), cuando ya era harto conocida en Santo Domingo y Cuba. A pesar de esto, "en la Isla se colaban de contrabando libros de Rousseau, Goethe, Byron, Montesquieu, Mme. Staël, Lamartine y Víctor Hugo, entre otros" (Rosa-Nieves, Plumas 85-86). La lectura de estas obras hizo que Tapia tomara "suma afición al drama histórico romántico, con sus grandes contrastes y sombrías pasiones", lo cual le hizo olvidar "que era hijo de una colonia española en la España monárquica" (Tapia, Memorias 152-53).
} 
siquiera un periódico que tratase de las cuestiones de Ultramar "ni diputado que a ellas consagrase algo de su tiempo". ${ }^{15}$ Por tal razón, los jóvenes isleños decidieron formar una sociedad recolectora de documentos históricos de Puerto Rico, cuya meta era la abolición de la esclavitud y la derogación de las leyes de limpieza de sangre (Tapia, Memorias 175). De ahí obtiene Tapia las fuentes para su Biblioteca histórica de Puerto Rico (1854), obra que "recogió las fuentes documentales más importantes de la historia de la isla" e "inauguró la historiografía científica de la segunda mitad del siglo XIX" (Benítez Rojo 8). Sus dramas históricos Roberto D’Evreux (1848), inspirado en el romance de Isabel I y el Duque de Essex, Camoens (1868), acerca del amor entre el poeta portugués y Catalina de Ataide, y Hero y Leandro (1872), además del libreto para la ópera indigenista de Felipe Gutiérrez, Guarionex (1854), le permiten tocar temas e ideas controversiales sobre la libertad política, los prejuicios raciales, el colonialismo y la opresión hacia las mujeres, amparándose en la distancia histórica y geográfica en la que se desarrollan estas obras, y protegiéndose así de la censura española (Paravisini-Gebert 1).

No obstante, la obra tapiana gana el calificativo de evasiva o escapista ya que en su mayoría se desarrolla en escenarios extranjeros y trata temas

\footnotetext{
${ }^{15}$ Irónicamente, Benito Pérez Galdós sería elegido diputado por Puerto Rico en 1886; este nunca visitó la Isla, y tan solo utilizó su cargo para conocer de cerca y estudiar la vida política española. En una comunicación epistolar Galdós indica que: Yo no soy ni seré político. He ido al Congreso porque me llevaron... Ya dentro del Congreso cada día me alegro de haber ido, porque, sin mezclarme en nada que sea política activa, voy comprendiendo que es imposible... conocer la vida nacional sin haber pasado por aquella casa" (Bravo-Villasante 131).
} 
ajenos a la realidad puertorriqueña de la época. Muchos de sus primeros críticos rechazan sus obras, en especial sus novelas, por considerarlas imitaciones de obras románticas europeas, alejadas de la realidad colonial de Puerto Rico. Antonio S. Pedreira, el destacado autor de Insularismo, opina que "sus dramas y novelas más importantes no tienen la sazón de nuestra biología y nuestra geografía" (61-62) ${ }^{16}$ Por su parte, Rosa-Nieves y Franco Oppenheimer opinan que "tal vez, por su afán romántico de darle la vuelta al mundo tan de prisa, no profundizó Tapia lo que debió ahondar en su tierra... él que fue un corazón tan profundamente puertorriqueño" (27).

No obstante, José Juan Beauchamp observa que esa predominante "tendencia evasiva" puede deberse al miedo a la censura y la pasión por lo exótico que caracteriza el romanticismo en Europa (32). Mas no podía ser de otra manera, ya que Tapia y Rivera fue "acosado por la censura gubernamental desde sus comienzos de escritor" (Rivera de Álvarez 18). Una estricta censura gubernamental para libros y periódicos reinaba en la Isla. La publicación más asequible y constante era La gaceta del gobierno (18061902), un mosaico de publicidad, edictos, alabanzas al monarca español, y tal vez algún poema de menor importancia. Recordemos que la expresión literaria puertorriqueña fue una de las últimas en florecer dentro del ámbito hispano; no tiene verdadera esencia artística ni verdaderas raíces hasta ya entrado el siglo XIX. Simplemente se mantiene ligada a la literatura española

\footnotetext{
${ }^{16}$ En Insularismo (1934), Pedreira explora lo que significa ser puertorriqueño a la luz de la integración de las culturas española, indígena y africana que dejan una profunda huella en la Isla. También habla de la persistencia cultural de la identidad puertorriqueña luego de la invasión estadounidense.
} 
y se limita la expresión del escritor isleño debido a las circunstancias políticas y culturales (40-41). Manrique Cabrera apunta que "su primera obra de empeño... Roberto $D^{\prime} E v r e u x "$, fue un drama cuya representación y publicación prohibió la censura oficial porque "en las provincias de América no debía permitirse la impresión ni representación de obras en que se humanizase a los reyes" (115).

Durante su exilio Tapia entro en contacto con el movimiento krausista, fundado en Alemania por Karl Krause e introducido en España por Julián Sanz del Río y Francisco Giner de los Ríos. El ldeal de la humanidad para la vida de Krause, que fue utilizado por los krausistas como guía político-moral durante la época, plantea esta ideología reformista y humanitaria. Tapia llega a conocer, además, las corrientes positivistas y materialistas del siglo XIX y las ideas esotéricas de esta época. ${ }^{17}$ Se interesó también por las prácticas espiritualistas que para entonces se habían puesto tan de moda. ${ }^{18} \mathrm{De}$ acuerdo con Menéndez Pelayo, entre 1868 y 1878, se publicaron en España numerosos libros y folletos sobre el tema espiritista. La novedad de esta creencia consiste en haberse "enlazado con la doctrina de la transmigración

\footnotetext{
${ }^{17}$ En Puerto Rico surgen escritores espiritualistas respetuosos de esta doctrina. Manuel Corchado Juarbe y Rosendo Matienzo Cintrón, ambos contemporáneos de Tapia, se sirvieron del sustrato esotérico para estructurar su obra narrativa con una finalidad edificante, instructiva y moral.

${ }^{18}$ Utilizando los elementos del "espiritismo" como estrategia literaria, "Tapia retrata a un sujeto moderno disfuncional que se derrumba oprimido por el absurdo de las convenciones sociales y el sistema burocrático. (Saldivia-Berlung 42).
} 
de las almas y con ciertas hipótesis astronómicas" (221). ${ }^{19}$ Estas ideas fueron diseminándose por toda Europa mediante traducciones de obras como Lumen (1872), de Nicolás Camille Flammarion (1842-1925), una serie de cinco diálogos entre un alma desencarnada y su interrogador humano sobre la física y la metafísica de la vida después de la muerte. Aparte de estas lecturas también circulaba el emblemático Libro de los espíritus (1857) de Allan Kardec (1804-1869), donde se tratan los temas de la creación, la encarnación de los espíritus y las leyes divinas, entre otros. Alicia Cerezo Paredes señala que a diferencia de las historias de fantasmas, en España, los cuentos espiritistas no son considerados ficción. Es preciso aclarar que, mientras los románticos experimentan una profunda angustia como resultado de los conflictos entre su idealismo y realidad, o entre sus valores personales y los de la sociedad, los espiritistas ven estas dualidades como algo natural, incluso como una simbiosis necesaria. Para los espiritistas la presencia de fantasmas es casi siempre tranquilizadora. Se piensa que vienen a guiar a los vivos, a menudo en un sentido pedagógico. Dado que para los

${ }^{19}$ Ahondando en el tema de la reencarnación, Menéndez Pelayo cita a D. Juan Alonso Eguílaz, quien describe las transiciones del alma:

[el alma] necesita realizar la infinidad de estados que como potencia inagotable contiene, y esto sólo puede verificarse en un tiempo infinito... De aquí que los hombres todos, en colectividad y sin distinción, pasen después de morir, a otro mundo y a otro período de vida, con condiciones mejores y más favorables, perfeccionándose físicamente sus cuerpos asimismo sus almas. El principio de la transmigración es el que rige esta elevación y este ennoblecimiento progresivo del universo... Los hombres todos procedemos, por consiguiente, de verificaciones pasadas, en que, bajo formas más humildes, nos hemos ido capacitando para alcanzar el grado de dignidad en que nos encontrarnos. (Historia de los heterodoxos españoles, Libro VIII 208) 
espiritistas, los límites entre este mundo y el más allá están lejos de ser fijos, los fantasmas forman parte de la realidad cotidiana (8).

Por último, no debe olvidarse otro aspecto importante en la formación filosófico-literaria de Tapia, y muy relevante para el presente estudio: la filosofía idealista hegeliana. ${ }^{20}$ Hegel plantea que el universo se encuentra en constante cambio, y todo tiende a convertirse en su opuesto. El choque con lo opuesto termina en una fusión que crea un nuevo ente. A partir de estas ideas, Tapia señala que "el objetivo... de la actividad humana ni debe ser otro que el perfeccionamiento del hombre como ser individual y social, destinado a fines tan misteriosos como espirituales y universales" (Conferencias 190). Dentro de este contexto, Tapia hace uso de su obra literaria para formular su objetivo ético.

Por otra parte, si echamos un vistazo a la obra galdosiana dentro del contexto europeo, veremos cómo muchas de estas ideas centrales repercuten en su obra. Benito Pérez Galdós representa la figura máxima del realismo español y, sin duda, se identifica con el mencionado periodo por su vocación y su decisión consciente de estudiar los problemas sociales de

\footnotetext{
${ }^{20}$ Alejandro Tapia y Rivera señala en sus Conferencias sobre la estética (1881), que "la creencia de lo bello entró en la esfera filosófica con Kant... toda vez que aquel padre de la filosofía germánica, aplicándola [sic] su sistema, sólo consideró lo bello subjetivamente, es decir, como idea abstracta” (24). Además, Tapia y Rivera señala que el sistema metafísico de Hegel "su filosofía del espíritu, su filosofía de la naturaleza y demás obras, [son] verdaderos prodigios en que al través de sus brumosos tecnicismos se perciben verdades grandiosas, no pueden menos de inspirar respeto" (26-27). Más aún, Carlos Rojas Osorio, en su Esquema histórico de la filosofía en Puerto Rico señala que "Tapia también usa una expresión más amplia: la realidad es la expresión sensible de la idea. Lo que significaría una adhesión a Hegel más allá de la estética" (2).
} 
acuerdo con los principios básicos de esta tendencia literaria (García López 564). ${ }^{21}$ No obstante, el realismo como movimiento literario del siglo XIX, "no constituye una expresión de principios uniformes e invariables, sino que se manifiesta... en diversidad de grados y modulaciones" (Correa 7).

Ciertamente, Galdós estudia varios niveles del mundo de la realidad que poco a poco revelan áreas ocultas de la naturaleza humana y de la conciencia individual. Es decir, que el realismo galdosiano "se dirige, de esta manera hacia una exploración de la persona como centro irradiante de comunicación con el mundo exterior" (9). ${ }^{22}$

${ }^{21}$ Galdós inicia pronto su actividad como periodista y novelista, siendo de gran importancia el viaje que realiza a París en 1867 para visitar la Exposición Universal. Allí entra en contacto directo con la gran narrativa francesa, y en particular con la obra de Balzac. A su regreso a España comienza a escribir su primera novela importante, La fontana de oro, y ya en 1866 había comenzado La sombra. Sin embargo, la primera se publica en 1870 y la segunda en 1871. En 1873 inicia el que será su ciclo histórico de los Episodios Nacionales. En solo dos años completa la primera serie, desde Trafalgar hasta La batalla de los Arapiles, para continuar la segunda serie y luego escribir veinte novelas en un plazo de siete años. También escribe y publica varias obras narrativas hasta completar las que la crítica ha llamado novelas de la primera época: Doña Perfecta (1876), Gloria (1877), Marianela y La familia de León Roch (ambas de 1878). La desheredada, que comienza en 1880, inaugura una nueva etapa galdosiana influida por el naturalismo. Será la primera de la serie de "novelas españolas contemporáneas" que se compone de veinticuatro obras: El amigo Manso (1882), El doctor Centeno (1883), Tormento, La de Bringas (ambas en 1884), Fortunata y Jacinta (1886-1887) y Ángel Guerra (1890-1891) entre otras. Hacia 1892 empiezan sus primeros éxitos como dramaturgo con el estreno de Realidad y de La loca de la casa al año siguiente, protagonizadas ambas por María Guerrero, la actriz más famosa del momento. Su triunfo más resonante lo alcanza con Electra en 1901. Además de otra nueva serie de Episodios nacionales, se suceden las publicaciones de algunas de las novelas más importantes de su última época: Nazarín y Misericordia, que consolidan definitivamente su fama (Gutiérrez Díaz-Bernardo 10-11).

${ }^{22}$ Su filosofía parte de la de Sanz del Río y su concepción de la psique humana va de la mano de William Wundt y no Taine o Spencer. Si se acerca al positivismo es para abandonarlo en seguida y pasar de Comte a Hegel. Todo en él señala la tendencia a la armonización de los contrarios (Oleza 3). 
La obra galdosiana es mayormente urbana, tanto en el ambiente como en el punto de vista. Luego de estudiar en la Universidad de Madrid en 1862, a la edad de diecinueve años, Benito Pérez Galdós vivirá en la capital para el resto de su vida, volviendo a su natal Canarias solo una vez después de 1869. Madrid es el escenario de todas sus novelas de 1878 a 1889 , y de la mayoría de sus novelas contemporáneas en general (Labanyi 3). Algo que ya había notado su contemporáneo, Leopoldo Alas, cuando observa que: "De lo que no hay ni rastros en sus novelas es del sol de su patria; ni del suelo, ni de los horizontes;.. jamás ha escrito nada que pueda hablarnos de los paisajes de su patria; no sueña con el sol de sus islas" (16).

Sherman Eoff nos recuerda que es importante pensar en Galdós como un español que se encuentra en un entorno español, y que ha dejado un registro inolvidable de la sociedad. ${ }^{23}$ No obstante, también nos dice que hay otra manera de encontrar una base sólida sobre la que puede valorarse a Galdós: un europeo del siglo XIX; y es que Galdós fue, en gran medida, un ciudadano de Europa tanto como de España. Su afinidad con ciertos escritores europeos es bastante conocida, y cuando comparamos a Galdós con otros grandes escritores de su época, podemos ver claramente que su

\footnotetext{
${ }^{23}$ Eoff señala que Galdós se propuso mostrar el significado del concepto de "patria" y el creciente protagonismo de una nueva clase media; todo esto lo hizo siguiendo una técnica propia del folletín, consistente en ir narrando los sucesos históricos como "novelas históricas breves y amenas" a través de las diversas personificaciones de un joven de origen humilde, y que algunos críticos denominaron episodios "oficiales" por su defensa de los principios patrióticos de la Restauración. En ellos exalta el papel de la clase media, un pueblo unido para defender a la patria. Galdós busca en fuentes históricas para informarse, acude incluso a testimonios de supervivientes, y toma de la historia lo anecdótico, lo asequible.
} 
personalidad literaria se encuentra marcada por lo que podría llamarse el espíritu literario del siglo XIX ("Galdós in Nineteenth-Century" 2). El idealismo de Galdós revela una afinidad general con el krausismo de Sanz del Río en la creencia de la unidad de Dios con todas las cosas, en una relación donde las partes, aunque en oposición entre sí, forman un conjunto armonioso (Eoff, The Novels 133). ${ }^{24}$

Ricardo Gullón ha visto en el arte de Galdós una variedad de perspectivas que sin duda trascienden los presupuestos comunes de la escuela realista en su visión específica, pero también intenta superar o reinterpretar estos mismos presupuestos, y la influencia que ejercen sobre la humanidad. Galdós era extremadamente metódico, observador, atento y callado, "apenas tomaba notas... pero solía dibujar los rostros y figuras de los seres imaginarios y esos dibujos los colocaba ante sí mientras escribía. Novelaba rápidamente porque la vena creadora descansaba sobre dos aptitudes admirables: memoria vivificante e imaginación" (19).

Galdós nunca aceptó plenamente el naturalismo determinista de Zola, aunque lo reprodujo tanto en sus personajes como en la realidad exterior a estos con "una precisión casi clínica" (Crow 266). Pero Galdós no veía la conciencia individual como algo determinado por el entorno físico. Les dio a sus personajes libre albedrío, uno de los principios básicos del catolicismo y,

\footnotetext{
${ }^{24}$ El krausismo "se caracterizó por un espíritu de armonía, un culto a la ciencia, una austeridad ética y moral y por una actitud de libre examen" (De Jongh-Rossel 192). La libertad de conciencia trajo consigo una tolerancia hacia toda doctrina y la convicción de que la razón se impone al dogma. Atrás dejaron los krausistas el absolutismo intelectual, social y religioso, para promulgar una reforma que armoniza las instituciones humanas con Dios y con la Naturaleza.
} 
de la filosofía hegeliana. La personalidad individual en las novelas de Galdós adquiere la forma de un conflicto entre el "yo", por un lado, y los "otros" con los que el crecimiento individual, a través de su relación con los demás, se encuentra con muchos tipos diferentes de "otredad", y con cada encuentro su personalidad se ve alterada. La relación que comienza como una lucha de contrarios, termina en una especie de fusión (266). No sería de extrañar entonces que Galdós implementara este conocimiento a la hora de crear sus tramas y personajes como bien señala James $\mathrm{H}$. Hoddie: "My own readings suggest that, more than likely assisted by a rather thorough reading of Hegel's aesthetics, Galdós exercised care in the application of the latter's theories as well as his own ideas and observations" (401). ${ }^{25}$

Hazel Gold, por su parte, afirma que Galdós es el novelista más innovador y profundo de la España del siglo XIX, y es quizás el mejor ejemplo de lo que es un escritor español situado en la frontera entre la novela realista y la novela moderna; muestra además, una aguda comprensión de las formas en que la experiencia tanto histórica como literaria está estructurada: Galdós crea narrativas que, en sus formas paradójicas y a veces transgresoras "either undermine or flatly negate many of the restrictive conventions of so-called high or orthodox realism" (2). Y es a propósito de estos planteamientos de Gold, que José Schraibman observa cómo Galdós

\footnotetext{
${ }^{25}$ En el siguiente pasaje de El amigo Manso, puede verse al personaje principal haciendo referencia directa al estudio hegeliano; "Estaba yo aquella mañana poniendo notas y prólogo a una traducción del Sistema de Bellas Artes de Hegel, hecha por un amigo. Las ideas sobre lo bello llenaban mi mente y se revolvían en ella, produciéndome ya tal confusión, que la vista de aquella señora fue para mi pensamiento un placentero descanso" (Galdós 384).
} 
define e interpreta las estructuras del liberalismo burgués español, aunque estas estructuras no conducen a un final cerrado, sino abierto y cambiante. Esto hace que el lector pueda interactuar con los elementos de la obra. De esta manera "cuestiona tanto el marco narrativo como su lenguaje, problematizando la representatividad de su supuesto realismo" (4).

Ciertamente, la realidad desempeña a primera vista el papel central en la obra del autor, mas luego de analizar esa realidad representada en la novela galdosiana deben puntualizarse las contribuciones que a esta ha hecho el don visionario que supone la capacidad de descubrir las realidades más recónditas que habitan bajo la apariencia. De esta forma, observa Gullón, puede captarse aquello que queda invisible y que constituye la llave de los secretos del alma, "de manera tan sencilla que su misma claridad y sencillez quite todo eco tenebroso de lo narrado. Galdós poseía el don visionario" (169). Debe tenerse en cuenta que, a pesar de poseer tan extraordinarios poderes de observación, en Galdós pesa más la imaginación: Hay un mundo oscuro, un mundo del que no tenemos conciencia exacta ni podemos tenerla a través de la razón y del examen lógico de acontecimientos y situaciones. Tal mundo está integrado en el orbe novelístico galdosiano, con todos sus caóticos elementos: es el mundo de lo inexplicable, de lo maravilloso. Y esos elementos, imbricados fuertemente con los procedentes de la realidad, forman parte del orbe total y 
contribuyen a conferirle la autenticidad y la plenitud con que le encontramos. (Gullón 169)

En ese mundo de lo insondable se cuelan sueños, alucinaciones, insomnio y criaturas extrañas, fantasmas que deambulan en un plano diferente, loco, alterado, extraño. Todo lo que no es la vida ordinaria es apenas perceptible, pues los fenómenos y seres más característicos de esa zona, no pueden explicarse mediante los métodos conocidos de análisis porque "en Galdós los elementos maravillosos, lo irreal y fantástico surge fundido con la realidad, y en la mayoría de sus novelas lo encontramos, pero no en estado puro... sino, en la dosis y medida con que la realidad los depara" (171).

En cuanto al tema de lo fantástico, Timothy McGovern plantea que la crítica todavía sostiene una larga polémica respecto a los textos de carácter no realista o fantástico de Galdós. En primer lugar, estas obras han sido a menudo relegadas por la crítica a un segundo plano dentro del canon galdosiano, debido a la extrema importancia que muchos especialistas otorgan a las expresiones realistas y racionalistas de su obra. En segundo lugar, incluso cuando hay un consenso sobre el trasfondo artístico de sus obras, muchos de estos textos han inspirado acaloradas discusiones sobre su naturaleza experimental-sobrenatural: "some critics have either completely ignored the magical events and characters into a realist framework, demanding that these be read as either symbolic gestures on the part of Galdós, or that they simply be interpreted as dreams on the part of the characters" (11). La manera en que estas creaciones literarias pueden 
aislarse y analizarse en su conjunto, y luego volver a insertarse en el canon de Galdós, lleva a McGovern a identificar lo que denomina las "novelas mágicas" galdosianas o aquellas en las que sucesos y personajes sobrenaturales invaden el paisaje de la narración.

A nuestro juicio, estos acontecimientos sociales, filosóficos y literarios, ejercen una profunda influencia en la literatura de la época, y nos ayudan a comprender las obras de Alejandro Tapia y Rivera y Benito Pérez Galdós que analizaremos en el presente trabajo. 


\section{CAPÍTULO II}

Bajo el influjo del "Sturm und Drang"

The common end of all narrative, nay, of all, Poems is ... to make those events, which in real or imagined History move on in a strait Line, assume to our Understandings a circular motion - the snake with its Tail in its Mouth.

Samuel Taylor Coleridge

El pensamiento y la literatura romántica representan un giro decisivo en la cultura occidental. Los escritores de la época reinterpretan su patrimonio cultural y desarrollan nuevas formas de experimentar el mundo exterior, la naturaleza, la historia y un nuevo conjunto de relaciones que el individuo desarrolla consigo mismo y con sus semejantes. En la llamada filosofía romántica, se retienen los conceptos cristianos tradicionales y la trama tradicional cristiana, pero desmitificando y conceptualizando la divinidad, la cual se convierte en una "lógica" o dialéctica que controla todas las interacciones entre sujeto y objeto (Abrams, Natural Supernaturalism 14, 91).

Las raíces del romanticismo se remontan al movimiento alemán llamado "Sturm und Drang" (Tempestad y Pasión), el cual se aleja de las reglas clásicas, concediéndole importancia a la expresión del mundo interior del artista. ${ }^{26}$ Esta filosofía marca el comienzo de una visión panteísta que ve la divinidad reflejada en la Naturaleza. Durante la mayor parte del siglo XVIII, la ilustración y el movimiento prerromántico consideran la razón como una

\footnotetext{
${ }^{26}$ El nombre de "Sturm und Drang" (Tempestad y Pasión) proviene de la pieza teatral del mismo nombre, escrita en 1776 por el dramaturgo alemán prerromántico Friedrich Maximilian Klinger (1752-1831).
} 
fuerza finita, mientras que el idealismo ve en esta una fuerza infinita, capaz de conocer la totalidad, lo absoluto. El arte y la poesía se convierten en medios que unen emocionalmente al hombre con esta Naturaleza sacralizada (Stuckrad 109-10). La concepción mecánica del mundo se sustituye por una visión orgánica o dinámica, y comienza a verse la Naturaleza como algo espiritual, que debe interpretarse de manera teleológica, es decir, atribuyéndole una finalidad u objetivo a sus procesos. En definitiva, lo que el idealismo alemán persigue es restablecer la función de la mente en el ámbito de lo natural, deduciendo que todo lo que constituye el mundo de la realidad procede de una sola "idea" absoluta (Kelly 57). Así, esta nueva tendencia filosófica se opone a la llustración y sus postulados, constituyéndose en precursora del movimiento romántico (Abrams, Mirror 9091).

Conviene recordar que fue Immanuel Kant el primero en reconciliar los elementos conflictivos empíricos y racionales de la filosofía dogmática, esa filosofía que utiliza la razón con la pretensión de alcanzar con ella un conocimiento de las realidades trascendentales, de las realidades que están más allá de nuestra experiencia. Kant intentó demostrar que aunque no podemos confiar del todo en los sentidos para conocer la realidad, estos nos informan acerca de cómo se nos representa el mundo. Según Kant, todo nuestro conocimiento comienza con la experiencia, puesto que nuestra facultad cognoscitiva se despierta por medio de los sentidos, los cuales producen representaciones que estimulan nuestros poderes para comparar, 
conectar o separar. Nuestras sensaciones entonces se convierten en el conocimiento de los objetos, y es eso a lo que llamamos "experiencia". Entonces, de acuerdo con esta interpretación kantiana expuesta en la Crítica de la razón pura, ningún conocimiento antecede a la experiencia, sino que comienza con esta (1). No obstante, aunque los seguidores de Kant adoptaron muchas de sus ideas, pensaban que este no ofrecía una explicación coherente que unificase mente, naturaleza y moral.

Hegel respondió a este dilema sugiriendo que las contradicciones insolubles expuestas por Kant eran aplicables no solo a las áreas que Kant mismo demostró, sino también a todo objeto y concepción, noción e idea. Hegel presentó su filosofía en términos metafísicos. El conocimiento y la acción moral eran aspectos de la estructura de la realidad. Como bien señala Abrams, "his starting point is the state of 'immediate knowledge', which is a unitary act of simple perception, free of all conceptualization, hence of any distinction between subject and object" (Natural Supernaturalism 232).

La filosofía hegeliana en particular, propone que el conocimiento humano se basa en la "Idea", un concepto en el que se funden la naturaleza y el espíritu. Como ya hemos visto, Hegel deriva su filosofía de las categorías de conocimiento concebidas por Kant, las cuales daban forma a la realidad. Para Hegel, sin embargo, las categorías continúan cambiando y tienden a entrar en conflicto unas con otras. Hegel acepta el idealismo de Kant y ve la realidad como un producto de la actividad de una mente racional; no obstante, esta mente es una especie de espíritu universal (Geist) que se 
mueve a través del tiempo y del espacio. De esta manera, Hegel siente que, a través de un método de pensamiento radicalmente nuevo, ha hecho "Kant's noumenal realm present: what things-in-themselves are is the Absolute or Unconditioned... World, Soul, and God together" (Magee 154).

Dado que el pensamiento abstracto es limitado, Hegel considera cómo las formaciones históricas dan pie a diferentes filosofías y formas de pensamiento. Para Hegel, el pensamiento falla cuando solo se le da una abstracción y no se une a consideraciones de la realidad histórica. En su obra principal, La filosofía del espíritu, explora la formación de la conciencia propia a través de la historia y la importancia de otros entes en el despertar de la conciencia propia. Por lo que introduce dos importantes ideas a la metafísica y a la filosofía: la importancia integral de la historia y la importancia del "Otro" (Magee 9).

Para Hegel, el "ser" es un buen ejemplo de una tesis. La antítesis del ser es la "nada". De esta manera, el ser y la nada resuelven sus diferencias mediante una síntesis o un proceso de "conversión". Este proceso lo vemos en la historia del pensamiento humano, y está dirigido hacia una experiencia universal de conocimiento propio en la cual la realidad se reconoce y se libera. Hasta entonces, la humanidad experimenta sufrimiento y aislamiento a causa de la fragmentación de las ideas. Un ejemplo de este aislamiento es la idea de que es imposible conocer a Dios, ya que es un ente separado de la humanidad. Ya que los seres humanos creen en un dios que está separado 
de ellos, se sienten desconectados de la realidad en vez de formar parte integral de esta.

Hegel concluye la historia es el desarrollo continuo de la "Idea Absoluta" por medio de un proceso dialéctico: una tesis genera una antítesis y por contraposición, una síntesis totalizadora. Es decir, las contradicciones en el espíritu universal pueden entenderse como dos caras de una misma discusión (argumento): tesis y antítesis que se resuelven en una síntesis. Este proceso continúa hasta que todas las contradicciones del espíritu se resuelven entre sí. Al llegar a este punto final de la historia, Hegel piensa que el espíritu ha adquirido completo conocimiento de sí, es decir, que esto solo es posible en este momento particular, "when the philosophical, cultural and religious achievements of the ages were spread out before his gaze" (Magee 127).

El romanticismo puede comprenderse mejor si se contrasta con el movimiento neoclásico. En esencia, mientras que el neoclasicismo da importancia a la racionalidad humana, el romanticismo reevalúa la esfera del sentimiento, la pasión y hasta la irracionalidad. El arte se convierte en la expresión de un mundo interior que debe estudiarse en profundidad. Uno de los rasgos románticos más característicos es la revalorización de la parte instintiva y apasionada del hombre. Esta tendencia lleva a buscar lo oscuro y sombrío, el misterio, la emoción, el horror y el terror. El artista comienza a actuar cada vez más en una forma no convencional, en algunos casos, indudablemente asocial y amoral. Y es que el hombre del siglo XIX se 
encuentra atrapado en un mundo que resulta demasiado materialista y aburrido. En la Edad Media, la existencia de demonios, monstruos y fantasmas se aceptaba sin discusión, y los románticos sienten nostalgia por una época que resulta mucho más estimulante para la imaginación que los ferrocarriles y los barcos de vapor (Wilson 374-75). Pero el romanticismo es mucho más que una corriente literaria, es una visión de mundo, una filosofía más que una manera de enfrentarse a la vida. Abarca todos los aspectos de la cultura de la época, desde la política hasta el arte, la literatura y las modas, porque en el fondo viene a constituir una actitud especial frente a la vida.

El neoclasicismo es profundamente secular e incluso ateo, el romanticismo por su parte, es un movimiento de grandes influencias religiosas. El artista romántico es un personaje fundamentalmente pesimista. Vive su sufrimiento psicológico con gran dramatismo. El arte romántico redescubre la esfera religiosa, después de un siglo, que fue esencialmente secular y anticlerical. En el neoclasicismo se toma como referencia la historia clásica, el romanticismo, sin embargo, hace una reevaluación de la Edad Media que, hasta entonces, había sido considerada una época oscura y bárbara. Finalmente, si la práctica neoclásica impone en lo artístico las reglas y el método, la inspiración romántica revalora la chispa y el genio individual. Debe tenerse en cuenta también que el estilo neoclásico es internacional, y reniega de expresiones de folklore local, mientras que el romanticismo se place en presentar las características típicas de cada país. 
El romanticismo español, por su parte, llegó tarde y se prolongó durante un corto período de tiempo. El período romántico abarca un momento de alta tensión política. Los conservadores defendían sus privilegios, pero los liberales y los progresistas luchaban por derrocarlos. Esto abre el camino para que los laicos y la masonería disfruten de una gran influencia. La tradicional iglesia católica se defiende contra los librepensadores y los seguidores del krausismo. El krausismo en España se convierte, no en una doctrina filosófica, sino en una guía ética y un modelo para un estilo de vida guiado por la razón. Mientras Europa experimenta un significativo desarrollo industrial y cultural, España se presentaba como un país retrógrado y separado del resto de Europa. El movimiento krausista pretende reformar una sociedad que, según sus propulsores, se encuentra en un estado letárgico, a causa del anquilosamiento de instituciones tradicionales que en nada adelantaban el progreso de la sociedad española. El filósofo alemán Karl Christian Friedrich Krause ---quien estudió filosofía con Friedrich W. Schelling, Hegel y Fichte --- desarrolló un sistema filosófico introducido en España a mediados del siglo XIX por Julián Sanz del Río, profesor de filosofía en la Universidad de Madrid. Sanz del Río declaró en su discurso inaugural del año académico de 1857-1858, en la Universidad Central que:

El materialismo del siglo XVIII, dolorosa expiación de anteriores pecados, no ha desmoralizado la sociedad con la fuerza de la Filosofía, sino con fuerzas extrañas y de antiguo viciadas, que 
dieron falsa vida a doctrinas indignas de la Filosofía científica, y en las que buscó aquel siglo degradado una autorización al desenfreno de cortes y grandes, ejerciendo sobre la Ciencia, como sobre la Religión y la Moral, la presión corruptora de las costumbres sociales. (7)

En fin, el krausismo proporciona a los intelectuales liberales una alternativa a las filosofías europeas modernas, que carecían de un componente espiritual, al tiempo que les permite distanciarse de la Iglesia católica (López-Morillas $34)$.

Muchos intelectuales europeos rompen relaciones con las grandes iglesias (católicas, protestantes y judías) para adentrarse de manera personal en el terreno de lo divino. La manifestación idealista de la filosofía alemana del final del siglo XVIII y principio del XIX lleva a un esoterismo panteísta. Y tanto los sistemas de pensamiento de Hegel como Fichte y Schelling fueron convirtiéndose en "logosofías" en las que Dios se identifica con el pensamiento individual del hombre en forma de "secreto" intelectual, propio de iniciados. En esta coyuntura, creemos importante repasar el origen de la tradición hermética, de trascendental importancia para nuestro estudio, la cual también deja su huella en la ideololgía del siglo XIX.

De todas las tradiciones espirituales conocidas en Occidente, la de Hermes Trismegisto, puede considerarse como una de las más antiguas. Expuesta a alteraciones por el transcurso del tiempo, la tradición hermética se arraiga en el pasado egipcio más remoto. Cuando escuchamos el término 
"hermetismo" o su adjetivo, "hermético", nos viene a la mente algo impenetrable, cerrado, oculto. Este significado viene de la palabra latina "hermeticus", que de acuerdo al diccionario tiene su origen en "las especulaciones, escritos y partidarios que en distintas épocas han seguido ciertos libros de alquimia atribuidos a Hermes" en directa referencia al legendario Hermes "Trismegisto". A partir de aquí surge una escuela de pensamiento fundamentada en una serie de doctrinas religiosas y tradiciones filosóficas basadas principalmente en escritos atribuidos a este legendario personaje, conocido como el padre de la sabiduría oculta, fundador de la astrología y descubridor de la alquimia. De hecho, los primeros herméticos sostenían que el poder que conllevaba el acceso a los conocimientos de la doctrina, debía protegerse de aquellos que no fueran capaces de comprender la responsabilidad que conllevaba utilizar estos conocimientos.

En la visión hermética, el cosmos es una entidad viviente y todo en él está lleno de vida, ya que el universo es Dios y Dios es el universo. También incorpora la idea platónica de anima mundi, esa conexión intrínseca entre todos los seres vivos en el planeta, como vemos en este pasaje del Poimandres:

¡Tú eres todo y no hay nada que no seas Tú! Tú eres todo lo que ha nacido y todo lo que no ha nacido, la inteligencia pensada, el Padre Creador, el Dios Hacedor, el Bien y el Autor de todas las cosas. Lo que hay más sutil en la materia es el 
aire, en el aire el alma, en el alma la inteligencia, y en la inteligencia Dios. (Los libros de Hermes Trismegisto 90)

Por tanto, eso que llamamos "sobrenatural" o "paranormal" no es sino parte de la naturaleza misma. De acuerdo al hermetismo, Dios necesita crear para poder existir. Más aún, el ser humano desempeña un papel crucial en el reconocimiento que Dios hace de sí mismo. En términos generales, implica una búsqueda intuitiva más que racional, del conocimiento personal del alma y de Dios. Como resultado de la práctica hermética se eliminan las restricciones terrenales y cósmicas para llegar a una unidad esencial con la divinidad mediante un conocimiento o gnosis. El ser humano es una conexión, un puente entre el espíritu y la materia, es, en esencia, las manos, los dedos de Dios que van palpando la faz del mundo material y llevando la información adquirida desde el plano físico hasta el espiritual.

A primera vista, los textos herméticos parecen un conjunto heterogéneo de escritos. Algunos de estos son textos teológico-filosóficos, y otros tienen un contenido mágico, astrológico o alquímico. De acuerdo con Frances A. Yates, el hermetismo surge de una serie de doctrinas religiosas y tradiciones filosóficas, basadas principalmente en escritos atribuidos a un legendario sacerdote egipcio, conocido como el padre de la sabiduría oculta, fundador de la astrología y descubridor de la alquimia. Se cree que los egipcios lo convirtieron en dios y lo llamaron Tot, escribano de los dioses. Mucho tiempo después, los griegos le dieron el nombre de Hermes, conocido también como "Trismegisto", es decir, "tres veces grande". Luego los 
romanos se apoderan de esta descripción y lo asocian con Mercurio, el mensajero de los dioses. Señala Cicerón en su De natura deorum que en realidad había cinco Mercurios, y que el quinto huyó a Egipto para darles a los egipcios sus leyes y cartas y adoptó el nombre egipcio de Theuth o Tot.

A pesar de centrarse dentro de un marco de carácter seudo egipcio, muchos teóricos opinan que estas obras contienen muy pocos elementos egipcios. Como quiera que sea, tanto la figura como los escritos de Hermes Trismegisto fueron el producto del sincretismo filosófico helenístico de la naturaleza, que a su vez era un conglomerado de doctrinas aristotélicas, platónicas, estoicas y pitagóricas, intercaladas con motivos de la mitología egipcia y temas de origen judío y persa (Yates 2).

En Grecia se desarrolló una amplia literatura sobre astrología y ciencias ocultas bajo el nombre de Hermes Trismegisto. Además de estos tratados o recetas mágicas, se desarrolló una escritura filosófica, a la cual también se le atribuyó al nombre de Hermes. Se desconoce el número exacto de textos herméticos, al igual que la identidad del propio Hermes Trismegisto, aunque existen muchas versiones al respecto. Tampoco se sabe exactamente cuándo comienza a utilizarse el marco hermético para temas filosóficos, pero es posible que el Corpus Hermeticum date de entre 100 y 300 E.C. (Yates 2).

Antoine Faivre, ha señalado que Hermes Trismegisto ocupa también un lugar de importancia en la tradición islámica, aunque no aparezca mencionado en el Corán. Los árabes asociaron a Hermes Trismegisto con 
Idris, descrito como un mensajero de dios o un profeta. ${ }^{27}$ Se dice que IdrisHermes escribió poemas, en particular odas, en árabe, hebreo y siríaco, por lo que por trasciende divisiones sectarias y misterios religiosos (19-20). Ya para el año 640 d.C, los árabes encontraron en Egipto manuscritos y tablas con inscripciones aparentemente herméticas. Los manuscritos árabes mencionan una edificación dedicada a Hermes en Memphis, en la que Hermes supuestamente fue enterrado. Para el siglo X, comienzan a circular las historias del descubrimiento de una tabla en la tumba de Hermes que contenía secretos alquímicos. El texto breve, pero muy célebre, de la Tabla de Esmeralda pertenece a esta literatura (Faivre 91).

En el judaísmo, la influencia hermética surgió en la Cábala. El breve y fundamental texto cabalístico Sepher Yetsirah (Libro de la Formación), siglo III d. C.?) expone una cosmología basada en la doctrina de correspondencias, especialmente la de los siete planetas, días de la semana, aperturas de la cabeza, etc. y la del dodecanato del zodíaco, las direcciones del espacio, los meses y los órganos del cuerpo. Describe un cosmos no desgarrado entre el bien y el mal, sino suspendido en la polaridad por energías positivas y negativas. El método de salvación es por medio de la toma de conciencia de uno mismo como microcosmos, sentando al "Rey en

\footnotetext{
${ }^{27}$ Idris es descrito en el Corán como "confiable" y "paciente", y que fue "exaltado a un alto nivel", lo que ha sido interpretado en la tradición islámica en el sentido de que ascendió al cielo sin morir. Debido a este y otros paralelos, Idris tradicionalmente se ha identificado con el Enoc bíblico, y por lo tanto la tradición islámica lo coloca en las primeras generaciones de Adán. Se dice que Mahoma se encontró con Idris en el cuarto cielo, y muchos místicos o sufíes musulmanes posteriores, incluyendo Ruzbihan Baqli e Ibn Arabi también mencionan haber encontrado a Idris en sus visiones espirituales.
} 
Su Trono" (la presencia divina) en el centro de la vida. De nuevo, tenemos una doctrina que afirma la Naturaleza y el cuerpo y están relacionados con la realización del macrocosmos en el microcosmos. La idea esotérica de Israel, es también una idea hermética: la de que los judíos están llamados a dar testimonio del orden divino en la tierra. Al igual que en el hermetismo, la tierra, incluyendo el cuerpo humano, está llena de influencias celestes, por lo que la forma de vida judía está diseñada para asegurar que toda acción conlleve un significado espiritual.

Muchos escritores cristianos como Lactancio, San Agustín, Giordano Bruno, Marsilio Ficino, Campanella y Giovanni Pico della Mirandola llegan a considerar a Hermes Trismegisto un profeta pagano sabio que predijo la llegada del cristianismo ${ }^{28}$ Creían en una prisca theologia, la doctrina de que existe una única y verdadera teología, que se entreteje a través de todas las religiones, que fue dada por Dios al hombre en la antigüedad, y que pasa a través de una serie de profetas, que incluían a Zoroastro y Platón. A fin de demostrar la veracidad de esta teología los cristianos se apropiaron de las enseñanzas herméticas para sus propios propios fines. De esta manera, Hermes Trismegisto (según los padres de la iglesia cristiana), resulta contemporáneo de Moisés o el tercero de una línea de hombres llamados Hermes, Enoc, Noé, y el rey-sacerdote egipcio que se sabe que nosotros

\footnotetext{
${ }^{28}$ La Oratio de hominis dignitate, de Pico della Mirandola, abre con una cita del erudito musulmán Abd-Allah ibn Qutaybah, quien declaró que no había nada más maravilloso en el mundo que el hombre, y sigue con la famosa cita de Hermes Trismegisto: "¡Qué gran milagro es el hombre, Asclepio".
} 
como Hermes Trismegisto o "tres veces grande" a causa de ser el más grande sacerdote, filósofo y el rey.

En la Biblia no se hace mención de Hermes; para el mundo cristiano, el hermetismo era considerado una religión egipcia. Sin embargo, a diferencia de Hermes, Egipto desempeñó un papel importante en el Antiguo Testamento. Debemos recordar el Egipto de la Biblia para entender el trasfondo del cual surge la imagen cristiana medieval de Hermes. En el Antiguo Testamento la imagen dominante de Egipto es la del Éxodo. Para el judaísmo, el motivo de la "liberación de Egipto" es una profesión de fe fundamental que en repetidas ocasiones pone a Dios, como libertador y en el centro de la certeza religiosa. El recuerdo de la redención y la liberación de la opresión se ha establecido firmemente en la vida judía en la fiesta de la Pascua. Desde esta perspectiva, Egipto e Israel se muestran totalmente incompatibles: el monoteísmo contra el politeísmo y la idolatría frente a la prohibición de imágenes (Ebeling 7).

Para los cristianos, en cambio, resulta más fácil formarse una imagen positiva de Egipto, pues el Nuevo Testamento menciona explícitamente a Egipto una sola vez y de manera positiva. Una vez más, Egipto es un lugar de refugio, esta vez de la persecución de Herodes de la Sagrada Familia: this connection between Jewish and Egyptian thought cannot be considered a simple, linear continuation of a common tradition; rather, drawing on this motif were many conceptions of an esoteric, that is, a hidden and superficially invisible philosophia 
perennis underlying Judeo-Christian and Egyptian-Hermetic wisdom. (Ebeling 38-39)

San Agustín reconoce que Hermes comprende y representa adecuadamente a Dios como creador, pero la idea de que los hombres están en igualdad de condición que el propio Dios, pensaba el obispo de Hipona, debía ser la obra de algún demonio maligno. San Agustín, sin embargo se convirtió sin proponérselo en defensor del hermetismo, gracias a una atribución errónea de autoría. Lactancio, escritor latino y apologista cristiano, citando partes del griego original del Asclepio o Esculapio, invocó a Hermes Trismegisto en defensa del dogma trinitario contra sus adversarios paganos. San Agustín encontró esas ideas profundamente inspiradoras, y así, el filósofo, teólogo y santo cristiano "could be called upon to either condemn Hermes as a pagan or to laud him as a harbinger of Christ" (Ebeling 42-43).

Existe la creencia de que el pensamiento hermético desapareció de Europa poco después de que el cristianismo se convirtiera en la religión dominante del imperio romano, y que no es hasta la época renacentista que resurge como materia filosófica. Sin embargo, el nombre de Hermes Trismegisto continuó siendo muy conocido en la Edad Media gracias a su conexión con la alquimia, la magia y la preparación de talismanes. No obstante, es a causa de la prohibición de estos textos de corte hermético, considerados diabólicos por el doctor de la Iglesia, Alberto Magno (12001280) y de la censura por parte del cristianismo, que el hermetismo es condenado a una existencia clandestina. 
Los tratados que hoy conocemos como Corpus hermético fueron agrupados en un solo tomo en la época bizantina, y considerados por muchos eruditos del Renacimiento como textos del propio Hermes Trismegisto; una copia de estos escritos llegó a manos de Lorenzo de Medici en el siglo XV y Marsilio Ficino, director de la Academia Florentina, fue encargado de traducir el Corpus hermético al latín. ${ }^{29}$ Su traducción salió impresa el año 1463, y fue reimpresa unas veintidós veces a lo largo de un siglo y medio (Greer, "Introduction" 1).

El aspecto filosófico del hermetismo se basa en la doctrina de las correspondencias. En la ascensión hermética, cada planeta corresponde a determinado poder del alma: Mercurio a la inteligencia, Venus al deseo, Marte a la ira, etc. Así, el ser humano es un microcosmos que contiene las mismas energías que el macrocosmos. Si imaginamos la Tierra en el centro del universo, el alma ha adquirido estas energías en su viaje descendente, (o interior) desde las regiones celestiales a través de las esferas planetarias y surge a la vida terrenal via el vientre materno. Durante la vida, el alma trabaja con estas potencialidades con la esperanza de refinarlas para que emerjan como virtudes. Si logra su objetivo, al abandonar su cuerpo en la muerte, se convierte en luz y está lista para ascender (al exterior) a su lugar de origen. Si por el contrario, las energías se han convertido en vicios, entonces el viaje ascendente se tornará difícil y el alma podría permanecer atrapada en la atmósfera de la tierra.

${ }^{29}$ Entre los textos filosóficos encontrados se destacan: el Asclepio, también llamado el Sermón Perfecto; los Extractos de Estobeo y el Corpus hermético (Mahé 288). 
Aunque muchos textos han sido falsamente atribuidos a Hermes Trismegisto, los herméticos comúnmente aceptan cuarenta y dos libros como componentes genuinos de la revelación hermética. La mayoría de estos son obras que se encuentran perdidas o que fueron destruidas por el fuego en Alejandría. Sin embargo, existen tres fuentes principales que contienen la esencia de las creencias herméticas:

- El Corpus hermético - la obra más conocida que contiene los textos griegos mencionados. Estos dieciséis libros se configuran como el diálogo entre Hermes y una serie de interlocutores. El primer libro es una conversación entre Poimandres (también conocido como Nous y Dios) y Hermes, supuestamente como resultado de un estado de meditación, y es la primera vez que Hermes entra en contacto con Dios. Poimandres enseña los secretos de universo a Hermes, y los libros posteriores generalmente consisten en Hermes pasar estas revelaciones a otras personas (como Esculapio y su hijo Tat).

- La Tabla de Esmeralda de Hermes Trismegisto - una obra corta que contiene la conocida máxima oculta: "Como arriba, es abajo". La tabla también hace referencia a las tres partes de la sabiduría de todo el universo. De acuerdo con la Tabla, la sabiduría del universo se puede subdividir en tres esferas de la siguiente manera :

Alquimia - La operación del sol. Esta disciplina no es simplemente cambiar plomo en oro físico. Se trata de una investigación sobre la constitución espiritual, o la vida de la 
materia y la existencia material a través una aplicación de los misterios del nacimiento, muerte y resurrección. Las diversas etapas de destilación y fermentación química son aspectos de estos misterios, que se aplican para acelerar Naturaleza a fin de lograr un cuerpo natural perfecto.

Astrología - La operación de la Luna. Hermes afirma que Zoroastro descubrió esta parte de la sabiduría. En el pensamiento hermético, es probable que los movimientos de los planetas tengan un significado más allá de las leyes de la física, y de hecho, la astrología tiene influencias sobre la Tierra, pero no dicta nuestras acciones, y la sabiduría se adquiere cuando se sabe lo que estas implican y cómo utilizarlas. Teurgia - El funcionamiento de las estrellas. Según la Apología de Giovanni Pico della Mirandola, hay dos diferentes tipos de magia, que son polos opuestos el uno del otro. El primero es la magia negra que depende de alianzas con los malos espíritus (es decir, demonios). La segunda es la Teurgia, la magia divina que depende de alianzas con los espíritus divinos (es decir, los ángeles, arcángeles, dioses ). Por otra parte, la alquimia es vista como la "Clave" para la teurgia, el objetivo último es estar unirse a la Conciencia Divina.

- El kybalión - A pesar de su origen moderno, el texto contiene exposiciones lúcidas de muchos de los principios herméticos, lo que le 
valió un lugar de prominencia entre hermética moderna. Sale a la luz en 1908 y pretende ser la esencia de las enseñanzas de Hermes Trismegisto. Fue publicado anónimamente por un grupo que se llamó "Los tres iniciados", y presenta siete principios universales del hermetismo. ${ }^{30}$

Este último está escrito a manera de comentario de unos supuestos axiomas herméticos. El contenido se centra en un conjunto de siete principios derivados de la filosofía hermética (Greer 262-263). ${ }^{31}$ Hay quienes aseguran que los aforismos del El kybalión son muy probable un fraude, pues su estilo y modo de pensamiento son más evocadores de la América del siglo XX que del antiguo Egipto o Grecia. Sin embargo, sería un error concluir que este trabajo es infiel a la tradición hermética. Una tradición espiritual se basa, sin duda, en las verdades eternas e inmutables, pero la aplicación que se da a

30 Los "tres iniciados" que supuestamente escribieron el Kybalión decidieron permanecer en el anonimato, y esto ha generado muchas especulaciones sobre quién escribió realmente el libro. Varias escuelas de pensamiento se atribuyen su autoría. La teoría más popular es que Paul Foster Case, Michael Whitty y William Walker Atkinson (también conocido como Yogi Ramacharaka, Swami Panchedasi, Magus Incognito, Theodore Sheldon y probablemente muchos otros pseudónimos conocidos y desconocidos) eran los "tres iniciados" que escribieron el libro.

${ }^{31}$ El Kybalión se asegura que:

No hay porción de las enseñanzas ocultas poseídas por el mundo que haya sido tan cuidadosamente guardada como los fragmentos de las enseñanzas herméticas que han llegado hasta nosotros a lo largo de las decenas de centurias que han trascurrido desde la vida de su gran fundador, Hermes Trismegistus, el "escriba de los dioses", que residió en el antiguo Egipto en los días en que la raza presente de los hombres estaba en su infancia. Contemporáneo de Abraham, y, si las leyendas son verdaderas, un instructor de ese venerable sabio, Hermes fue, y es, el gran sol central del ocultismo, cuyos rayos han servido para iluminar las innumerables enseñanzas que han sido promulgadas desde su tiempo. Todas las enseñanzas fundamentales y básicas contenidas en las enseñanzas esotéricas de toda raza pueden ser atribuidas a Hermes. (1) 
estas verdades puede variar de una época a otra, de acuerdo con la necesidad del momento. En este sentido, El kybalión puede reclamar una genuina herencia hermética.

El kybalión está organizado de acuerdo a siete principios básicos, según los cuales se basa la filosofía del ocultismo. El primero es el "mentalismo", este precepto establece que todo es mente. Explica también que todo el mundo o universo fenomenal es simplemente una creación mental. El hermético está capacitado para aplicar inteligentemente las grandes leyes mentales en vez de usarlas de una manera fortuita. su uniformidad, demuestra la unidad de el espíritu de informar, o la mente, que subsiste eternamente y con independencia de cualquier manifestación.

El segundo principio es la "correspondencia", que establece la máxima "Como es arriba, es abajo; como es abajo, es arriba". Se afirma que este principio se manifiesta en los tres grandes planos: el físico, el mental y el espiritual. Igual que los conocimientos matemáticos capacitan al hombre para medir soles distantes y sus movimientos, mientras está sentado en su observatorio, así un conocimiento del principio de correspondencia capacita al hombre para razonar inteligentemente desde lo conocido hasta lo desconocido. La ley de la correspondencia establece que el macrocosmos es como el microcosmos, lo universal como lo individual, el mundo como el hombre, y el hombre como Dios. Un hombre en la tierra, es un Dios mortal, y el Dios celestial es hombre inmortal. 
El próximo principio es el de "vibración", y dice que nada está inmóvil, todo se mueve, todo vibra. Un entendimiento de este principio, con las fórmulas apropiadas, capacita a los estudiantes herméticos a controlar sus propias vibraciones mentales, así como las de otros. Los maestros también aplican este principio a la conquista de los fenómenos naturales, en modos diversos. Impregna todos los planos de la espiritualidad y de la física, y es de acuerdo a su densidad espiritual que se determina el plano del individuo.

Luego tenemos el principio de la "polaridad", que establece que todo es doble, todo tiene dos polos, todo tiene su par de opuestos: los semejantes y los antagónicos son lo mismo; los opuestos son idénticos en naturaleza, pero diferentes en grado; los extremos se tocan; todas las verdades son medias verdades, todas las paradojas pueden reconciliarse.

El principio del "ritmo" asegura que todo fluye y refluye; todo tiene sus períodos de avance y retroceso, todo asciende y desciende; todo se mueve como un péndulo; la medida de su movimiento hacia la derecha, es la misma que la de su movimiento hacia la izquierda; el ritmo es la compensación. El movimiento del universo es la eternidad. El universo nunca dejará de moverse. Todas las cosas son ordenadas en el tiempo por la acción del sol y de las estrellas, de acuerdo con una ley divina. Los períodos terrestres se distinguen por el estado de la atmósfera, por las alternativas de calor y frío; los períodos celestes por las revoluciones de las constelaciones, que regresan a intervalos fijos de tiempo a los mismos lugares en el cielo. El universo es el curso y el movimiento que mantiene la vida. 
La "causa y el efecto" indica que toda causa tiene su efecto y todo efecto tiene su causa. Todo sucede de acuerdo a esa ley, pues la suerte o azar no es más que el nombre que se le da a lo no conocido, y aunque hay muchos planos de causalidad, nada escapa a la ley de causa y efecto. La inexorable ley de causa y efecto se manifiesta en los asuntos morales, en virtud de que la naturaleza y las condiciones en el futuro del hombre son el resultado de las tendencias voluntariamente animadas por este en el pasado y en el presente.

Por último, el principio de "generación" o "género" trabaja siempre en la función de la creación. Toda cosa y toda persona contiene los dos elementos o principios dentro de sí. Todo macho tiene también el elemento hembra y toda hembra contiene también el principio macho. La relación de los sexos simboliza los más altos misterios divinos, y ordena su ejercicio como una obligación, cuyo cumplimiento, en al menos algunos de sus encarnaciones, es esencial para el perfeccionamiento completo y el inicio de la persona. Esta ley de generación se encuentra en la Naturaleza, en el intelecto y en todo el universo.

El hermético haciendo uso de estos conocimientos debe, mediante el principio del mentalismo, seleccionar la vibración deseada entre los dos polos (positivo-masculino/negativo-femenino) y polarizarse (mediante el proceso de alquimia mental) en el punto deseado. Luego debe neutralizar la oscilación rítmica entre los dos polos que lo conduciría hacia el otro polo. En el proceso de oscilación rítmica hay siempre una acción y una reacción, y este principio 
se manifiesta en la creación y destrucción de todas las cosas y estados mentales.

Como se puede apreciar, existe una importante conexión entre el pensamiento hegeliano y los antiguos principios herméticos. El hermetismo trasciende tanto el monoteísmo y el politeísmo, así como el deísmo y el panteísmo. Su filosofía enseña que hay un Dios trascendente, o Absoluto, en el que nosotros y el universo entero participamos. También se adhiere a la idea de que otros seres, como los dioses, ángeles y elementales, existen en el universo. En su libro Hegel and the Hermetic Tradition, Glenn Alexander Magee afirma que el filósofo alemán era en realidad un seguidor de la tradición hermética. La vida y las obras de Hegel ofrecen una amplia evidencia para esta tesis. El propio Hegel admite en su Filosofía del espíritu que "el mundo suprasensible es, de este modo, un tranquilo reino de leyes, ciertamente más allá del mundo percibido" (58). De hecho, Hegel sostiene en más de una ocasión que el término "especulación" significa lo mismo que "mística", cree en el "Espíritu de la Tierra", y mantiene correspondencia con sus colegas sobre la naturaleza de la magia. Además, según afirma Hegel la magia se identifica de manera informal, con sociedades "herméticas" como la masonería y los rosacruces. ${ }^{32}$ Hegel parece estar realmente interesado en el

\footnotetext{
${ }^{32}$ La biblioteca de Hegel contaba con obras de: Heinrich Cornelius Agripa (14861535 ) escritor, filósofo, alquimista, cabalista y médico, quien en su obra principal, De occulta philosophia libri tres (1531) recogió todo el conocimiento medieval sobre magia, astrología, alquimia, medicina y filosofía natural y lo respaldó teóricamente; Jakob Böhme (1575-1624), filósofo místico alemán de tendencia panteísta. Sus obras influyeron en la filosofía idealista alemana; Giordano Bruno (1548-1600), astrónomo, filósofo, religioso y poeta italiano, que postuló la pluralidad de los mundos y sistemas solares, el heliocentrismo, la infinitud del espacio y el universo, y
} 
hermetismo, y si en verdad queremos entenderlo, debemos considerarlo un pensador hermético, pues "Hegel is not a philosopher. He is no lover or seeker of wisdom —he believes he has found it already" (Magee 1). Si Hegel es hermético o no dependerá de cómo se defina el hermetismo, el cual en sí es difícil de explicar, pues contiene elementos pertenecientes al llamado "ocultismo" o "esoterismo". De hecho, el hermetismo podría verse como un punto medio entre el panteísmo y el judeo-cristianismo en lo que respecta a la concepción de Dios. En el judeo-cristianismo, Dios se encuentra distante de la creación, es autosuficiente, y crea el mundo por pura abundancia y caridad, pues no tiene necesidad de este. Por otro lado, en el panteísmo todo se convierte en Dios, hasta el lodo, y lo sublime carece de divinidad.

La explicación de la necesidad de Dios para crear el universo supera algunos de los aspectos ilógicos de la historia bíblica de la creación. La tradición judeo-cristiana no provee ninguna buena razón por la que Dios haya querido crear el universo o la humanidad. Esta es una de las razones principales por las que la hermética atrae la atención de los pensadores

el movimiento de los átomos, por lo que fue juzgado y condenado a la muerte en la hoguera por la Inquisición. También se encuentra la obra de Theophrastus Phillippus Aureolus Bombastus von Hohenheim, conocido como Paracelso o Teofrasto Paracelso (1493-1541), médico y alquimista suizo nacido en 1493 que estableció el rol de la química en la medicina, y publicó el gran libro de la cirugía en 1536. También encontramos en la biblioteca hegeliana obras de Robert Fludd (15741637), quien fue un eminente médico, astrólogo y místico inglés, considerado uno de los grandes humanistas del Renacimiento. Fludd era ante todo un espiritualista que establecía una distinción entre la parte física mortal y la parte anímica inmortal del hombre. Y no podemos dejar de mencionar las obras de Christian Knorr von Rosenroth (1631-1689) hebraísta nacido en Alt-Raudten, hoy Stara Rudna en Silesia. Rosenroth tradujo al inglés la Kabbalah Denudata o "Kabbalah revelada", además de Platón, Galileo, Descartes y Newton. Para sus escritos de corte hermético, Hegel se basó en la obra de Giovanni Pico della Mirandola (Magee 123). 
renacentistas. La gran ventaja de la concepción hermética es que nos dice la razón por la que fue creado el cosmos y la une a la necesidad humana de conocer a Dios (Magee 56). Magee establece una serie de paralelismos entre el filósofo alemán y la tradición hermética, que nos servirán para ilustrar el punto de conexión entre nuestros autores y esta filosofía esotérica.

Magee se embarca en un ambicioso proyecto para demostrar que hay correspondencias sorprendentes entre la filosofía hegeliana y la filosofía hermética, y que estas correspondencias no son accidentales. Hegel se interesa activamente en el hermetismo, y se asocia con movimientos y pensadores herméticos a lo largo de su vida. Magee insiste en que veamos a Hegel no solo como un pensador hermético a la manera del idealismo alemán, sino que, como ya se ha postulado, si realmente queremos entenderlo, debemos considerarlo un pensador hermético (2).

La actitud de Hegel hacia la tradición hermética es más bien cautelosa, no obstante, encuentra en esta una manifestación de la sabiduría inconsciente de la filosofía perenne, que lucha por trascender su forma puramente sensual (Magee 103). Hegel se interesa por muchos temas esotéricos como el mesmerismo, la radiestesia fenomenal psíquica, la precognición y la hechicería, y estructuró su filosofía de una manera idéntica a la utilizada por la hermética mediante "correspondencias" o relaciones de unas cosas con otras. En el prólogo a la Fenomenología del espíritu, Hegel declara que su meta es lograr que la filosofía "se aproxime a la forma de la ciencia" hasta el punto en que "pueda dejar de llamarse amor por el saber 
para llegar a ser saber real: he ahí lo que yo me propongo" (5). Al finalizar esta obra, Hegel afirma haber llegado al conocimiento absoluto, que identifica con la sabiduría. ${ }^{33}$

De acuerdo con el hermetismo, Dios necesita crear para poder existir, y es precisamente esta una de las ideas principales de la filosofía hegeliana. Más aún, en el hermetismo, el ser humano desempeña un papel crucial en el reconocimiento que Dios hace de sí mismo. El ser humano puede llegar a conocer a Dios, y es mediante este conocimiento que Dios se completa. Esta doctrina "circular" entre Dios y la creación, y la necesidad que Dios tiene de ser completado es algo sumamente original. Nunca antes se había propuesto este pensamiento filosófico, pero es el punto más importante del hermetismo, y curiosamente, también de la filosofía de Hegel (Magee 9-10).

Tanto el hermetismo como la filosofía hegeliana se ocupan del proceso de iniciación mediante el cual la parte intuitiva del intelecto se entrena para descubrir la razón inherente en el mundo. Para verdaderamente adquirir conocimiento propio, debe saberse conversar con Dios y toda su creación. Sin embargo, sería un error considerar la iniciación hermética como un proceso enteramente intelectual. No solo se debe conocer la doctrina, sino también tener una verdadera experiencia de vida con la fuente de la doctrina. Solo así la verdadera doctrina tendrá sentido; solo así la vida del iniciado podrá cambiar y, como veremos, Hegel conserva los llamados

\footnotetext{
${ }^{33}$ El hecho de que Hegel afirme haber alcanzado la sabiduría es completamente contrario a la concepción de la filosofía griega como amor a la sabiduría, es decir, la búsqueda constante de esta.
} 
"momentos intelectuales y emocionales" de esta concepción hermética de iniciación (Magee 10-11).

Precisamente, otra semejanza entre la doctrina hermética y el hegelianismo es la concepción de lo divino como un conjunto de "instantes". Los herméticos no se contentan con la idea de un Dios desconocido, sino que buscan penetrar los misterios divinos. Sostienen que es posible llegar a conocer a Dios, conociendo los diversos aspectos de lo divino. Para los herméticos, el cosmos no es meramente un caos, sino que todo en el universo se encuentra internamente relacionado, conectado con todo lo que existe. A pesar de que el cosmos se encuentra organizado de manera jerárquica, existen fuerzas que se encargan de unirlo todo. Se trata de poderes divinos o "energías" que lo atraviesan todo. El significado más importante de esta doctrina es la idea de que el ser humano es el microcosmos, dentro del cual se refleja el macrocosmos. El conocimiento propio, por lo tanto, lleva al conocimiento del todo.

Otro paralelo entre Hegel y el hermetismo reside en la doctrina de las relaciones internas. Para los herméticos, el cosmos no es una creación inconexa, o en términos hegelianos, un conjunto de partes relacionadas externamente, sino que todo en el cosmos se encuentra internamente relacionado. Sin embargo, aunque el cosmos esté arreglado de manera jerárquica, existen fuerzas que lo atraviesan y unifican en todos sus niveles. Existen poderes divinos que son interpretados como "energía" o "luz" que lo bañan todo. La implicación más importante de esta doctrina es la idea de que 
el ser humano es el microcosmos en el cual todo el macrocosmos se ve reflejado. De esta manera, el conocimiento propio lleva inevitablemente al conocimiento del todo (Magee 13).

En el Corpus hermético encontramos una conexión entre la doctrina hermética y la filosofía hegeliana. El texto, en vez de concebir palabras que con un poder oculto literal, las palabras mismas se convierten en una fuente de poder. Este conocimiento espiritual no es meramente intelectual, se espera que verdaderamente cambie la vida del iniciado. De manera similar, para Hegel, la filosofía tiene que ver con la vida misma. El hermético no tiene que escapar del mundo con el fin de salvarse a sí mismo, sino que quiere adquirir conocimientos sobre el mundo con el fin de ampliar su conocimiento propio, y utilizar este conocimiento para penetrar en el ser de Dios (Vondung 132). Es decir, el ser humano que logra conocerse a sí mismo, logra también un estado de confianza propia y de realización; ya no es un ser humano común y corriente.

En su Filosofía de la Naturaleza, Hegel incorpora las creencias de las ciencias naturales de su época. Al mostrarle a la humanidad un Dios que se expresa en parte en la naturaleza, Hegel espera volver a conectar la ciencia con la experiencia de lo divino, y específicamente con la presencia concreta de lo divino. (Magee 97). La ciencia occidental moderna ha asumido desde el principio que la mente no desempeña ningún papel en la naturaleza, y esta creencia efectivamente filtra las pruebas empíricas que demuestran lo contrario. El materialismo esboza una teoría de un universo sin sentido, y los 
físicos concluyen que no hay pruebas de la existencia de una mente "no" física y sobrenatural. Puesto que la ciencia carece de una teoría coherente de la mente o de la conciencia, la evidencia de su papel activo en la naturaleza es generalmente descartado o simplemente pasa inadvertido. La cosmología moderna se basa en la suposición de que la mente y la vida son simplemente producto de la materia y la energía, así que es inevitable que cualquier teoría del cosmos considerará el surgimiento de la conciencia como algo secundario o accidental, separado de los procesos físicos. Este no es en absoluto el único supuesto metafísico que subyace en esta ciencia; otra característica fundamental de la cosmología se conoce como el principio de contención, que dice que el universo físico contiene todo lo que es físico y nada más (Wallace 1).

En el hermetismo se requiere un estado inicial de purificación para erradicar todas las falsas creencias intelectuales. En el sistema hegeliano también se propone un sistema de limpieza similar, en el que el iniciado se prepara para recibir la doctrina del conocimiento absoluto. En el principio del mentalismo, el individuo comprende las leyes de la Mente Universal, y así puede aplicarlas para su bienestar y progreso. La filosofía hegeliana propone que el universo es un todo compuesto de relaciones internas atravesado por energías cósmicas.

La conexión entre la doctrina hermética y los postulados de la filosofía hegeliana puede resumirse de la siguiente manera: Dios siente la necesidad de crear para poder ser Dios. Hegel sostiene en su Filosofía de la Naturaleza 
que Dios es "creación", la Naturaleza es tan solo uno de los "instantes" de Dios. Es decir, una de las maneras en que Dios se manifiesta. Existen muchos planos de existencia desconocidos para nosotros, pero aplicando este principio podemos expandir nuestro entendimiento, ya que todo es más que un reflejo de algo que ya conocemos. La correspondencia actúa haciendo que lo similar se agrupe con lo similar por una sintonización de la frecuencia vibratoria y explica la constante relación entre los acontecimientos internos y externos.

Dice el hermetismo que Dios se siente "completo" o realizado por medio de la contemplación que hace el ser humano de este. Hegel opina que Dios se hace "completo" o se actualiza a través de la actividad intelectual de la humanidad. La filosofía es la etapa final de esta realización del Espíritu Absoluto. Hegel ve este proceso como una concepción circular de Dios y el cosmos; Dios regresa a sí mismo y se convierte en Dios gracias al ser humano. Aquí reconocemos el principio hermético del ritmo. Por cada acción hay una reacción; todo en el universo se encuentra en constante transformación y movimiento, nada está inmóvil ni estancado. A través de la transmutación mental, el hermetismo afirma, que es posible elevarse sobre la oscilación rítmica y polarizarse en el polo deseado, pero esto solo es posible a través de la elevación del nivel de conciencia y el ejercicio de la voluntad. En el caso de estar inmerso en un ritmo negativo, la tendencia natural es que ese ritmo se mantenga, y solo podrá cambiarse con una toma de conciencia 
y ejerciendo la voluntad para crear deliberadamente un ritmo diferente y opuesto al anterior.

Para el hermético, la experiencia del conocimiento espiritual consiste en captar la totalidad de la realidad mediante la palabra. Hegel, a su vez, desea capturar la totalidad de la palabra mediante un lenguaje circular. El principio de la polaridad explica las antiguas paradojas de la humanidad; tesis y antítesis son iguales en naturaleza, tan solo están en diferencia de grados. El principio de polaridad funciona a lo largo de una escala vibratoria de grados que va de lo positivo a lo negativo, siendo lo positivo de naturaleza superior a lo negativo: en cada cosa hay dos polos, en la temperatura está el frío y el calor, y aunque son opuestos son una misma cosa. El espíritu y la materia son la misma cosa pero se manifiestan mediante la vibración de los opuestos.

En el hermetismo, el ser humano puede perfeccionarse por medio de la "gnosis" o conocimiento; adquiere poder gracias a que posee un lenguaje completo, y Hegel cree que nos elevamos más allá de la naturaleza y nos convertimos en dueños de nuestro propio destino mediante el conocimiento provisto por su sistema. El principio de la vibración actúa en los planos de energía, fuerza, mente y espíritu. Todo se mantiene en estado vibratorio.

El ser humano puede conocer los aspectos o "momentos" de Dios, según el hermetismo. La lógica de Hegel es un intento por conocer los aspectos o "instantes" de Dios mediante un sistema de ideas. En el principio de causa y efecto todo ocurre de acuerdo a la ley universal. Nada sucede sin 
razón, cada instante tiene una razón (causa) y una culminación (efecto). En el hermetismo, en cambio, se asume una posición intermedia. Se afirma tanto la trascendencia de Dios como su relación con el mundo. Dios es metafísicamente distinto, sin embargo necesita al mundo para completarse. No es arbitrario, sino necesario y racional. La filosofía hermética nos dice el por qué Dios existe (Magee 8).

Según Abrams, la Fenomenología es uno de los más originales e influyentes libros jamás escritos, pero un error común es intentar leerlo como una obra de "systematic philosophy, against Hegel's explicit warning that it is not philosophy—or rather that it is, yet it is not philosophy" (Natural Supernaturalism 227). De hecho, el libro está deliberadamente compuesto a la manera de la narrativa literaria, y no en un modo de exposición filosófica o de demostración, pues Hegel encarna "this spiritual and intellectual history of mankind in the prevailing metaphorical vehicle of the Bildungsweg, the educational journey (Abrams 228). ${ }^{34}$ Su afirmación es plenamente coherente con las ambiciones de la tradición hermética (Magee 1).

${ }^{34}$ Bildungsweg: curso de formación o trayectoria de aprendizaje. 


\section{CAPÍTULO III}

“Celín”: Vibración y ritmo universal

We are a way for the cosmos to know itself.

Carl Sagan

If we discover a complete theory, it should in time be understandable by everyone, not just by a few scientists. Then we shall all, philosophers, scientists and just ordinary people, be able to take part in the discussion of the question of why it is that we and the universe exist. If we find the answer to that, it would be the ultimate triumph of human reason ---for then we should know the mind of God.

Steven Hawking

En el prólogo a la colección La sombra, donde aparece el cuento el "Celín”, Galdós confiesa que a veces: "Se empeña uno... por cansancio o por capricho, en apartar los ojos de las cosas visibles y reales" (67). No se explica, "ni hace falta" explicar su incursión "en un terreno que no le pertenece", y aduce que las historias allí contenidas "son solo "divertimientos, juguetes, ensayos de aficionado" (67-68). No obstante, esta insistencia en la disculpa parece sospechosa si consideramos que, como apunta Joseph Schraibman, resulta paradójico que un artista dotado con la imaginación fantástica de Galdós se presente como un excelente ejemplo de "realismo" por los críticos cuya visión realista incluye la veneración por lo fotográfico, es decir, restricciones muy precisas impuestas a lo raro, lo extraño, a la imagen artificial (184-85). De hecho, el interés de Galdós en lo sobrenatural es evidente en la totalidad de su producción novelística. Uno esperaría que 
cualquier autor que propone retratar de manera realista la sociedad en todos sus aspectos, como hace Galdós, refleje también las ideas y actitudes de dicha sociedad ante lo sobrenatural (136). Por tanto, no debe sorprender al lector que la obra galdosiana esté llena de incursiones al mundo de lo fantástico o sobrenatural, incluso "podemos ver en el rechazo de una estética realista convencional" que esta "le había quedado siempre un poco estrecha" (Smith 231). Galdós va más allá del mundo de la descripción "de la realidad material para explorar zonas de significación espiritual y de hondura multifaria y de diversidad de perspectivas" (Correa 8).

El cuento "Celín" se compone de siete capítulos un tanto extensos para lo esperado de este género literario, cada uno con un título que funciona a manera de resumen de lo acaecido y "se basa en una estructura temporal deliberadamente confusa" (Ezama Gil, "El manuscrito" 91). ${ }^{35}$ La acción comienza cuando Diana, a raíz de la súbita muerte de su novio, don Galaor de Polvoranca, decide suicidarse lanzándose al río de Turris, ciudad donde se desarrolla la historia. Tan solo existe un problema, en Turris todo se encuentra en constante movimiento, desde las edificaciones, hasta el caudaloso río Alcana. La chica, hallándose perdida, se encuentra con un enigmático niño que se ofrece a guiarla por el extraño lugar. Las variaciones espaciales provocadas por el misterioso movimiento de la ciudad y del río,

${ }^{35}$ Ángeles Ezama Gil ha realizado un exhaustivo estudio del manuscrito n. ${ }^{\circ} 7714$ de la Biblioteca Nacional de Madrid, correspondiente a "Celín". Ezama Gil compara el estilo de las diversas versiones del manuscrito con la primera edición de 1889. 
los llevan en un periplo lleno de portentosos acontecimientos que van disuadiendo a Diana de su objetivo. El chico (llamado Celín), ser misterioso por demás, va creciendo a pasos agigantados hasta convertirse en un hermoso mancebo que le va mostrando las maravillas de la vida por medio de la Naturaleza que los acoge y se les regala. Celín invita a Diana a disfrutar de los placeres que él mismo le va descubriendo, hasta terminar el recorrido en la alcoba de Diana, despertando esta de un profundo sueño. Celín, convertido en un "pichón" que le confiesa ser el Espíritu Santo, desaparece luego de ofrecerle su mensaje de júbilo y renovación.

El narrador galdosiano señala que la historia se basa en los supuestos acontecimientos reportados por Gaspar Díez de Turris, cronista de las ilustres casas de Pioz y Polvoranca, y de quien se rumora parece tener afición por "un medicamento que no se compra en la botica" (Pérez Galdós, "Celín" 294). Este pintoresco personaje, caracterizado por Galdós como poco confiable, nos hace recordar al Cide Hamete cervantino (Schulman, "Brief Narratives" 72). No obstante, es sobre este cronista alcoholizado y distraído que descansa la historia de Diana, "hija única del marqués de Pioz, cuyos títulos, honores y preeminencias rebasaban el papel de la Crónica, si se pusiesen todos en ellas” (Pérez Galdós, “Celín” 295).

Sebastián de la Nuez ha señalado que al estar la estructura de la obra fundamentada "desde la perspectiva del autor omnisciente" ceñido al relato de los acontecimientos de este supuesto cronista, Galdós "queda a salvo de todas las fantasías o sueños que pudieran aparecer en su narración”, 
añadiéndole "el tono acusadamente irónico, que sí es propiamente galdosiano" (189). Se trata, desde luego, de un ardid literario del que se vale Galdós para justificar los confusos acontecimientos que se dispone a contar. Para quienes sitúan a "Celín" dentro del género alegórico-fantástico, el argumento de Sebastián de la Nuez resulta indispensable, puesto que descubre tres niveles simbólico-alegóricos dentro de la estructura general. El primero es intencional y se desprende del pie forzado de los meses. El segundo nivel resulta cronológicamente impreciso, en el que personas, objetos y costumbres anacrónicas coexisten. El tercer nivel se refleja en el viaje "supuestamente real" de los jóvenes, que concluye con el "despertar de un sueño" que representa "la regeneración de la naturaleza gracias a la evolución espiritual que experimentan Diana y Celín" (188).

Por su parte, Alan E. Smith difiere de esta interpretación, ya que le parece que existe una discrepancia entre "una representación simbólica", la cual "es mucho más polisémica" y "una alegoría", que nos "remite a un metasentido puntual” (225). Smith considera que aun como representación simbólica del mes de noviembre no logra su cometido, ya que escasamente se menciona el mes, sino que se dice de la gente acudía a los teatros a ver el Don Juan Tenorio, y que había muchos puestos de castañas y rondas de penitentes rezando el Santo Rosario, por ser Noche de Difuntos. No obstante, "Celín" encaja dentro del ámbito de lo sobrenatural. Diana despierta de su sueño, el cual en definitiva presenta elementos maravillosos que rompen con las leyes físicas, para experimentar otro suceso maravilloso. El 
narrador interviene para advertir al lector que: "parece que aquí debía terminar lo maravilloso que en esta Crónica tanto abunda; pero no es asi" (Pérez Galdós, "Celín" 343). La paloma resulta ser un ave parlante que le resume a Diana el significado de su viaje y le aconseja vivir disfrutando cada etapa de su existencia. De esta manera, concluye Smith, "Celín" puede catalogarse "dentro de 'lo maravilloso' y preponderantemente, cualitativamente, libre de la forma alegórica" (225).

Ezama Gil apunta en cambio, que "Celín" resulta "un cuento maravilloso sólo en parte, fundamentalmente en lo que concierne a los personajes y sus aventuras" (“El manuscrito" 97), puesto que:

Con la doble distancia espacial y temporal, se consigue crear ese efecto de irrealidad necesario para ambientar un relato construido de acuerdo con las convenciones del cuento maravilloso, pero en el cual tales convenciones no son sino un medio fácil de abordar un escabroso tema, el del despertar femenino a la vida mediante el descubrimiento del sexo. (Ezama Gil, "La invención del espacio" 1)

La transformación de niño a hombre que sufre Celín, esa "evolución física del muchacho" es el agente catalítico del germinar erótico de Diana (Ezama Gil, "El manuscrito" 94). La aproximación física y emocional que se produce entre los protagonistas conforme el chico va convirtiéndose en un apuesto mancebo hacen que la joven comience a sentir una perturbadora atracción por este. 
De todo lo anterior se desprende la dificultad de catalogar este inusual relato galdosiano, que por su extensión se asemeja más a la novela corta que al cuento, y "está cargado de humor a través de la cervantina figura de ese cronista, cuya afición a la bebida es más que un rumor y que en consecuencia relativiza desde el inicio toda la narración" (Gutiérrez-Díaz Bernardo 31-32). Tomando en cuenta lo inusitado de la trama de este cuento, propongo una lectura a la luz de la tradición hermética, ya que toda una serie de sucesos acaecidos en el enigmático espacio-tiempo de la ciudad de Turris, pueden interpretarse mediante los preceptos de esta antigua filosofía. Acaso el acontecimiento más sorprendente narrado en el cuento sea el movimiento de la ciudad de Turris, puesto que en este extraño lugar todo se mueve y cambia de lugar cada veinticuatro horas. El narrador de la historia abre un paréntesis para aclarar la peculiar geografía de la mencionada ciudad advirtiendo que:

Hay que hacer... una aclaración de carácter geográfico, que sorprenderá mucho al lector... Pues ello es un fenómeno físico, peculiar de la ciudad de Turris, y que en ninguna otra parte del globo se ha manifestado nunca... La ciudad de Turris se mueve. No se trata de terremotos, no: es que la ciudad anda, por declinación misteriosa del suelo, y sus extensos barrios cambian de sitio sin que los edificios sientan la más ligera oscilación, ni puedan los turriotas apreciar el movimiento misterioso que de una parte a otra les lleva... A veces la calle 
que anocheció curva, amanece recta, sin que se pueda fijar el momento del cambio. Los barrios del Norte se trasladan inopinadamente al Sur. Los turriotas, al levantarse todas las mañanas, tienen que enterarse de las variaciones topográficas ocurridas durante la noche, pues a lo mejor aparece el Tribunal de Cuentas al lado de la Plaza de Toros, y el Congreso frente al Depósito de caballos padres. (307-08)

Este inexplicable cambio topográfico suele ocurrir en la noche, por lo que el municipio emplea pregoneros que van voceando en las mañanas "la nueva topografía, y se ponen carteles diciendo, 'La cárcel se ha corrido al oeste'. (Pérez Galdós, "Celín" 308). En la ciudad de Turris el centro se mueve poco en contraste con las extremidades radiales de la ciudad, que se desplazan de manera tan rápida e inapreciable como la rotación del planeta. Se nos informa que "las arterias radiales de la ciudad y sus extremidades son las que se revuelven, se cruzan y se enroscan como los rejos del pulpo" mientras este aparente caos turriota parece seguir un orden que no se manifiesta abiertamente ante los ojos de sus ciudadanos, quienes, a pesar de no comprender el origen de estos cambios, se han adaptado a las constantes variaciones geográficas de su tierra (308).

Si examinamos este fenómeno bajo el lente de la tradición hermética, encontramos una posible explicación a esta anómala característica turriota. La docrina esotérica del hermetismo plantea que todo cuanto existe en el universo se encuentra en una constante "vibración", ya que "nada está en 
reposo, todo se mueve, vibra y gira" (El kybalión 12). De acuerdo con la explicación que nos ofrece la filosofía hermética, todas las partículas de materia existente están en movimiento, desde la más diminuta hasta los más grandes cuerpos celestes. Ya la ciencia moderna ha descubriendo niveles infinitesimales de vibración que explican por qué los objetos a nuestro alrededor parecen sólidos cuando realmente son un conjunto de átomos que vibran y se mueven tan rápidamente que a simple vista dan la impresión de inmovilidad. Los planetas giran alrededor de soles, y muchos de ellos giran sobre sus ejes. Se sabe además, que las estrellas se mueven alrededor de puntos medulares, y que estos se mueven alrededor de otros aún mayores, y así sucesivamente. Las moléculas de que están compuestas los distintos tipos de materia están en un estado de vibración y movimiento constante unas alrededor de las otras. A su vez, las moléculas están compuestas de átomos, los que, igualmente, están en un estado de movimiento y vibración constante. Los átomos están compuestos de corpúsculos, llamados electrones o iones, que también están en un estado de acelerado movimiento, girando uno alrededor del otro en un modo de vibración muy rápido (13-15). De igual modo, en Turris no solo se mueven los cuerpos animados, sino también los inanimados, puesto que estas fuerzas hacen que todas las cosas aumenten, fructifiquen, maduren, se descompongan, se disuelvan, se muelan y sufran "todos aquellos cambios a los que los cuerpos inanimados son susceptibles" (Los libros de Hermes Trismegisto 222-23). De ahí que, "todo lo que se mueve está vivo, y la vida universal es una 
transformación necesaria", por lo que "no puede haber producción sin movimiento" (126).

El fenómeno de la vibración también puede verse en la perturbación y el desconsuelo que sufre Diana de Pioz debido a la prematura muerte de su prometido. Ingenuamente supone que suicidándose tomará control de su existencia: "ya vería el mundo quién era ella y qué geniecillo tenía para aguantar los bromazos de la miseria humana" (Pérez Galdós, "Celín” 302). El hermetismo explica que los pensamientos también se componen de partículas que vibran en una frecuencia tan rápida que resultan invisibles a nuestros ojos. Sin embargo, los estados emocionales depresivos hacen que esa vibración oscile a un ritmo mucho más lento y denso. Es ese el punto en el que se encuentra Diana. Por su mente corre la idea de matarse, creyendo así que el dolor y la confusión emocional que la anegan dejarán de atormentarla. La chica concluye que no vale la pena sobrevivir a su prometido, ya que el dolor "que le atenazaba las entrañas" era peor que la muerte misma (302). Así pues, luego de que todos en el palacio se retiraran a sus aposentos, sale la inconsolable chica a las enmarañadas calles de Turris.

El inesperado fallecimiento del capitán don Galaor, quien muere de tifus el último día de octubre, es el suceso catalizador de toda la serie de insólitas experiencias que Diana enfrentará a lo largo de la obra. Su entierro se lleva a cabo el siguiente día, el Día de Todos los Santos, aunque no se sabe en qué año ocurre, puesto que, como ya se ha señalado, la crónica es 
caótica y confusa. Lo que sí sabemos es que su muerte fue muy sentida por todos en el Reino, especialmente en las casas de Pioz y Polvoranca, que en un tiempo estuvieron divididas por rencillas. La confusión cronológica es una de las anomalías que se manifiestan a lo largo de la historia, comenzando con las pompas fúnebres del infortunado señor de Polvoranca ${ }^{36}$. Se unen aquí los más diversos personajes en una alucinante caminata en la que marchan:

Los lacayos de la casa de Polvoranca, vestidos a la borgoñona... los niños del Hospicio... el Capitán general, llevando a su derecha a dos señores senadores y a su izquierda a D. Beltrán de Pioz, que había sido virrey del Perú, al Inspector de la Santa Hermandad, y al... subsecretario del Santo Oficio. Iban también todos los individuos de la Junta Directiva del Ateneo, presididos por el Prior de la Merced, la

\footnotetext{
${ }^{36}$ Vemos aquí un interesante paralelo con la teoría de relatividad de Einstein. El conocido físico teórico, Brian Greene, describe la relación entre ambas variables de la siguiente manera:

Just as we envision all of space as really being out there, as really existing, we should also envision all of time as really being out there, as really existing, too. Past, present, and future certainly appear to be distinct entities. But as Einstein once said, "For we convinced physicists, the distinction between past, present, and future is only an illusion, however persistent." The only thing that's real is the whole of spacetime. In this way of thinking, events, regardless of when they happen from any particular perspective, just are. They all exist (Greene 139). Curiosamente, en la imaginación dialógica bajtiniana se define el cronotopo como "espacio tiempo". Este término se emplea en matemáticas como parte de la Teoría de la Relatividad de Einstein, y expresa la inseparabilidad del espacio y el tiempo (el tiempo como la cuarta dimensión del espacio). En el cronotopo literario los indicadores espaciales y temporales se funden en uno. El tiempo, por así decirlo, se espesa, se encarna, se convierte en algo artísticamente visible, del mismo modo, el espacio responde a los movimientos de tiempo de la trama y la historia.
} 
oficialidad del tercio de Sicilia... lo más granado de la Sociedad Protectora de los Peces, algunos consejeros de Indias y de órdenes, y toda la plana mayor del Consejo de Administración del Ferrocarril de Turris a Utopía. La venerada Archicofradía del A. B. C... cubiertos los cofrades con ropa negra de penitente y capuchón colorado, y detrás seguían los masones, tan respetables con sus mandiles, que se confundían con los padres dominicos. (296)

Si examinamos este anacrónico desfile desde la perspectiva de la tradición hermética, descubrimos cómo va preparándose el terreno para el peregrinaje que emprenderán nuestros personajes principales. Aquí no existen límites ni fronteras de tiempo ni espacio; solo existe un "ahora", que Galdós utiliza para crear una atmósfera de movimiento continuo por donde se cuelan escenas pertenecientes al medioevo y a los siglos XVI, XVII y XVIII, coexistiendo con el presente decimonónico.

En la filosofía hegeliana este constante movimiento tiene su origen en la idea absoluta, la cual evoluciona a causa de sus aspectos compositivos, es decir, la fluidez de los pensamientos o conceptos que inevitablemente se mueven fuera de sí hasta llegar a su antítesis, para luego regresar a sí mismos, pero en un nivel o estado superior, y así constituir círculos de movimiento propio (Abrams, Natural Supernaturalism 226). Ese movimiento periódico es lo que Hegel caracteriza como la "temporalización" del espacio y "espacialización" del tiempo. El tiempo es el momento infinito (en otras 
palabras, la sucesión sin fin, la transitoriedad, la otredad) y el espacio es el momento de la identidad propia (ya que cualquier punto en el espacio puede considerarse fijo en la eternidad). La unión de estos dos momentos es una imagen externa de la conciencia, y la totalidad de los mismos permite que podamos determinar y medir el tiempo (Harris 244). Cabe notar que en el texto hermético, Asclepios, se dice que todas las cosas están sometidas a la ley del tiempo: "aunque la eternidad sea estable, inmóvil y fija... el curso del tiempo, que es móvil... siempre es traído de nuevo a la eternidad, y este movimiento... es una revolución cíclica [entonces] resulta que la eternidad misma, parece estar a su vez en movimiento a causa del tiempo" (Los libros de Hermes Trismegisto 174). Visto desde otra perspectiva, podría decirse que, "el devenir es un cambio en calidad y en cantidad; todo movimiento material es un nacimiento" (Los libros de Hermes Trismegisto 106). Así, el hecho de que el movimiento periódico ofrezca la totalidad de estos momentos, (es decir, concretamente, hace que podamos determinar y medir el tiempo) es de suma importancia (Harris 244).

Hegel concibe la Naturaleza como algo que contiene dentro de sí un "movimiento en reposo", que consta de cuatro dimensiones: tres espaciales y una temporal (Magee 101). Esta concepción nos explicaría, la unidad del espacio y del tiempo, es decir, de un punto específico y de un momento específico, como la representación del movimiento por donde se colarían estos disímiles personajes y eventos. Y es a raíz de esta confusión ambiental que en la historia de "Celín" comienzan a ocurrir cosas extrañas que desafían 
los límites de lo que comúnmente conocemos como "realidad". Utilizando la figura del supuesto cronista de las casas de Pioz y Polvoranca, Galdós justifican "los aspectos más conflictivos del cuento" (Ezama Gil, "El manuscrito" 89-90). De hecho, el narrador nos advierte que, "el año de esta desgracia no consta en la Crónica, ni hay posibilidad de fijarlo, porque todo el documento es pura confusión en lo tocante a cronología, como si el autor hubiera querido hacer mangas y capirotes de la ley del tiempo" (Pérez Galdós, "Celín” 294).

Como sabemos, Diana de Pioz, sintió tal dolor ante la muerte de su novio que, abatida y desconsolada, le sobreviene la idea de quitarse la vida lanzándose al río Alcana. Mas la oscuridad de la noche y "la extensión laberíntica de la gran ciudad" no permiten que encuentre el camino (306). caos noctívago se acentúa con el redoble de "las campanas de todas las iglesias, así como las de las sociedades literarias y científicas" que "atronaban el aire con sus fúnebres lamentos" $(301)^{37}$. Deambulando por la ciudad, Diana ve "mujeres que no parecían trigo limpio, y hombres que las seguían", oye "ruido de espuelas" y ve caballos a toda marcha; aturdida observa "muchas tabernas y gente de malos modos y peores palabras". También ve "pasar una gran torre que iba de Norte a Sur" mientras "sonaban en ella las campanas" y "fábricas monstruosas con altísimas chimeneas" y "hombres encapuchados, que debían de ser la ronda del Santo Oficio",

\footnotetext{
${ }^{37}$ Resulta absurdo pensar que las de las sociedades literarias y científicas también se oían sonar, ya que estas instituciones no se distinguen por tocar campanas.
} 
penitentes y empleados del resguardo, y hasta "un borracho que trazaba con inseguro paso rúbricas sin fin en el suelo húmedo" (309-10).

En medio de la confusión, Diana encuentra a un chiquillo al que pregunta la ruta hacia la iglesia. El pequeño, como de unos seis años, responde: “¡El Buen Fin! Muy cerca está. ¿Ves aquella torre que acaba de parar?... Allí es. Yo te enseñaré el camino" (310). El niño, "con marcial continente", estaba vestido con ropas raídas y descalzo, pero a pesar de su pobre vestimenta no tenía frío (311). Diana le ofrece un ducadito de once reales si le sirve de guía, y en el camino la joven aprovecha para interrogarlo, haciéndole toda suerte de preguntas. El chico contesta que su nombre es Celín (nombre que alude al diminutivo de "cielo") y que su padre vive en una "estrella", mientras brinca a "alturas increíbles". Diana no puede más que exclamar asombrada: "Chiquillo, pareces un pájaro", lo cual no deberá pasarse por alto (313). Este símil nos da la clave de la verdadera identidad de Celín, quien, también exhibe un comportamiento regido por el movimiento constante.

De esta manera comienza el viaje de los personajes a través de la Naturaleza de la región de Turris, un recorrido que hará que Diana vaya conociéndose a sí misma y adquiriendo un conocimiento que le proporcionará poder y control sobre su vida. Celín lleva a Diana por caminos que le harán trascender esa mundana naturaleza y convertirse en dueña de su propio destino. Al inicio de este itinerario podemos advertir una desconexión en la energía vibratoria de Diana, puesto que desea acabar con 
su vida, sin embargo, al tomar la decisión de suicidarse, esta pone en marcha una serie de acontecimientos que la traerán de vuelta al punto de partida, esta vez transformada física y espiritualmente.

Al comienzo de su narración, el cronista relata que "Diana consideraba la humana existencia... como una esclavitud cuyas cadenas son la grosería y la animalidad!" (303). Si buscamos en la tradición hermética la concepción del cuerpo físico, encontramos que se considera un conjunto de sistemas que vibran en la misma frecuencia; los pensamientos, las emociones, los deseos y los impulsos son estados vibratorios. Como ya hemos visto, este principio supone que todo está en movimiento, nada permanece inmóvil, las diversas manifestaciones de la materia, de la fuerza, de la mente y del espíritu, son el resultado de diferentes estados vibratorios. La chica, ponderando los sucesos, llega a la conclusión de que "sería su cuerpo todo lo sutil e impalpable que se quisiera; pero cuerpo tenía que ser, aunque con sólo medio adarme de materialidad", y fantaseaba con unirse a los despojos de su amado. Pensaba que así fundiría la esencia de su ser con la de quien en vida fue Galaor, mas "esta confusión de huesos no podía la joven concebirla sino admitiendo que los tales huesos [sic] debían de tener conciencia de sí mismos, que los cráneos se reconocían pensantes" (Pérez Galdós, 318-19). Es decir, que de no poder reestablecer la conexión con la conciencia de su amado después de la muerte, de nada valdría suicidarse. Aun así, luego de cavilar sobre los estragos de la muerte en aquella capilla dedicada al Espíritu Santo, "la inconsolable se levantó decidida a abreviar el 
tiempo que la separaba de la muerte" (319). De esta manera se dirigen en busca del río Alcana, no sin antes Diana pedir a Celín que guarde su secreto y a cambio le dará más dinero. Celín accede, no obstante le informa a la joven que "el río estaba aquí esta tarde, pero se pasó ya a la otra banda. Le vi correr, levantándose las aguas para no tropezar en las piedras y echando espumas por el aire" (314).

No debemos olvidar la advertencia del cronista acerca del carácter errante del río que baña los bordes de la ciudad de Turris, por lo que el viaje en busca del mencionado cuerpo de agua será largo y tortuoso. Si atendemos la filosofía hegeliana, la cual traza el desarrollo espiritual progresivo hasta llegar a una etapa de madurez, vemos una analogía con el viaje de los protagonistas de la historia. Para Hegel, el espíritu se educa a sí mismo y recorre un metafórico camino hacia el conocimiento o "Bildungsweg". Al final de este camino, el espíritu experimenta el renacer a una nueva identidad (Abrams 228, 231). Este volver a sí mismo del espíritu, puede considerarse como su meta suprema y absoluta; a esto, simplemente, es a lo que el espíritu aspira y no a otra cosa, ya que: "Todo lo que acaece en el cielo y en la tierra ---lo que acaece eternamente--- la vida de Dios y todo lo que sucede en el tiempo, tiende solamente hacia un fin: que el espíritu se conozca a sí mismo, que se haga objeto para sí mismo, que se encuentre" (Hegel, Lecciones sobre la historia de la filosofía 28). Al espíritu regresar a sí mismo alcanza su libertad, pues solo es libre lo que no se refiere a otra cosa ni depende de ella. Así, por ejemplo, cuando intuimos, 
cuando sentimos, estamos determinados, no somos libres; solo lo somos cuando adquirimos la conciencia de estas sensaciones. De esta manera podemos establecer una comparación entre el camino recorrido por Diana y el camino que el espíritu debe recorrer para llegar a conocerse, y al conocerse, llega a conocer a Dios. Recordemos que, en términos herméticos, Dios requiere de su creación para realizarse. Pero no solo requiere que toda su creación lo reconozca, sino que específicamente necesita que el ser humano sea quien desempeñe este papel tan crucial. En el discurso a su hijo, Tat, Hermes declara que: "Dios no ignora al hombre, por el contrario lo conoce y quiere ser conocido por él. La única salvación del hombre es el conocimiento de Dios" (Los libros de Hermes Trismegisto 107). En otras palabras, somos parte de una conciencia eterna, de la conciencia que creó el universo. Entramos en el proceso de creación y vamos aprendiendo por medio de los distintos niveles del proceso de crecimiento del alma.

Es significativo el hecho de que en la ciudad de Turris no solo cambien los lugares de sitio, sino que también cambie el extraño muchacho. El hermetismo lo expresaría en términos de vibración y movimiento. Al manifestarse Celín en la vida de Diana se da un cambio de conciencia y la oscilación del péndulo comienza a marcar un compás vital. Descubrimos cómo el principio del ritmo o movimiento trabaja en conformidad con el principio de la vibración. El kybalión nos explica que desde "el todo" o motor universal, hasta la más pequeña forma de materia, todo vibra: "La vibración del espíritu es de una intensidad infinita; tanto, que prácticamente puede 
considerarse como si estuviera en reposo. Por ejemplo, si nos fijamos en una rueda inmóvil y luego mirarmos esa misma rueda que se mueve a cientos de revoluciones por minuto, parecería estacionaria (86-88).

Teniendo en cuenta estas características vibratorias, podríamos entender cómo poco a poco Diana va percatándose de las variaciones físicas y de las extraordinarias características de su lazarillo: "O es que la claridad agranda los objetos, o tú, Celinillo, has crecido... ¡Qué estirón has dado, hijo! Si casi casi me llegas al hombro" (Pérez Galdós, "Celín" 320). Con el crecimiento físico de Celín, va registrándose un cambio espiritual y emocional en Diana. La voz de Celín había adquirido un tono más grave, por lo que la joven "sintió cierto estupor" (330). La figura del niño-hombre va adquiriendo un carácter transformador, y en el camino hacia el suicidio, la desconsolada joven va olvidando la tristeza. De manera semejante, la filosofía hegeliana detalla el proceso de crecimiento que debe sufrir el espíritu para llegar a la culminación de su aprendizaje: El espíritu no permanece quieto, sino que se halla siempre en movimiento. Pero, así como en el niño, tras un periodo de gestación, "rompe bruscamente la gradualidad del proceso puramente acumulativo en un salto cualitativo, y el niño nace, así también el espíritu que se forma va madurando" (Hegel, Filosofía del espíritu 7).

El espíritu sufre asombrosas metamorfosis según experimenta eventos inexplicables o diversas formas de conciencia, o múltiples personas o espíritus particulares. El espíritu es también su propio antagonista, que

${ }^{5}$ Curioso es el nombre de la Iglesia del Buen Fin, ya que se presta a una doble interpretación: Iglesia de "el buen propósito" o Iglesia de "la buena muerte". 
aparece en multitud de disfraces, por lo que el actor interpreta todos los personajes en el drama. En una ironía dramática, sin embargo, el espíritu lleva a cabo esta actuación asombrosa sin saberlo (Abrams 192). De ahí que Diana: "No recordaba... haber respirado nunca un aire tan balsámico y puro, tan grato a los pulmones, tan estimulante de la vida y de la alegría y paz del espíritu" (Pérez Galdós, "Celín” 334). La Naturaleza no cesa de mostrar sus maravillas, poniéndolas a la disposición de Celín y Diana, y les vemos disfrutando idílicamente, como si Galdós, emulando la historia de la creación divina, les hubiera colocado en un edénico entorno. Al llegar al río de aguas muy claras y de poco fondo, Diana le pide a su lazarillo que la lleve a un lugar más profundo, pero Celín, la distrae, la guía por otro sendero, y le ofrece moras y los frutos del improbable "árbol de café con leche" (326-27).

Observa Hegel en su Filosofía del espíritu que "el entendimiento... va y viene a través de toda la materia y todo el contenido apoyándose en estos elementos, que lo mantienen en cohesión y le dan su posición dominante" (51). Visto desde esta perspectiva, podemos comprender cómo la transformación de Diana la lleva de un extremo emocional a otro enteramente diferente. El principio hermético de vibración puede verse operando en su estado anímico, y la hace ascender en la escala de intensidad vibratoria. Estando la materia en esta constante vibración, y siendo el espíritu parte inherente de la creación, verificamos que todo

\footnotetext{
${ }^{6}$ No debemos pasar por alto la propuesta de Alan E. Smith que plantea que Galdós "recrea el mito bíblico del Edén, aquí subvertido, pues comer del fruto del árbol del café con leche, subir al árbol de la vida, y caer en el placer sexual, no provocan el castigo, sino la salvación" (32).
} 
pensamiento, emoción o estado mental tiene su grado y modo de vibración correspondiente entonces que no es casualidad que Diana sienta "una alegría loca" junto a Celín (Pérez Galdós 338).

En determinado momento, y enfrentados al reto que presenta un caudaloso trecho del Alcana, Celín toma a Diana en brazos "como si fuera una pluma", causándole gran asombro a la chica. Diana comienza a notar una transformación física en su persona: "La risa le retozaba en los labios" y "sus ideas habían variado"; su indumentaria había cambiado "se vio el cuerpo ceñido con jubón ligero, los brazos al aire, la garganta idem per idem" (33335). Utilizando el principio de vibración, y aplicándolo a los fenómenos mentales, uno puede polarizar su mente en cualquier grado que desee, consiguiendo así un control sobre sus estados mentales, y del mismo modo puede afectar las mentes de otros, produciendo en ellos los estados mentales deseados (El kybalión 86-88). Mediante un esfuerzo de la voluntad de la persona, o de otras personas, estos estados mentales pueden reproducirse, igual que un tono musical puede ser reproducido al hacer vibrar un instrumento a una cierta frecuencia. Diana gozando el momento, siente que el pasado se aleja de su memoria y el presente consiste solo en la felicidad que Celín le desvela mediante la Naturaleza. Y es esa naturaleza en la obra galdosiana la que constituye una guía de las posibles soluciones para los conflictos de la vida, puesto que podemos así, leer y descifrar los secretos del cosmos (Correa 234-35). De modo que, conforme avanza el relato, vemos que Celín logra disuadir a Diana de suicidarse y la invita a vivir 
una vida nueva, y que la naturaleza, cómplice silente del travieso Celín, se les presenta en todo su esplendor. Las aguas del río Alcana ya no representan un destino fatal, sino que traen: "pececillos de todos colores... crustáceos y caracoles monísimos. Las arenas de oro se mezclaban con el limo blando y verde, y en algunos sitios brillaban al sol como polvo luminoso... y admiraron ejemplares peregrinos de la flora acuática" (333).

Es esta naturaleza la que acelerará el proceso de transformación espiritual de nuestra protagonista, por lo que "Celín pondrá a Diana... en contacto con la naturaleza para apartarla de sus espiritualismos falsos y de sus proyectos de autodestrucción que van contra natura" (De la Nuez 194). Atravesando hermosos parajes, admirando paisajes de indescriptible belleza e interactuando con las maravillas naturales a las que Celín la expone, Diana, quien curiosamente lleva el nombre de la mitológica diosa de los bosques y la caza, abandona su antiguo ser, tal como algunos animales mudan su piel.

En la metamorfosis de este personaje galdosiano vemos un reflejo del pensamiento hegeliano que sostiene que al trascender la naturaleza nos convertimos en dueños de nuestro propio destino mediante la adquisición de conocimiento, ya que es esa naturaleza "la idea que sale de sí misma, se exterioriza para llegar... a retornar a sí, a interiorizarse en el pensamiento del hombre. Por tanto, el devenir de la Naturaleza es una ascensión hacia el Espíritu" (Serreau 34). Hegel explica el proceso por el cual el espíritu finalmente se encuentra ante su propia conciencia en forma objetiva, a lo que 
llama Wissenschaft o ciencia, que aunque eterna, no aparece en el tiempo ni en la realidad hasta que el propio espíritu llega a un estado de conciencia propia: La meta suprema y absoluta del espíritu es volver a sí mismo. Todo lo que acaece en el cielo y en la tierra... tiende solamente hacia un fin: que el espíritu se conozca a sí mismo, que se encuentre, devenga para sí mismo, que confluya consigo mismo (Lecciones sobre la historia de la filosofía 46).

En el peregrinaje de Diana y Celín podemos ver un paralelismo con la dialéctica hegeliana, la cual se puede resumir en tres palabras: tesis, antítesis y síntesis (aunque Hegel no utiliza expresamente estas acepciones para describir su sistema). La tesis es el concepto establecido acerca de determinado asunto, la cual da paso a un conflicto o fuerza opositora, la antítesis, para luego de la lucha entre ambas nociones, surgir algo nuevo y superior: la síntesis. Podría decirse que es una visión circular, ya que lo último nos refiere a lo primero. Para una mejor comprensión de esta idea, Hegel nos presenta el ejemplo del amo y el esclavo. El amo es amo ya que posee un esclavo, entonces el amo depende del esclavo para que reafirme su identidad. El amo es esclavo de su esclavo y el esclavo es el amo de su amo.

La dialéctica hegeliana, tomando como base el hecho de que todo en el universo es movimiento y cambio, que no hay nada aislado, sino que todo depende de todo, propone la idea del movimiento dialéctico del mundo, comenzando con el movimiento del pensamiento, porque representa el progreso del espíritu. Hegel da principal importancia al espíritu y, por tanto, 
cree que son los cambios de este, los que producen los cambios en la materia.

Para Hegel, el universo es la idea materializada, pero es el espíritu el que descubre el universo. Comprueba, sin embargo, que el espíritu y el universo están en perpetuo cambio y llega a la conclusión de que las mutaciones del espíritu determinan los cambios de la materia. Así, la cercanía de Celín hace que Diana reconozca su transfiguración y comprenda que no tiene sentido acabar con su vida solo porque D. Galaor ya no se encuentre en este mundo.

Una de las maneras en que Celín logra transformar la vibración negativa de Diana es mediante los sueños. En determinado punto del camino, los jóvenes suben a un gran árbol al caer la noche, y la chica, quedándose dormida en brazos de Celín, tiene un vívido sueño en el que se encuentra en la tribuna del Senado oyendo a su padre pronunciar un gran discurso a favor del "encauzamiento y disciplina del río Alcana". Quería este que se le "amarrase con gruesas cadenas o que se le aprisionase en un tubo de palastro", mas esta absurda propuesta hizo que todo el mundo se echara a reír (339-40). El río, posible representación del reclamo de libertad y del torrente erótico que impulsan a su hija hacia la adultez, se le va de las manos al inflexible padre. El hecho de querer amarrar el río con gruesas cadenas manifiesta el deseo de alcanzar lo imposible, de ir en contra de las leyes de la Naturaleza. Una vez el movimiento de la Naturaleza se pone en marcha, no hay manera de detenerlo, pues obedece a la necesidad de crecimiento y 
evolución de todo elemento dentro de la creación, y ese "movimiento del mundo y de todo animal material no viene de fuera, sino que es producido desde dentro hacia fuera del alma, por el espíritu o algún otro principio incorpóreo" (Los libros de Hermes Trismegisto 18).

Finalmente Diana despierta riendo en los brazos del hermoso mancebo. El chico abrió los ojos, "que fulguraban como estrellas, y la contempló con cariñoso arrobamiento", pero la joven de Pioz, "al verse de tal modo contemplada, sintió que renacía en su espíritu, no el pudor natural, pues este no lo había perdido, sino el social hijo de la educación y del superabundante uso de la ropa que la cultura impone", mientras que la escasa vestimenta de ambos causa en Diana un enorme susto (Pérez Galdós, "Celín” 341). Luego de reconocer su casi desnudez, los jóvenes caen abruptamente del árbol. La interrupción del narrador en este punto de la historia para indicar la gran consternación expresada por el cronista, que del susto rompe una gran cantidad de botellas que en su mesa reposaban, resulta de suma importancia: "el chasquido del vidrio al saltar en pedazos le sugirió sin duda la idea de que los cuerpos de Celín y Diana habían rebotado en cascos menudos como los botijos que se caen de un balcón a la calle" (Pérez Galdós 342). Smith ha visto aquí un "sincrónico orgasmo" con el que se representa la caída de Adán y Eva en el pecado, aludiendo a la interpretación freudiana "cuando una mujer sueña que 'cae' suele esto tener, casi siempre, un sentido sexual" (104-05). Pero luego se recompone el cronista y relata que Diana despierta (nuevamente) esta vez en su alcoba y: 
"dio un grito, y se reconoció despierta y viva, reconociendo también con lentitud su estancia, y todos los objetos en ella contenidos. Parece que aquí debía terminar lo maravilloso que en esta Crónica tanto abunda; pero no es así" (342-43).

El recurrir al mundo de lo onírico es una característica común en la literatura galdosiana. El uso de esta técnica permite que Galdós revele abiertamente los impulsos sexuales, las frustraciones y las flaquezas de los personajes en sus obras. ${ }^{38}$ Como bien señala Schraibman en su estudio sobre los sueños en la obra galdosiana, en la España de finales del siglo XIX la superstición y la fuerte creencia en poderes mágicos y proféticos de seres sobrenaturales eran parte importante en las vidas de las masas, por lo que Galdós "employed the technique of the dream device to acquaint his readers with this aspect of the intellectual climate of his time" (184). Ezama Gil plantea también, que en Galdós “los sueños y otros estados de conciencia próximos a lo onírico son, asimismo, característicos de la protagonista femenina; la ambigüedad de tales estados se refleja en una desconcertante vacilación entre pasado y presente, sueño y realidad" ("El manuscrito" 93). Además, los sueños ofrecen al autor la oportunidad de expresar sus opiniones acerca de temas considerados tabú en la época (Schraibman 181, 182).

\footnotetext{
${ }^{38}$ De acuerdo a Smith "Lo original y característico de Galdós es el rechazo del oprobio moral que la caída invoca en cultura judeocristiana... Este orgasmo simbólico revindica la sexualidad femenina, y, en última instancia, también la del hombre" (104-05).
} 
La chica parece comprender que todo ha sido un sueño mas, luego escucha un arrullo semejante al de las palomas, y acto seguido ve un gran pichón revoloteando contra el techo y las paredes, que luego se posa en su hombro y le pregunta:

¿No me reconoces? Soy el Espíritu Santo... me encarné en la forma del gracioso Celín, para enseñarte, con la parábola de Mis edades y con la con contemplación de la Naturaleza, a amar la vida y a desechar el espiritualismo insubstancial que te arrastraba al suicidio... Estáis en el mundo los humanos para gozar con prudente medida de lo poquito bueno que hemos puesto en él, como proyección o sombra de nuestro Ser. (343)

El sueño dentro de otro sueño muestra una serie de cambios en la estructura del ego que son más complejos de lo habitual. La teoría freudiana clásica considera que los sueños están disfrazados, de modo que un sueño lógicamente podría pensarse que es una versión disimulada de lo oculto, de lo "latente". Estos sueños tienden a ejemplificar una verdad que pocas veces se aprecia: este proceso se asemeja a la creación de un "nuevo mundo", no solo una revisión del ego en su mundo actual. No solo cambia el ego, sino que toda la estructura del "mundo" se altera, incluyendo el papel que desempeñan otras personas (Hall 89-90). De esta manera, Galdós concluye el "círculo" recorrido por Diana, quien ha pasado por un proceso de crecimiento espiritual, de acorde a sus creencias. Celín, el "hijo" enviado por un "padre" que vive el las alturas celestiales, crece físicamente, al tiempo que 
Diana crece en el plano espiritual, y al final de la jornada, se materializa el "espíritu" en forma de ave parlante. He aquí, la trinitaria unidad que descubre a la chica su misión existencial. ${ }^{39}$

En la filosofía hegeliana, la exposición racional de la teología trinitaria es la máxima tarea de la filosofía. En esta explicación se identifican las personas de la Trinidad con las tres fases de la especulación-dialéctica: Dios el Padre es el pensamiento absoluto, la idea de la filosofía expuesta en la metafísica. Dios el Hijo es la vida divina del universo finito, expuesta en la filosofía de la naturaleza, y Dios el Espíritu Santo es la totalidad de la especulación, el movimiento conceptual a través del cual la vida del mundo recibe su explicación racional (Harris 155).

La prueba hegeliana de la existencia de Dios no depende de lo finito o subjetivo. Por el contrario, se basa en el concepto de lo infinito. De este modo, se puede construir una prueba ontológica que no se fundamente en nuestra idea subjetiva de Dios o de cualquier otro concepto finito (Calton 61). Puede deducirse entonces que en las entrañas de la eternidad se reporta un

${ }^{39}$ Son varias las alusiones que Galdós hace a la tercera persona de la Trinidad, mediante detalles relatados por Díez de Turris:

La imagen de la paloma campeaba en el escudo de la familia y era emblema, amuleto y marca heráldica de todos los Pioces que habían existido en el mundo. La paloma resaltaba esculpida en las torres vetustas y en las puertas y ventanas del palacio, tallada en los muebles de nogal, bordada en las cortinas, grabada con cerco de piedras preciosas en la tabaquera del marqués, en los anillos de Diana, en todas sus joyas, y hasta estampada por el maestro de obra prima en las suelas de sus zapatos. Diana tenía costumbre de invocar a la tercera persona de la Trinidad en todos los actos de su vida, así comunes como extraordinarios, por lo cual en esta tremenda ocasión que acabo de mencionar, convirtió la niña su espíritu hacia la paloma tutelar de los ilustres Pioces, y después de una corta oración, se salió con esto: "Sí, pichón de mi casa, tú me has inspirado esta sublime idea, tuya es, y a ti me encomiendo para que me ayudes" (Pérez Galdós 303). 
movimiento, y esa movilidad se estabiliza gracias a la inmutabilidad de la ley que regula su curso. De esta manera se puede afirmar que también Dios se mueve aun permaneciendo inmóvil (Los libros de Hermes Trismegisto 174). Así, nuestra protagonista recorre la ruta que la trae de vuelta a sí misma. El doble despertar de Diana resulta extraordinario si lo que se pretende es contar un relato basado en los dislates del embriagado historiador de Turris. Hegel había discernido ya que en el caos, la confusión y el flujo de los sueños, los límites fijos de la subjetividad se disuelven. Al contrastar el sueño y la vigilia, "Hegel characterizes the former as the division of oneself from oneself, whereas the latter is the covering of oneself in oneself" (Wolfson 7576). En el cuento de Galdós, la peregrinación de Diana la lleva en un viaje de reencuentro consigo misma, al ser conducida por Celín en un educativo viaje espiritual, el cual concuerda con la descripción de la jornada tortuosa que describe Hegel en su filosofía del espíritu, ya que:

in a literal sense [this journey is] a spiritual history. It is in other words, a biography of the "General Spirit", representing the consciousness of each man and Everyman, the course of whose life is painfully self-education rendered in the plot-form of circuitous journey from an initial self-division and departure, through diverse reconciliations and ever renewing estrangements, conflicts, reversals, and crises of spiritual death and rebirth. (Abrams, Natural Supernaturalism 229-230)

En conclusión, en el momento en que Diana decide suicidarse, esta 
pone en marcha una sucesión de acontecimientos que la traerán de vuelta al lugar de partida, pero transformada física y espiritualmente, y con una nueva visión ante el significado de la vida. Comprende el error en el que había caído al haberse negado a reconocer que ante ella se abrían "nuevos horizontes" hacia los que debía avanzar. Visto desde el punto de vista hermético-hegeliano, el objetivo de la búsqueda de conocimiento por parte del espíritu (de acuerdo a la metáfora hegeliana de la peregrinación vital) "is the return to the home it has left at the beginning; its home, however, turns out to be where the spirit has been all along, without knowing it" (Abrams, Natural Supernaturalism 234). El conocimiento de la Naturaleza al cual expone Celín a la protagonista causa en esta la transformación necesaria que la hace escoger el camino de la vida. Dicho en términos herméticos, Celín conduce la mente de Diana hasta la vibración deseada, logrando que esta se polarice hacia el extremo positivo de la escala vibratoria. De esta manera, los principios herméticos de la vibración y el ritmo trabajan al unísono para cambiar un estado mental y espiritual en extremo negativo. En el próximo capítulo veremos cómo otro principio hermético, la polaridad, desempeña un papel importante en este proceso. 


\section{CAPÍTULO IV}

Póstumo, transmigrado y envirginiado: Paradoja divina y creación generadora

Por lo pronto, ni sé ni he logrado saber nunca de donde vengo. Si he vivido en otro u otros mundos, bebí sin duda las aguas del Leteo, puesto que de nada hago memoria.

Alejandro Tapia y Rivera

Life has its own hidden forces, which you can only discover by living.

Soren Kierkegaard

Póstumo el transmigrado: historia de un hombre que resucitó en el cuerpo de su enemigo (1872), y Póstumo envirginiado o historia de un hombre que se coló en el cuerpo de una mujer (1882) de Tapia y Rivera cuentan el atrabancado peregrinaje espiritual del personaje central de ambas narraciones. La historia del Transmigrado se desarrolla hacia mediados del siglo XIX en la gran ciudad madrileña, donde impera un asfixiante ambiente burocrático y donde todavía la rigidez moral del androcentrismo y el poder de la Iglesia abogan por el carácter exclusivamente doméstico de la mujer en la sociedad.

La acción comienza cuando a Póstumo, enamorado de la bella Elisa de Doble Anzuelo, le sobreviene una fiebre que lo lleva al cementerio unos pocos días antes de su casamiento (589). Pero el difunto se reconoce vivo antes de ser enterrado, y negándose a la muerte, su espíritu no abandona la materia. Mientras tanto, Elisa ---ya muy repuesta de su pérdida--- sale para una fiesta de carnaval con Sisebuto, quien, habiendo sustituido a Póstumo en su puesto de trabajo, intenta sustituirlo también en el corazón de la joven. 
Póstumo va al encuentro de estos, y ya en el salón de baile se arma un gran revuelo cuando se descubre que se ha colado un muerto y unos guardianes celestiales lo obligan a regresar al cementerio. Lo entierran nuevamente y al fin abandona su cuerpo. Sin embargo, alma inquieta al fin, Póstumo pide regresar a la tierra para vengarse de su novia y de su "amigo" sin olvidar su identidad pasada. Sisebuto, quien había logrado el objetivo de casarse con Elisa, muere al rompérsele un vaso cerebral mientras discute con Elisa y la madre de esta. Póstumo aprovecha la oportunidad para reencarnar justo cuando iba a realizarse la autopsia del cuerpo de su rival. Elisa, gracias a sus conocimientos espiritistas, reconoce a Póstumo en el cuerpo de Sisebuto, se casan y comienzan una nueva vida, no obstante, cada vez que Póstumo se mira al espejo y ve la imagen de Sisebuto, se abofetea sin piedad, hasta comprender que debe reconciliarse con su nuevo cuerpo. Elisa queda embarazada, y Sisebuto reencarna en el niño (al que llamaron Postumito) para hacerles la vida imposible.

Don Perpetuo Paquidermo, condenado a vivir eternamente, comienza a frecuentar a Elisa. Póstumo le pide cuentas y es sacado a patadas del lugar. Entonces decide matar a su esposa por haberlo deshonrado, mas ella logra huir. Póstumo se suicida tirándose de un segundo piso, y su cuerpo queda destrozado. Su espíritu llega al más allá sin querer volver a este mundo ni a ningún otro, por lo que pide al Custodio el don de olvidar todo lo sucedido. Otros espíritus, entre ellos, el de Cervantes, lo consuelan. Más tarde llegan Elisa, Sisebuto, don Cósmico (quien había transmigrado sin 
beber de las aguas del olvido) y don Horóscopo (quien había regresado al mundo con la facultad de conocer el porvenir). Todos concuerdan en que las cosas están bien como están hechas y se consuelan viendo rabiar a don Perpetuo, quien no puede morir.

Entre la publicación de la primera y la segunda parte de esta obra transcurren diez años, y a pesar de que el propio Tapia calificó al Envirginiado como continuación del Transmigrado, parte de la crítica temprana no vio más denominador común que el alma errante y osada de aquel que en su vida terrenal fuera un incorregible soñador llamado Póstumo. ${ }^{40}$ Elsa Castro Pérez lo ilustra al señalar que ambas novelas difieren en el tono, ya que en la segunda "la sátira" y la "comicidad picaresca" desaparecen. El humor que se utiliza en el Transmigrado para criticar la sociedad de la época, "en el Envirginiado se limita a un aspecto y se presenta seria y elevada de miras" (341). Manuel García Díaz plantea, no obstante, que ambos Póstumos poseen "el mismo colorido", aunque en su estilo haya diferencia (127). Mientras que Rafael Bernabé Riefkohl propone que "en Póstumo el transmigrado la risa... prepara... el terreno para el cuestionamiento de todas las categorías y formas sociales y,

\footnotetext{
${ }^{40}$ Desde el momento en que leemos el título de la obra nos damos cuenta de que el nombre del protagonista guarda una estrecha relación con lo que habrá de desarrollarse. La Real Academia Española define el término "póstumo" como "que sale a la luz después de la muerte del padre o autor". Curiosamente, este fue el caso de la segunda parte de la novela: Póstumo el envirginado. El término generalmente era usado para referirse a los hijos nacidos después de la muerte del padre o la madre, por lo que se conocían como "hijos póstumos". Más tarde se incorporó a la literatura para referirse, de igual manera a las obras que fueron publicadas después de la muerte del autor. La palabra está compuesta del prefijo "post" (después) y "humus" del verbo "humare" (enterrar).
} 
específicamente, para las reflexiones feministas de Póstumo envirginado" (248-49). Si bien es cierto que ambas partes difieren en el estilo y en el tono jocoso del primer Póstumo que Marta Aponte Alsina ha catalogado de comedia tipo "slapstick", no debe perderse de vista que tanto la historia del Transmigrado como la del Envirginado comparten ese espíritu dual e inquieto del personaje principal. Es por eso que, en mi opinión, la primera y la segunda parte están conectadas por lo que Román-Eyxarch plantea es el deseo del individuo de alcanzar la perfección y la armonía espiritual; el objetivo "no es partir de un pasado, éste importa, pero la propuesta aquí es la de un futuro esperanzador y de una verdad transformadora para un presente" $(120-21)$.

Desde el centenario de la muerte del autor, algunos estudiosos han reexaminado la saga de Póstumo, y han propuesto nuevas lecturas acerca de la importancia y significado de la obra con respecto a los temas de identidad de género, la construcción y significado del cuerpo, la espiritualidad, el colonialismo y el poscolonialismo (Suko 1). Iris M. Zavala ha señalado que "de entrada hay que notar que la configuración narrativa queda fundamentada sobre el tema del espiritismo" (133). En la historia encontramos episodios en los que "la doctrina espiritista es práctica, creencia y modo de vida de los personajes" (Cruz Rivera 118), y "no queriendo hacer una abierta defensa de teorías que consideraba demasiado adelantadas para su época y su país, utilizó la forma de novela satírica, para criticar aquéllos que las mal interpretaban" (García Díaz 124). 
Tanto el Transmigrado como el Envirginado suelen clasificarse dentro de la novelística, sin embargo, la incorporación de diversos géneros presenta un notable eclecticismo literario. Marta Aponte Alsina plantea que gran parte del diálogo es más análogo en su presentación y función a las formas teatrales que a la novela tradicional. Si la narración pasa del sainete "al melodrama, del docto discurso de exposición científica a la danza macabra" (59), entonces cabe preguntarse cómo clasificar la obra: ¿será una novela política, una novela dramática, una novela filosófica o teórica o simplemente un grupo de textos "excéntricos"? (44). En otras palabras, la polisemia en ambas novelas hace que el texto se preste a una infinidad de interpretaciones (Saldivia-Berglund 41). Partiendo de estas ideas, proponemos un análisis a la luz del precepto hermético de la polaridad, el cual proclama que: "Todo es doble; todo tiene dos polos; todo, su par de opuestos; los semejantes y los antagónicos son lo mismo" (El kybalión 13).

Si miramos al Transmigrado a través del cristal hermético de la polaridad, encontramos que encaja perfectamente con la creencia de que todo cuanto se manifiesta en este mundo tiene "dos lados", "dos aspectos", "dos polos". ${ }^{41}$ La polaridad propone que los opuestos no son sino los dos

\footnotetext{
${ }^{41}$ El cuerpo de la literatura hermética es grande y variado, y escrito con un simbolismo fantástico diseñado para ocultar sus misterios del no iniciado. De acuerdo con Abrams, , sin embargo, podemos trazar un patrón conceptual reiterativo. La ontología básica es ampliamente biológica, y específicamente antropomórfica. Es decir, el hermetismo no estableció la división moderna entre lo animado y lo inanimado, pero aplica las características de los seres vivos a toda la Naturaleza, al tiempo que postula una correspondencia entre lo humano y lo no humano, de tal manera que el ser humano sirve como la forma paradigmática. Los escritos herméticos, por lo tanto, hablan del cosmos como un "macroantropos" y del hombre como un "microcosmos". En este esquema se hace hincapié en la polaridad,
} 
extremos de una misma cosa, consistiendo la diferencia, simplemente, en diversos grados entre ambos. Precisamente, al comienzo de la novela nos encontramos con personajes que parecen ilustrar este concepto, como es el caso del nombre de Elisa de Doble Anzuelo, el cual hace referencia a las relaciones que se desarrollarán alrededor de este personaje (Póstumo y Elisa), (Elisa y Sisebuto), (Elisa y Don Cósmico), (Póstumo-Virginia y Salazar). Sisebuto también conecta con el principio de la polaridad, ya que representa un polo del ente compuesto en que se convierte el alma de Póstumo. Más aún, "en el espacio imaginario del cielo, se advierten las oficinas celestiales del Todopoderoso y en tono satírico, se describen los trámites legales... dentro del mundo oficinesco y represivo", reflejando así la dualidad celestial y terrenal (Zavala 135).

Aponte Alsina señala que el contexto histórico de "reactivamiento de ceremonias secretas y tendencias libertarias" en que se escribe el relato se presta para plantear "el conflicto de la identidad" utilizando el tema del doble, “cristalización simbólica de la contradicción inherente al ser humano" (46). En el siglo XIX la literatura europea trata este fenómeno como resultado del

de los opuestos sexuales y como la fuerza que impulsa todos los procesos naturales. Además, el curso general de las cosas se concibe como un movimiento circular de la unidad en la multiplicidad y, en última instancia, de vuelta a la unidad: Thus "The Poimandres," the first book among the documents of the Corpus Hermeticum (dating from the second and third centuries A.D.), expounds the doctrine that the first Mind, "which is Life and Light," is bisexual, and that when he "gave birth to Man, a Being like to Himself," man was also bisexual. But man fell in love with nature and matter and took up his abode there, and so, together with all living creatures, was divided into two sexes, which proceeded to multiply according to their kind. Nevertheless, if men learn to know that state which was their origin, their minds, after the death of the body, will mount back through the spheres and "enter into God. This is the Good; this is the consummation, for those who have got gnosis. (234) 
creciente estudio psicológico de la división de personalidades. El llamado

Doppelgänger es un motivo psicológico que comprende dos tipos distintos:

(1) el alter ego o doble idéntico de un protagonista que parece ser víctima de un robo de identidad cometido por un ser sobrenatural, y (2) el desdoblamiento de la personalidad o la mitad oscura del protagonista (Faurholt 17). El doble (1846), de Dostoevsky, "William Wilson" (1839) de Edgar Allan Poe, o Frankenstein (1818), de Mary Shelley o, más explícitamente, en el caso del Dr. Jekyll and Mr. Hyde (1886) de Robert Louis Stevenson son ejemplo de este tipo de literatura de tema psicológico (Webber 8).

El tema del doble aparece con el relato del Poimandres, tratado primero del Corpus hermético, en el cual Hermes explica que de todas las criaturas terrestres solo el hombre es un ser doble, puesto que este, queriendo imitar a su creador, se enamora de la Naturaleza y se une a ella. ${ }^{42}$

${ }^{42}$ El Poimandres describe la creación y el deseo del hombre por imitar a Dios de la siguiente manera:

La Mente, el Padre de todas las cosas, siendo Vida y Luz, parió un Hombre igual a ella, a quién amó como hijo propio: porque siendo imagen del Padre era hermosísimo; porque realmente tanto amó el Dios a su propia figura que le entregó la creación entera. Y vio el Hombre la creación en el fuego del Creador, y quiso también crear, y con permiso del Padre entró en la esfera de la creación y, poseedor futuro de plenos poderes, tomó conocimiento de las obras de su hermano, las que lo amaron y le hicieron partícipe de su propia jerarquía. Habiendo así explorado su constitución y participado de sus naturalezas, fue su voluntad desgarrar hacia arriba la periferia de los círculos y contemplar el poderío de aquel que reina sobre el fuego. Entonces poseedor ya de plenos poderes sobre el cosmos de los seres mortales y de los animales irracionales, se inclinó sobre la estructura, y desgarrando el velo mostró a la naturaleza inferior la bella figura del Dios al ver la naturaleza que la figura del Dios poseía una belleza inagotable y las energías todas de los gobernadores, sonrió de amor, pues ya había visto la bellísima figura del Hombre reflejada en el agua, y su sombra sobre la tierra. En cuanto a él, viendo su propia figura en la naturaleza reflejada en el agua la amó, y quiso 
De aquí surgió una condición dual: "mortal por el cuerpo e inmortal por su propia esencia. Inmortal y soberano de todas las cosas, se encuentra sometido al destino que rige lo que es mortal; superior a la armonía del mundo, se encuentra cautivo en sus lazos; macho y hembra como su Padre" (Los libros de Hermes Trismegisto 65). De manera que el alma humana tiene una parte divina, aunque su parte física es susceptible al deseo y la pasión; "cuando ésta entra en un cuerpo mortal y encuentra allí estos elementos irracionales, por su presencia se convierte en un alma humana" (5). Es por eso que en el hermetismo, el iniciado debe purificarse intelectualmente, antes de aspirar a la perfección. Su deber es "dar a la razón la dirección del alma", utilizando su conocimiento para elevarse hasta el ámbito de lo divino (156).

Aquí encontramos un importante paralelismo con la filosofía hegeliana. Las divisiones de la filosofía de Hegel siguen un patrón que es típico de muchas formas de la filosofía mística y hermética. Estas representan la etapa inicial de "purificación" para elevar la mente por encima del nivel de lo sensorial y lo mundano, como una preparación para la recepción de la sabiduría (Magee 4). La filosofía del espíritu representa en el sistema hegeliano una etapa inicial de purificación antes de recibir la doctrina del

habitar en ella. Y al punto que lo quiso se realizó, y vino a habitar la forma irracional. Y la naturaleza a su vez acogiendo a su amado se entrelazó entera con él y copularon juntos, porque eran amantes. Por eso es que, a diferencia de todos los demás seres vivos de la tierra, sólo el Hombre es doble: mortal por el cuerpo, inmortal por el Hombre esencial. Por consiguiente, a pesar de ser inmortal y poseedor de plenos poderes sobre todas las cosas, está sujeto a la muerte y sometido al Destino. Siendo superior a la estructura se volvió esclavo dentro de la estructura. (Los libros de Hermes Trismegisto 12-15) 
conocimiento absoluto. Dice el filósofo alemán en su dialéctica que las contradicciones en el corazón-centro del espíritu son el motor racional para el cambio histórico. Como ya hemos señalado, esto lo lleva a concluir que la historia es el desarrollo continuo de la "idea absoluta" por medio de un proceso dialéctico. En la conciencia de esta unidad dialéctica, de esta unidad viviente, de las diferencias, se escinde la conciencia de sí misma, y, por consecuencia, tiene en ella misma su diferencia, en donde se inician en otros términos el conocimiento de que constituye la verdad del ser natural, la conciencia y el conocimiento del yo (La filosofía del espíritu 316). Es decir, las contradicciones en el espíritu universal pueden entenderse como dos caras de una misma discusión (argumento): tesis y antítesis que se resuelven en una síntesis de ambos. Este proceso continúa hasta que todas las contradicciones del espíritu se resuelven entre sí. En este punto final de la historia, Hegel propone que el espíritu ya ha adquirido completo conocimiento de sí.

En Póstumo el transmigrado, el espíritu no ha encontrado la paz o quietud que se espera luego de la muerte física. Es obvio que no se ha completado su proceso de purificación. En otras palabras, no se ha llevado a cabo el proceso dialéctico que le llevará a la integración con la divinidad. Sin embargo, "es precisamente, desde el desgarramiento que Póstumo reflexiona sobre el concepto de totalidad al que aspira" (Román-Eyxarch 125). Su sed de venganza es tal, que pide a las autoridades celestiales que 
le permitan ingresar en el cuerpo de Sisebuto para así regresar al mundo físico.

Póstumo no solo solicita regresar a la vida, sino que pretende hacerlo recordando todo detalle de su existencia pasada. El Ángel Custodio le advierte que "Dios, en su infinita sabiduría" ha decidido que todas las almas "beban las aguas del Leteo" para que no reencarnen arrastrando los recuerdos anteriores que solo les representarían un obstáculo en su proceso de purificación (Tapia, Póstumo el transmigrado 610). Pero Póstumo, sin importarle transgredir las leyes divinas insiste en que: "Llevaría, no una vida, sino ciento, a cuestas con tal de dar en cara con mi presencia a aquellos miserables. Después consiento en morir y olvidarlo todo" (611). Así pues, Póstumo y Sisebuto, dos polos opuestos se convierten en uno solo, creando un ente habitado por dos voluntades. Ello se ilustra muy jocosamente en múltiples ocasiones cuando "Póstumo mantiene una pugna entre su espíritu y el cuerpo de Sisebuto debido a los pensamientos y deseos de uno y las respuestas físicas del otro" (Martell Morales 191). Comienza entonces una tortuosa jornada hacia el aprendizaje y la purgación espiritual, y vemos cómo se manifiesta la ya mencionada guerra cómica 'tipo 'slapstick' entre Póstumo y Sisebuto" (Aponte Alsina 49). El alma de Póstumo no logra acostumbrarse a habitar el cuerpo de su rival, y: "en una de sus imprecaciones maldijo Póstumo a Sisebuto, y al lanzar la maldición, sintió que se le clavaban como alfileres por todo el cuerpo, haciéndole dar un jay! desgarrador" (Tapia 610). 
En otra ocasión pasa frente a un espejo, y al ver la imagen de su enemigo se da un par de cachetazos que le hacen gritar de dolor (686).

Como ya hemos señalado, en el hermetismo, los opuestos son los extremos de una misma cosa. Las enseñanzas herméticas sostienen que la diferencia entre cosas aparentemente opuestas es meramente una cuestión de grado. Se propone además que los pares de opuestos pueden ser reconciliados, y que tesis y antítesis son idénticas en naturaleza, aunque diferentes en grado. La reconciliación universal de los opuestos puede efectuarse mediante un proceso de alquimia mental. Por ejemplo, el amor y el odio, dos estados mentales en apariencia completamente distintos, se entrelazan hasta tal punto que muchas veces somos incapaces de afirmar si una cosa nos causa placer o disgusto. Es más, asevera este principio que es posible cambiar o transmutar las vibraciones de odio por vibraciones de amor en la propia mente y en la mente de los demás (El kybalión 13-15).

Entonces, si el "bien" y el "mal" no son sino los polos de una misma cosa, el hermetismo provee una herramienta, una alquimia para transmutar el mal en bien aplicando inteligentemente el principio de polaridad. Sin embargo, en el Transmigrado vemos cómo Póstumo, al querer tomar la justicia en sus manos y pagar un mal con otro mal, no logra reconciliar los polos opuestos y tiene que enfrentarse a las consecuencias de sus actos; en otras palabras, se aleja cada vez más de la obtención de la armonía unificadora y redentora como prescribe el principio de polaridad. Tapia acusa la terquedad de Póstumo al observar que: 
Condenado a vivir en el cuerpo de su enemigo, estaba en guerra consigo propio, pues ya aquel cuerpo era suyo... lo que debe extrañarse es que él, que [se] la echaba de filósofo a la fuerza en muchas ocasiones, no se hubiese convencido de que aquella guerra con su cuerpo era inútil martirio resignándose a adoptarle por amigo. De este modo, y reconciliado su espíritu rebelde con la carne que había servido a otro ser, se establecería al cabo una armonía que no pudo ser preestablecida. (668)

Aponte Alsina opina que debido a que Póstumo se niega a beber de las aguas del Leteo y así olvidar su vida pasada, se ocasiona un "desdoblamiento". Su negación va en contra de las leyes de la Naturaleza por lo que no encarna "ingenuamente", sino que "dos entidades coexisten en el mismo cuerpo". (46). En este caso se produce una "dualidad mala" que causa desarmonía y desintegración. ${ }^{43}$ En este conflicto entre el bien y el mal, o si se quiere, entre el polo positivo y el polo negativo, Hegel sugiere que el sujeto debe "particularizarse", es decir, individualizar o distinguir su existencia del concepto de libertad para que esa libertad pueda manifestarse, y tal existencia de su libertad hace que su interés y su bien vengan a ser, necesariamente, su objetivo y su deber (Filosofía del espíritu 433-434).

43 Contrario a la figura del andrógino, que representa la "dualidad buena" ya que representa un ente perfecto, en una etapa primaria, fundamental, sin restricciones (Aponte Alsina 49). 
Desde el comienzo de la narración, el propósito primordial de Póstumo es castigar a Elisa, a la que llama "una ingrata", y a Sisebuto, "un falso amigo", quienes según su percepción se aprovecharon de su bondad. El Ángel Custodio intenta en vano hacerle entrar en razón diciéndole que en realidad la culpa había sido suya, que para cambiar la situación, es necesario cambiar su intención: "Debes, por lo tanto, persuadirte de que el mal estuvo en tu propio carácter y que si volvieras a nacer en idénticas circunstancias a lo pasado te sucedería lo propio" (610). En otras palabras, Póstumo ha fracasado en su empeño de recrear la totalidad de su antigua existencia. Al volver a la vida en un cuerpo ajeno, se la pasa pugnando con la materia y ni siquiera consigue su propósito inicial (la venganza), puesto que Elisa lo abandona, y el alma de Sisebuto, transmigrada en el cuerpo de Postumito para hacerle la vida imposible, se deleita en verlo morir. Vistos los resultados desde la perspectiva hermética, el alma de Póstumo no logra armonizar su dualidad. La polaridad es una "paradoja divina". Aquellos que tienen el conocimiento pero no se han "purificado", piensan que pueden desafiar las leyes del universo, y así solo obtienen la destrucción. Aquellos que sí han entendido el propósito de la adquisición de la sabiduría mediante la naturaleza del universo, "usan la ley contra las leyes; lo superior contra lo inferior; y por el arte de la alquimia transmutan lo que es indeseable en lo que es apreciable, y así triunfan" (El kybalión 44). Su segunda muerte demuestra la imposibilidad de unificar lo que ha sido tan violentamente fragmentado, con 
lo que el narrador cierra la historia del Transmigrado advirtiéndonos que:

“illusos e inexpertos los que resucitan por su gusto!" (733).

En la segunda parte de la obra, Póstumo el envirginiado, vuelve nuestro protagonista a reencarnar por la fuerza, esta vez en el cuerpo de la hermosa Virginia, porque "no era la índole de Póstumo... conformarse largo tiempo con la quietud de los limbos espirituales a donde fue a parar" (741). Su espíritu, siendo muy inquieto y voluntarioso, cuando desea algo no ceja en su intento hasta conseguirlo, por lo que logra convencer a su Ángel Custodio de que le permita regresar a la Tierra, ya que la quietud de los limbos le fastidia sobremanera. Es así cómo se le antoja invadir un bello cuerpo femenino donde habitaba el alma de la joven Virginia, lo cual consigue al expulsar violentamente a la ocupante de dicha morada.

Una vez Póstumo toma posesión de su flamante cuerpo, descubre que ha adquirido también el compromiso de casarse con el duque de la Verbena. Nuevamente enfrenta el espíritu errante el problema de su concomitancia con el cuerpo humano; no obstante, asume su nueva identidad a tal grado, que llega al matrimonio con su prometido. Pero conforme pasa el tiempo, y aunque su marido la tenía viviendo "en opulencia y sus antojos eran leyes", Póstumo-Virginia se aburre del papel de esposa abnegada que le corresponde desempeñar e incluso considera el suicidio como salida de esa asfixiante existencia (775). Su Custodio, sin embargo, logra que abandone tales planes aludiendo a la obligación que ahora tiene con su esencia femenina. Póstumo-Virginia, aprovechando una trasgresión matrimonial de 
su marido, lo abandona y parte junto a su amiga Matilde hasta la capital francesa. Allí se convierte en cantante, y acompañada de su nuevo pretendiente, el inglés Lord Berkley, viaja por Inglaterra y Estados Unidos, donde entra en contacto con las ideas feministas de la época. Luego regresa a España totalmente comprometida con su nueva causa, y se da a la tarea de luchar por esta hasta el punto de disfrazarse de hombre y combatir en la revolución de septiembre de 1868. Póstumo-Virginia muere a causa de heridas sufridas en el campo de batalla. La obra concluye con un epílogo en el que se cuenta su regreso al otro mundo, y cómo se le encierra en una mazmorra como castigo por su inquietud y rebeldía.

Veamos entonces de qué forma podemos realizar una lectura hermética a este aparentemente descabellado relato. Justo al comienzo de la historia del envirginiado, el narrador nos describe el estado de inquietud en que se encuentra el alma del protagonista luego de su segunda muerte, puesto que:

como la índole o carácter es como si dijéramos la fisonomía del espíritu, viniendo a ser próximamente lo que apellidamos idiosincrasia individual; claro es que esto, ni murió con la carne de los cuerpos que, por su desgracia sucesivamente tuvo ni logró dejársela en su sepultura. Por lo tanto, siendo su índole de suyo descontentadiza y novelesca; aún después de darle por escarmentado, como debía, no lo estaba ni con mucho. 
Bien pareciera que el hegeliano Tapia deliberadamente construye una criatura escindida que va tras la unidad final, mediante el conocimiento empírico que en esta vuelta al mundo tiene la oportunidad de alcanzar. Y aún más, el autor parece darnos una clave al refererirse al espíritu como poseedor de una fisonomía, lo que nos hace recordar la Filosofía del espíritu de Hegel, obra que hemos venido citando ampliamente.

Ahora recordemos que el objetivo último de la doctrina hermética, o si se quiere, la salvación del hermético, es llegar al conocimiento de Dios, y Dios, siendo y estando en todas las cosas, constituye la realidad total: "Porque no hay nada en el mundo entero que no sea Él; Él es lo que es y lo que no es, porque lo que es lo ha manifestado, y lo que no es lo contiene en sí mismo" (Los libros de Hermes Trismegisto 89). Dios "que es el único y el todo, posee la plena y entera fecundidad de ambos sexos", de esta manera la Naturalez, que es reflejo de la divinidad, hace que todas las cosas que nacen y se reproducen posean también, las cualidades intrínsecas de ambos sexos (Los libros de Hermes Trismegisto 163). Es este el precepto de generación o género, y se manifiesta en todo y enseña que los aspectos de lo masculino y lo femenino están presentes y activos en todas las fases de cada plano existencial (El kybalión 112). La función del principio masculino parece ser la de dirigir una cierta energía inherente hacia el principio femenino, iniciándose así la actividad creativa. Pero el principio femenino es el que realiza siempre el trabajo creativo, y esto es así en todos los planos. Cada principio es incapaz de energía operativa sin la asistencia del otro. En 
algunas de las formas de vida, los dos principios están combinados en un organismo. Por eso, todo en el mundo orgánico manifiesta ambos géneros por lo que siempre está presente el masculino en la forma femenina, y el femenino en la forma masculina (116).

En su Filosofía del espíritu, Hegel señala que la subjetividad del ente animal contiene una contradicción y el deseo de conservarse por la supresión de la contradicción; y esta conservación de sí mismo es lo que constituye el privilegio del animal y, en un grado aún más alto, el del espíritu. Para que la contradicción sea realmente conciliada, es preciso que el contrario con quien el animal está en relación, le sea idéntico. Esto es lo que tiene lugar en las relaciones de los sexos. En este sentido, los sexos no sienten cada uno en su contrario un ser exterior y extraño, sino que cada uno se siente a sí mismo en el otro, o si se quiere, cada uno siente el género común (100-01). De esta forma, todo lo creado participa en la esencia del creador, ya que, como hemos señalado, Dios posee la capacidad fecunda de ambos sexos. No obstante, esta aparente dualidad divina no es más que el principio mismo de la unidad total, y:

no deriva de nada más que de él mismo, porque todo deriva de él. Él es él mismo su principio, puesto que no hay otro. La unidad, que es el principio, contiene todos los números y no es contenida por ningún otro... Lo que puede crecer crece por la unidad, y sucumbe a su propia debilidad cuando no puede recibir a la unidad. (Los libros de Hermes Trismegisto 86) 
De manera que el universo se encuentra en constante cambio y fluctúa entre ciclos de creación, generación y regeneración, y ya que el iniciado hermético posee las herramientas necesarias para emular a su creador, es imprescindible que, mediante la recepción del nous, o don del poder mental, imite a Dios en su proceso creativo. Para Hegel, esto se explica en términos del "Conocimiento Absoluto" que lleva al "Espíritu Absoluto". Como habíamos señalado anteriormente, para el filósofo alemán, la filosofía, es decir, el adquirir sabiduría por amor a la propia sabiduría, no es su objetivo, pues:

La filosofía del espíritu no tiene... por objeto este pretendido conocimiento que busca en el hombre sus rasgos, sus pasiones, sus debilidades individuales, y que escruta, como suele decirse, los repliegues del corazón humano; conocimiento que, por una parte, no tiene más valor que el que supone el conocimiento general del hombre... y, por otra parte, sólo gira sobre los accidentes, sobre los productos insignificantes y pasajeros del ser espiritual, y no penetra en su sustancia, ni en su naturaleza íntima. (Filosofía del espíritu, 87)

De la misma manera, la hermética entiende que quienes "fueron bautizados en la Inteligencia", poseen la "gnosis" y se convierten en "los iniciados de la Inteligencia, los hombres perfectos" (Los libros de Hermes Trismegisto 84). Así vemos que lo expuesto en el Corpus hermético acerca de la verdadera o pura filosofía: "Adorar la divinidad con sencillez de pensamiento y alma, venerar sus obras, bendecir su voluntad que es la única plenitud del Bien, he 
aquí la única filosofía que no se encuentra viciada por la inútil curiosidad del espíritu" concuerda con la idea de un Hegel hermético presentada por Magee (Los libros de Hermes Trismegisto 157).

Apunta Magee que para obtener la salvación, el hermético debe encontrar la gnosis, es decir, debe vivir en el mundo y conocer todo cuanto pueda mediante esta experiencia. En cierta manera, al insistir en su deseo de volver a encarnar, Póstumo va en busca de ese conocimiento que le abriría las puertas de la sabiduría: "¡Custodio de mi alma!... iqué felicidad sería volver a la tierra en cuerpo tan hermoso!... Así podría comprobar y saber lo que pasa dentro del cuerpo de la mujer" (742). Mas no solo debe conocer la doctrina, "but have the real-life experience of the truth of the doctrine. One must be led up to illumination carefully; one must actually explore the blind alleys that promise illumination but do not deliver" (11). El alma de Póstumo necesita de esta experiencia para poder adelantar en su camino hacia la unión con la divinidad. Habiendo sido hombre en su antigua existencia, ahora completaría el ciclo de conocimiento esencial para su progreso. Si en la primera parte de la obra la polaridad de su existencia (Póstumo-Sisebuto) le permitió experimentar la vida en el cuerpo de su rival, ahora tenía la oportunidad de unir en un solo cuerpo la polaridad de lo masculino y lo femenino.

A continuación, el alma de Póstumo se apodera metafóricamente del cuerpo de Virginia mediante un acto de violenta intromisión. Al observar a la bella joven que camina junto a su madre por el paseo de la Castellana, el 
espíritu de aquel "púsose a caracolear en torno de la dama a guisa de moscón" (745), y desoyendo las advertencias del Custodio, se cuela en el cuerpo que tanto se le antoja:

Al sentir el espíritu de Virginia que se le colaba dentro del cuerpo un intruso tan osado, encogióse como guerrilleros que se repliegan y trató de buscar refugio en algún rincón por entre el laberinto de nervios, membranas, vasos, venas, arterias y músculos que se llama cuerpo humano. (749)

Se libra una batalla campal entre ambas ánimas que pone de manifiesto el concepto de dualidad que habrá de continuar a lo largo de la obra. SaldiviaBerlung observa que mediante la contradicción que entraña este acto de violación metafórica Tapia concede representación a la mujer mediante un "yo masculino" que ocupa su mente y su cuerpo (44). Por su parte, Aaron M.M. Suko ha visto que el mensaje posterior a favor de la igualdad femenina y la construcción social de género que surgen de la lectura de Póstumo el envirginado se complica a causa de la problemática expulsión física inicial (20). Paradójicamente, Póstumo termina abogando por los derechos de las mujeres después de invadir un cuerpo femenino. Por un lado, esa imagen violenta arroja sombras sobre los ideales feministas defendidos en el resto de la obra, ya que perpetua la idea de superioridad del macho. Por otro lado, este acto chocante inmediatamente al comienzo de la historia invita al lector a averiguar en qué terminará todo. Entonces, este acto de reencarnación forzada es el vehículo que utiliza Tapia para atraer a los lectores con el fin de 
difundir su crítica social. La contradicción entre el desalojo inicial y lo que sigue nunca se resuelve por completo, sin embargo, Póstumo decide sacar el máximo partido de su nueva situación.

Una lectura hermética nos sugiere aquí el principio de la generación mental, el cual asocia la llamada mente objetiva, mente consciente, mente voluntaria, mente activa con el precepto masculino, mientras que el precepto femenino de la mente corresponde a la mente subjetiva, mente subconsciente, mente involuntaria o mente pasiva (El kybalión 120). Conscientes del carácter controversial de este postulado, proponemos que se considere este análisis desde la visión biológica primaria que animaría estas milenarias propuestas herméticas. La propia Beauvoir reconoce una intrínseca diferenciación entre las funciones observables en la Naturaleza puesto que "en el nivel más alto de la escala animal, los dos sexos representan dos aspectos diversos de la vida de la especie" (36). No obstante, la diferencia no debe verse en términos de actividad y de pasividad, sino que, tal como se explica en El kybalión, la función del principio masculino parece ser el de dirigir "una cierta energía inherente" hacia el principio femenino, iniciando así a la actividad generadora. Mas es el principio femenino el que hace el trabajo creativo, y esto se manifiesta en todos los planos de la existencia. De hecho, en algunas formas de vida, los dos principios se encuentran integrados en un organismo: "Por eso, todo en el mundo orgánico manifiesta ambos géneros; siempre está presente el 
masculino en la forma femenina, y el femenino en la forma masculina" (114116).

El progreso espiritual también puede verse desde esta perspectiva; a partir del encuentro entre estas dos voluntades. De esta forma, los principios femenino y masculino están siempre activos en la Naturaleza. Sarah Wamester Bares ha visto en el texto de Tapia y Rivera una importancia que reside en una propuesta de la relación entre la identidad de género y la sexualidad radicalmente diferente de la que se manifiesta en los escritos de sus contemporáneos y nos invita a que antes de descartarla desde la perspectiva de nuestra época, la veamos como una idea extremadamente radical para el momento de su propuesta (200). La narración coloca el género dentro del cuerpo, no del alma; el alma "sin género" de Póstumo "recuerda" su cuerpo masculino pasado. En el texto de Tapia, todo el mundo, no solo la mujer, está ligado a su propia corporeidad, y el alma, la cual está sujeta a la reencarnación, se adapta a cualquier cuerpo en el que se le coloque luego de olvidar su vida anterior en "las aguas del río Leteo". Pero Tapia crea un personaje que desafía la caracterización de Póstumo y Virginia, es hombre y mujer, está muerto y está vivo, es homosexual y heterosexual --- todo al mismo tiempo --- como si estuviera sugiriendo que cada uno de nosotros es simultáneamente todas estas cosas (Wamester Bares 207). Póstumo en su nuevo cuerpo continúa resistiéndose al aprendizaje espiritual al que se le ha sometido, por lo que interviene su Custodio para recordarle que en esta vida era una mujer y que a pesar de 
que el sexo (género) es un "accidente de la materia", se deben "tener en cuenta sus condiciones... Al apoderarte de ese nuevo cuerpo, has contraído también los deberes que le eran propicios" (611).

Judith Butler atribuye al género la cualidad de performativo, o sea, que la identidad de género no es más que una cuestión de actuación ya que las identidades femeninas y masculinas se definen solo mediante la manera en que se comportan o actúan las personas (24-25). Al igual que para Beauvoir, para Butler no hay características esencialmente femeninas o masculinas, sino que se espera que los hombres y las mujeres se comporten de cierta manera, profundamente enraizada en la desigualdad histórica y promovida por quienes detentan el poder. En comparación con Beauvoir, Butler se muestra muy pesimista sobre las perspectivas de la libertad eventual de las cadenas de la opresión patriarcal, y explica que aunque es imposible borrar por completo las leyes por las que se rige las sociedad patriarcal, esta se puede satirizar, y así poner en marcha cierto sentido de progreso.

Es esta sátira social la que podemos advertir en Póstumo envirginiado de Tapia. Durante la ceremonia matrimonial de Virginia y el duque, esta comienza a sentir los efectos de su inusual retorno terrenal. Al advertir entre los invitados la presencia del joven Salazar, siente una intensa y perturbadora atracción que le lleva a preguntarse si “¿podría ser insensible a las emociones del cuerpo a que pertenece, en una palabra, a la organización física según hemos tratado de patentizar cuando hablamos de los hábitos y resabios corporales?" (766). Y pasados tan solo unos minutos Póstumo ve a 
la joven Matilde, condesa del Cierzo, y "parece que la vio con los ojos de hombre que había sido, y ¡chas! nuevo flechazo" (766).

La novela alude así a los tabúes sexuales de la sociedad cuando Póstumo-Virginia comienza a experimentar una serie de sentimientos directamente relacionados con la dualidad de su ser. La idea de serle infiel a su nuevo esposo la atormenta, y al consultarlo con el Custodio descubre que el gallardo mancebo que tantas cavilaciones le ocasiona es "nada menos que el espíritu de Elisa, la de Doble Anzuelo, engarzado en cuerpo masculino" (775). No pudiendo contener los avances amorosos del galante Salazar trata de huir buscando amistades "menos peligrosas que consolasen hasta cierto punto la soledad de su corazón" (770). De esta forma se acerca a Matilde, a quien "veía sin duda con ojos varoniles, razón suficiente a explicar tan acentuada simpatía. La amistad entrambas damas llegó a ser íntima” (789). Por tal motivo Matilde consulta con un sacerdote, quien le recomienda evitar el trato con aquella dama, y prevenir la tentación con la penitencia, la oración, el ayuno y los cilicios. Sin embargo, Matilde vuelve donde Virginia y le promete no separarse de ella si se flagelan mutuamente. Las escenas de flagelación entre ambas llegan a ser "sumamente eróticas y casi lésbicas" (Martell 191). Póstumo entonces comprende que a Matilde "aquel misterio de hombre y mujer le encantaba y enloquecía exaltando su maravillosidad" (836).

Suko plantea que las metáforas que aluden al doble y al conflicto entre lo interno y la apariencia externa están presentes desde el principio, y abren 
efectivamente el texto a múltiples lecturas. Abundan en toda la narración las escenas que involucran ocultas realidades internas en conflicto con las máscaras externas. Las descripciones narrativas y los diálogos muestran una y otra vez que detrás de lo aparente se esconde algo mucho más complicado. Más que una simple entidad con una trayectoria fija, PóstumoVirginia pone de manifiesto el conflicto y el compromiso entre el yo y el cuerpo, y entre el yo y la sociedad (18). Tapia sabía entonces "que creaba un 'organismo incomprensible', a la manera de un nuevo Barón de Frankenstein, que como el monstruo de Mary Shelley fuera portavoz de las ideas que el autor no se arriesgaba a expresar" (Aponte Alsina 51). En una emblemática escena, la duquesa de la Verbena, es decir Póstumo "envirginiado", visita a la famosa modista Madame Choufleur, quien aprovecha la oportunidad para lisonjear la hermosura de su importante clienta; el narrador tapiano comienza a discurrir sobre lo que llama "la gracia del cuerpo", la cual se manifiesta según el sexo que el alma habita. No obstante, para el proceso de creación --el cual el hermetismo denominaría como principio de género--- es necesario que el ser humano utilice sus inmanentes propiedades bisexuales, ya que para:

producir en el arte y en las letras dignamente necesita la complexión híbrida o sea la de los dos sexos. Es decir que el buen artista, y acaso también el filósofo, tienen que tener de hombre y mujer para ser fecundos, verdaderos y completos en sus concepciones, puesto que examinadas éstas, cuando son 
cabales, siempre revelan elementos propios de los dos sexos.

Esta reflexión nos devuelve a la tesis de Magee, en la que propone que la filosofía de Hegel es enciclopédica y, como se ha observado, intenta acabar con la filosofía misma, atrapando la realidad total en un lenguaje-discurso completo y circular. Lo que promete el sistema de Hegel es una experiencia transformada del mundo, en la que vemos las cosas familiares bajo una nueva luz. La ciencia, la poesía, el arte, la religión, el estado, son vistos como expresiones o formas de realización del Absoluto. Las cosas ordinarias adquieren de repente un nuevo significado, de esta manera Hegel intenta cerrar la brecha en entre el pensamiento y la sensación, ofreciéndonos una nueva interpretación del proceso que entraña la experiencia (Magee 97). Para Hegel esta unidad de la conciencia general y la conciencia propia: contiene al principio los individuos, como apareciendo los unos en los otros. Pero en esta identidad su diferencia es la diferenciabilidad de hecho indeterminada, o mejor dicho, una diferencia, que mo es allí una. Por consecuencia, su verdad es la universalidad y la objetividad, en y por sí de la conciencia de sí, la razón. (Hegel, La filosofía del espíritu 335)

Paralelamente, con su segunda transmigración, Póstumo comprende lo que implica ser mujer, lo que es estar "sometida" a la voluntad y a las órdenes del hombre, y lo que se siente al carecer de verdaderos derechos 
sociales, políticos y morales. ${ }^{44}$ Esto le lleva a declarar que para algo ha de servir su capricho de meterse "en este cuerpo femenino sin dejar de tener alma resabiada de varón. Ser mujer y sentir como hombre, ¿puede haber mejor situación para ver y sentir la verdad y la justicia? El verdugo sintiéndose con el corazón de la víctima y corriendo con su suerte, ¿podría descargar el hacha homicida?" (864). Por tanto, el don de la palabra también puede llevar a la iluminación espiritual, es decir, a la armonía o unidad que persigue el alma de Póstumo, pues tiene que ver con la realidad total en un lenguaje completo y enciclopédico. Como hemos ya planteado, la generación se manifiesta en todos los planos: el físico, el mental y el espiritual. Póstumo se reconcilia bastante pronto con el hecho de que ahora posee cuerpo de mujer, pero no acepta la necesidad de acomodarse a las convenciones sociales que deben seguir quienes poseen tales cuerpos cuando advierte que: "me parece una injusticia con el nombre de lo contrario, porque lo justo

${ }^{44}$ Según Platón, el alma es inmortal, eterna, no ha nacido, no puede conocerse mediante los sentidos; el cuerpo, a su vez, es material, impuro, sensible, está lleno de pasiones, apetitos, deseos, instintos. Platón tiene una concepción dualista del hombre, al igual que del mundo. Del mismo modo que el mundo de las ideas tiene prioridad sobre el mundo sensible, el alma la tiene sobre el cuerpo. En su Fedón, Platón manifiesta que la inmortalidad del alma implica la preexistencia. Explica, además, que la unión con el cuerpo es transitoria, antinatural, accidental, ya que el lugar propio del alma es el mundo de las ideas, y su actividad propia es la contemplación de las mismas. Las almas salen de las manos del demiurgo, y todas son iguales, eternas, atemporales. Cada una cae en un cuerpo, por accidente. Esa es la primera encarnación. Después el alma va peregrinando, eligiendo su destino, de cuerpo en cuerpo. En la encarnación de un nuevo cuerpo, se elige un nuevo género de vida. Lo importante es que la razón domine las pasiones, los sentimientos y los deseos, y así pueda en sucesivas reencarnaciones llegar a la contemplación de la verdad. 
no es hombre ni mujer, y las leyes y las costumbres si han de ser justas, deben estar basadas en el alma, que es la esencia, y no en el sexo del cuerpo que es puro accidente" (746). Nuestro(a) protagonista "cuestiona abiertamente las características que tradicionalmente se atribuyen a cada género y... favorece el surgimiento de un nuevo fecundo híbrido bisexual" (Bernabé Riefkohl 245-247)

En síntesis, Póstumo el envirginiado es la representación de la necesidad intrínseca de reconciliación del ente humano con sus dos naturalezas: la masculina y la femenina. Es el campo de batalla en el que el arma principal es su dualidad. Resulta revelador el hecho de que la parte masculina de Póstumo no intente nunca imponerse, "por el contrario, aprovecha su sensibilidad masculina para notar y sentir, ahora en cuerpo de mujer, las injusticias... para con ésta" (Castro Pérez 142). ¿En qué pueden fundar los hombres su superioridad sobre las mujeres? El Envirginiado llega a la conclusión de que esa supuesta superioridad quedará aniquilada puesto que el hombre, reconociendo su unidad precisamente en la dualidad genérica que le es intrínseca "se tornará más reflexivo, porque no convirtiéndose en tirano de las mujeres no vendrá a ser su esclavo y pagará menos tributos al mundo de muñecas que ha creado para ellas y que como puñal de dos filos le alcanza y hiere también" (860). Solo así se logrará la integración de las cualidades supuestamente opuestas que necesariamente llevan a engendrar una nueva criatura, la que a su vez continuará engendrando, creando y recreando. Veremos en el próximo capítulo cómo los principios de polaridad y 
generación están íntimamente relacionados con otro principio hermético muy importante: el mentalismo. 


\section{CAPÍTULO V}

La sombra: Sustancia mental y causalidad

And to every action there is always an equal and opposite or contrary, reaction. Isacc Newton

El presente solo se forma del pasado, y lo que se encuentra en el efecto estaba ya en la causa.

Henri Bergson

Human knowledge and human power meet in one; for where the cause is not known the effect cannot be produced. Nature to be commanded must be obeyed; and that which in contemplation is as the cause is in operation as the rule.

Francis Bacon

La sombra, primera novela escrita por Benito Pérez Galdós, gira en torno a la conversación entre sus dos personajes principales que, a manera de choque entre fuerzas opuestas o en conflicto, que según Bahktin coexisten en todo código verbal, puesto que pueden identificarse con facilidad dos corrientes lingüísticamente contradictorias. ${ }^{45}$ La relación que se desarrolla entre estos personajes "es particularmente útil como introducción a un estudio de lo que se ha llamado... 'locura narrativa', ya que dramatiza claramente la tensión... entre lo que el texto dice y lo que el texto hace" (O'Byrne Curtis 225).

La historia cuenta el desarrollo de la supuesta locura de Anselmo y sus nefastas consecuencias, a quien todos apodan "doctor", dada su afición

\footnotetext{
${ }^{45}$ Recordemos que Bahktin plantea que en la narrativa se da un conflicto entre diversos tipos de discurso (el de los personajes, el del narrador, y el del propio autor).
} 
por la lectura de libros de ciencia y experimentos químicos. ${ }^{46}$ Los problemas comienzan a raíz de su matrimonio con la hermosa Elena. Cuenta Anselmo que en su casa había grandes riquezas y espectaculares colecciones de arte. Mas entre todas aquellas esplendorosas pinturas sobresalía la que representaba a Paris y Elena en una gruta de la isla de Cranaé. En una ocasión la joven esposa comenta sobre la belleza de la figura de Paris, y desde entonces el llamado doctor no puede sacarse aquella imagen de la mente. Un buen día entra Anselmo al salón donde se encontraba el cuadro, y nota con espanto que la figura de Paris ya no estaba en el lienzo. Inmediatamente comienza a sentir unos celos enfermizos, ya que sospecha que su esposa le es infiel. Desde entonces comienza a ver a Paris por todas partes. Al principio era una sombra sólo visible al doctor Anselmo, pero luego se le manifiesta en la forma de un galante y refinado caballero de la época llamado Alejandro. Las acusaciones y el comportamiento irracional de Anselmo llegan a tal punto que provocan la enfermedad y muerte de su atormentada esposa. La novela concluye con el análisis del narrador galdosiano acerca de los acontecimientos que acaba de escuchar de labios

\footnotetext{
${ }^{46}$ La sombra está estructurada a manera de conversación entre el protagonista con un personaje sin nombre que sirve de narrador, y que podríamos tomar como una especie de locum tenens del propio Galdós (Austin 1) Es un intermediario o más bien representante del lector, que escucha, comenta y tira de la lengua del atormentado doctor. Germán Gullón plantea que el hecho de que la primera publicación de esta historia haya aparecido en forma de novela por entregas, podría explicar la constante intervención del narrador, pues el novelista, si quería mantener la atención del público, necesitaba refrescar la memoria de sus lectores con cada nuevo capítulo. Por otro lado, los autores estaban obligados a seguir unas reglas fijas; "cada capítulo debía concluir con una interrogación, con una exaltación del interés que incitase al lector a buscar la entrega siguiente" (351-52).
} 
del propio Anselmo, y así va colocándolos en el orden lógico en que según este debieron haber ocurrido. ${ }^{47}$

La historia se presenta a manera de conversación entre el personaje principal y un narrador del que ni siquiera sabemos el nombre. Tampoco sabemos las razones que lo llevan a visitar al "doctor" Anselmo. Germán Gullón ha señalado que La sombra "está estructurada sobre el cruce de imaginación y fantasía" (351). El estudioso de la obra galdosiana ha visto dos novelas en una, siendo la primera donde se nos cuenta sobre la enfermedad mental del protagonista; la segunda, superpuesta a la primera, plantea un enigma. El lector se ve obligado a confiar en el relato del narrador, quien impone su juicio a manera de diagnóstico cuando declara que: "es indudable que ese caballero no es otra cosa que la personificación de una idea" que Anselmo "tenía encajada en el cerebro" (Pérez Galdós 64).

La crítica ha concordado en interpretar la obra cual si se tratara de un estudio sobre la locura del personaje principal, y no es de extrañar, ya que Anselmo se refiere explícitamente a su condición mental. Rodolfo Cardona, en su conocido prólogo a La sombra, explica que hay que tomar en cuenta el

${ }^{47}$ Como ya ha observado la crítica, en la historia se revelan desde el principio las consecuencias de los sucesos que se nos contarán, pero los detalles se nos ofrecen por etapas. Anselmo comienza revelando el final de la historia, y con mucha reflexión, atención y cuidado va desenmarañando los motivos y los resultados de sus actos en tres capítulos: "El dr. Anselmo", "La obsesión" y "Alejandro". Francisco Ynduraín observa que los personajes parecen estar representando una obra teatral, por la manera en que se llevan a cabo sus conversaciones, sus entradas y sus salidas. Las circunstancias se desarrollan en el Madrid de la época, para cuya ubicación se nos refiere al Paseo del Prado y al de la Castellana, mientras que la relación de amistad-enemistad entre Anselmo y Alejandro marca el transcurso de los acontecimientos. Es decir, que se nos ofrece un "trasfondo ambiental" y "un tiempo implícito" (281). 
hecho de que Galdós, a diferencia del novelista del siglo XX, no tenía a su disposición los grandes descubrimientos psicológicos de la época freudiana. La naturaleza y las causas de la enfermedad mental eran, en su mayoría, un misterio, pero el interés de Galdós en explorar las fuerzas que rigen el comportamiento humano y las extrañas formas que asumen estas fuerzas lo llevan desde el principio de su carrera como novelista a jugar con lo "real" y lo "fantástico". De este modo llega a retratar, de manera intuitiva, varios "casos" en los que se muestra algo muy parecido a un detallado proceso psicoanalítico (Cardona xviii-xix).

En su estudio sobre las enfermedades nerviosas en algunos personajes galdosianos, María del Carmen Rodríguez Acosta señala que al parecer Anselmo sufre de "irritación" cerebral, pues aunque no se diga explícitamente, los síntomas de este se asemejan a los descritos en folletos pseudocientíficos de la época, como La enfermedad de los místicos, de Víctor Melchor y Farre, y Mimismo y neurosis imitante, de José Armangué y Tusset (305). Por otra parte, Carlos Clavería habla de las "alucinaciones hipnagógicas" del protagonista y "sobre la veta fantástica en la obra de Galdós" (35), y José Montesinos ve en novela "las posibilidades dramáticas de un conflicto entre la intimidad del personaje y ese espíritu social que lo rodea como un vaho denso y asfixiante, y lo tortura y alucina" (49). El propio Anselmo confiesa su mal sin vacilación al declarar que desde niño padece lo que llama "los estragos de mi imaginación" (Pérez Galdós, La sombra 22). 
Es justo decir que con frecuencia las historias fantásticas que cuenta Galdós son atribuidas a la mente febril de los locos, una técnica que añade perspectiva a la fantasía al sembrar la duda de su autenticidad. El lector bien puede hacer caso omiso de lo fantástico y considerarlo como los desvaríos de un loco, o aceptar el hecho como parte de una extraña realidad. En este sentido, la deuda de Galdós con Cervantes se hace patente (Schulman 17). ${ }^{48}$ Por consiguiente, se nos requiere aceptar que la sombra que persigue al protagonista no es más que una ilusión causada por su alterada condición mental: "una imagen falsa que se reproduce en la mente sin que exista realmente el objeto del estado patológico en Anselmo" (Pérez Galdós 27678). Galdós nos presenta a un hombre en un total estado de desconcierto, y en el que se descubre toda clase de "locas imágenes, mezcladas de discretos juicios, tanta necedad unida a grandes concepciones, que parecen fruto del más sano y cultivado entendimiento" (Pérez Galdós, La sombra 14). Entonces, ya confirmada la locura del protagonista, el asunto sería establecer, como señala Germán Gullón, "el por qué de ese imaginar incontenible y morboso" (355).

Ahora bien, visto desde la perspectiva hermética, Anselmo es una especie de creador, puesto que la actividad mental para los herméticos, al igual que para Hegel, no es sólo un proceso intelectual, sino un cambio de vida. De esta manera, el hermetismo es una "gnosis" positiva; saberlo todo, de alguna manera es tener control sobre todo (Magee 11). En La sombra

\footnotetext{
${ }^{48}$ Hasta el nombre del protagonista, Anselmo, es el mismo del marido en El curioso impertinente (Ynduraín 281).
} 
advertimos este proceso, aunque en vez de lograr el conocimiento propio, nuestro protagonista no tiene control de sus actividades mentales, y cae en una vorágine de pensamientos desordenados que no dejan de atormentarle. La mente de Anselmo es el terreno fértil en el que nace la obsesión que causa su ruina, por tanto, si analizamos la historia partiendo de la premisa hermética del mentalismo, tendremos una nueva interpretación de los hechos relatados.

En el capítulo anterior hablamos del principio de la polaridad, que establece que todo tiene dos polos que no son más que los opuestos de una misma cosa. La polaridad propicia lo que se conoce como "alquimia mental", una forma de mentalismo practicada por los antiguos maestros herméticos. El mentalismo establece que la naturaleza del universo es mental, y de esta forma explica todos los fenómenos mentales y psíquicos que, de otra manera desafían la comprensión científica. Este precepto se encuentra en el "Todo" (es decir, todo lo que existe en todas las manifestaciones y apariencias externas de lo que conocemos como universo), la vida, la materia, la energía, todo lo que es evidente a nuestros sentidos, todo se encuentra subordinado al dominio de la mente (El kybalión 9-10). En el caso de nuestro protagonista, el poder de la mente se ve claramente plasmado. Anselmo, haciendo uso de su alborotada mente crea un universo poblado con personajes y circunstancias que, en su dimensión vital, aparecen investidos de un vívido realismo. Anselmo parece estar constantemente inmerso en un monólogo interno, o más bien en una conversación con "interlocutores invisibles". De 
modo que, ya sean producto de la locura o de alguna actividad paranormal, las misteriosas apariciones que experimenta Anselmo, lo cierto es que todo se reduce a un producto mental.

Joaquín Casalduero advierte que el público de la época no prestó mucha importancia a esta historia del novato Galdós, no obstante, "el que conozca toda la creación galdosiana verá confirmada la necesidad de algunos de los motivos que han de reaparecer en la producción del escritor" (1). En su análisis sobre el rol del autor en La sombra, Karen Austin va más allá y plantea que la primera incursión de Galdós en la novelística demuestra un interés claro e innegable por lo sobrenatural (1).

A la pregunta del narrador acerca de la causa que lo lleva a dedicarse a la química, Anselmo contesta: "para atar la loca... para contenerla y obligarla a que no me martirice más" (Pérez Galdós 17). Necesita estar siempre ocupado en algo para no pensar: "Pero aquí no hay nada más que un pasatiempo: Que nadie espere de esto ningún adelanto científico" (20). Galdós, citando la conocida frase popularizada por Santa Teresa de Jesús, alude a "la loca", es decir, a la imaginación, a la elucubración, a ese flujo de pensamientos descontrolados que puede llevar a la suspensión del juicio o del uso de la razón. ${ }^{49}$ De hecho, el propio Anselmo confiesa no encontrar a nadie que se le asemeje: "únicamente puedo llamar prójimos a los místicos

\footnotetext{
49 "Quizá, más que el entendimiento, la imaginación, á [sic] la que, por ese motivo, llamaba oportunísimamente Fr. Luis de Granada, la loca de la casa" (De Jesús, Santa Teresa 80).
} 
españoles, que han vivido una vida ideal completa, paralela a su vida efectiva. Estos tenían una obsesión, un otro yo metido en la cabeza" (22-23). Curiosamente, el doctor Anselmo se dedica a la química, ciencia que estudia la estructura, propiedades y transformaciones de la materia a partir de su composición atómica, y que tiene sus orígenes en la alquimia, una actividad mágica y misteriosa, propia de iniciados. ${ }^{50}$ Los alquimistas consideraban sus doctrinas esotéricas como un deber sagrado que debía mantenerse oculto de aquellos que solo buscaban obtener riquezas, ya fuera engañando a ricos mecenas o intentando descubrir el secreto de la transmutación. Los adeptos basaban su práctica en gran medida en una serie de trece preceptos contenidos en la llamada Tabla de Esmeralda.

El hermetismo también nos habla de la alquimia, pero más bien de una alquimia mental. En El kybalión se dice que los antiguos poseían un conocimiento de astronomía trascendental llamado astrología; de química trascendental, Ilamado alquimia; de psicología trascendental, llamado psicología mística. Entre las muchas ramas secretas del conocimiento de los

\footnotetext{
${ }^{50}$ Las raíces de la química se remontan a los estudios de Platón, retomados por los árabes hacia el siglo VIII de nuestra era. Mientras Europa permanecía sumida en la oscuridad medieval, los árabes experimentaban el tratamiento de los metales en busca de la piedra filosofal, que les daría la clave del arte de combinar y descomponer sustancias para elaborar oro. El primer alquimista europeo fue el inglés Roger Bacon (1220-1292), que fue perseguido por la Iglesia católica y tuvo que exiliarse a París. Para su suerte, su protector y amigo, el cardenal Guy le Gros Foulques, llegó en 1265 al trono de Roma con el nombre de Clemente IV y le pidió un informe sobre sus experiencias en una carta secreta. El filósofo inglés dedicó dos años al informe, del que resultó su llamado Opus Majus (Obra mayor). Tanto él como Paracelso (1490-1541), los mayores alquimistas del renacimiento, son considerados hoy como los precursores de la ciencia experimental. Alquimia y química se derivan de la voz árabe kimiyá, que significa "piedra filosofal". Se ha sugerido que kimiyá, a su vez, proviene de kimi, que significa 'negro', palabra árabe con la que se designaba a Egipto.
} 
herméticos, se encuentra la conocida como transmutación mental.

Transmutación es un término usualmente empleado para designar el antiguo arte de la transmutación de los metales, particularmente de los metales bajos en oro. La palabra "transmutar" significa cambiar de una naturaleza, forma o sustancia a otra; transformar. Partiendo de esta definición, "transmutación mental" significa el arte de cambiar y transformar estados, formas y condiciones mentales. Así pues, la transmutación mental es el "arte de la química mental" o una forma de psicología mística práctica (El kybalión 2025).

En este punto conviene recordar el estudio de Sherman Eoff, "Galdós in Nineteenth-Century Perspective", en el que establece que tal vez la forma más fundamental de abordar el estudio de Galdós en relación con el pensamiento del siglo XIX, es a través de un examen de su reacción al racionalismo científico de su época. Debemos tener en cuenta que la posición que mantuvo entre un saludable respeto por la física y las ciencias sociales y la lealtad a los valores humanos que son independientes de las ciencias, no fue un compromiso entre dos puntos de vista contrarios, sino un esfuerzo de coordinación entre dos perspectivas posiblemente compatibles. La fuerza filosófica unificadora en este mundo aparentemente dualista es la idea de la evolución. La propia interpretación del novelista de diversos aspectos de las teorías evolutivas incuestionablemente subyace no sólo en su defensa del progreso material y social, sino que también representa, 
según Eoff, una poderosa influencia en su estudio del carácter humano y su visión del destino, ya que:

Within this evolutionary perspective, for example, the novelist's liking for paradox can advantageously be regarded from the viewpoint of Hegelian theory. Without affirming that Galdós actually studied the big names of European philosophical thought in his day, we can be fairly certain that he was conscious of them and in some way absorbed their ideas. So it is that Kant, Hegel, and even Schopenhauer become important points of reference. (6-7)

Entonces, aunque no pueda afirmarse que Galdós sea discípulo de la doctrina hegeliana, encuentra en Hegel un estímulo o dirección para sus inclinaciones metafísicas, sobre todo en la idea de la "conciencia del ser en sí mismo" y "el reconocimiento del ser en el otro". Galdós bebe en las fuentes de los movimientos intelectuales más importantes del siglo XIX, entre los que se encuentran: la ciencia positivista, las teorías de la evolución biológica y psicológica, la noción de que el hombre está formado por su medio ambiente, haciendo hincapié en la realidad de la mente, y la creencia de que el individuo desarrolla su potencial gracias a la relación que desarrolla con su comunidad, pero también mediante la evolución espiritual propuesta por Hegel (Eoff 150).

Paralelamente, Alexander Magee, para sustentar su teoría de que el pensamiento hegeliano es básicamente hermético, plantea que los textos 
alquímicos poseen un nivel literal y otro simbólico. Por un lado, describen el trabajo real de laboratorio que implica la manipulación física y la transformación de la materia. Por otro lado, parecen describir en forma alegórica, no la transmutación de la materia, sino la transmutación del espíritu del propio alquimista y de sus operaciones psíquicas o mágicas, un proceso que conduce a la salud psíquica e incluso a la integración física. La filosofía de Hegel puede interpretarse como la alquimia mediante la cual ocurre el proceso de separación de los componentes espirituales de los físicos. De esta forma se conserva el objetivo alquímico de perfeccionar la Naturaleza, pero esta obra se lleva a cabo en el alma del hombre, permitiendo a Dios realizarse y manifestarse mediante la actividad especulativa del hombre. Dios "se completa" o "actualiza" por medio de la actividad intelectual de su máxima creación. Así vemos cómo la filosofía no es sino la etapa final de la actualización del Espíritu Absoluto. Es una concepción circular de Dios y el cosmos en la que Dios "regresa" a sí mismo, convirtiéndose en Dios verdadero por medio del hombre (Magee 212-13).

Anselmo, desde su inestabilidad emocional, parece dialogar, no sólo con su interlocutor, sino también consigo mismo, y con su condición mental, la cual le hace cada vez más inseguro de los sentimientos de Elena hacia él. Esa pesadumbre da lugar en su mente desordenada a la aparición de Paris, un personaje demoníaco que es la encarnación de sus propios miedos. Paris como producto de la imaginación de Anselmo, y se podría argumentar así que no se trata de una entidad genuinamente paranormal. Mas es 
significativo el hecho de que una vez Anselmo "crea" a Paris, ya no tiene control de este. Austin señala cuán fácil resulta leer la obra como un estudio de la demencia del personaje principal, lo cual se justifica dadas las características que este mismo señala acerca de su persona. No obstante, esta historia representa la iniciación del autor en las técnicas novelísticas, "and some of these techniques, reflected in his choice and use of narrators, are particularly suited to the question of the validity of the abnormal and the nature of true reality" (1). No debemos olvidar tampoco que el propio Galdós afirma en su prólogo a la colección donde aparece La sombra que: "Se empeña uno a veces, por cansancio o por capricho, en apartar los ojos de las cosas visibles y reales" (Pérez Galdó 67). Más aún, las líneas que demarcan lo supuestamente real y lo imaginado comienzan a difuminarse cuando el narrador llega a confesar que el relato del doctor Anselmo le iba interesando aunque fuera por curiosidad, ya que había "una pequeña dosis de sentido en el fondo de todos aquellos desatinos" (71).

De primera instancia, según apunta Schulman, el lector no advierte la inestabilidad mental de Anselmo, y cree que lo fantástico es el motor de la acción (30). El propio Anselmo explica la génesis de su aflicción mediante una "dislocación encefálica acompañada de un cambio en los nervios ópticos" (Pérez Galdós 117). Además, menciona que su padre también fue perseguido por una sombra, planteando así la cuestión de una enfermedad hereditaria. Desde el comienzo de la historia, Anselmo se presenta como un hombre controlado por sus fantasías e incapaz de funcionar en el mundo 
real. No obstante, resulta particularmente irónico que Galdós intente convencer al lector de que Anselmo es, en efecto, perseguido por un fantasma o una sombra, para luego desmentir cualquier posibilidad de lo fantástico. Así, con su enigmática yuxtaposición de la fantasía y la realidad, Galdós crea una historia de ilusión e ironía (Schulman 30-31).

Si consideramos el elemento sobrenatural del argumento, vemos que se centra en la aparición de Paris como ente real ante los ojos del protagonista. En una especie de juego narrativo, el doctor Anselmo se convierte en una sombra de sus propios ardores mentales. Esta aparición podría justificarse como expresión de una reacción intensa de celos ante la admiración de su esposa por la figura de Paris en el lienzo del salón, pero todas estas posibles explicaciones de su demencia, contadas, paradójicamente, de una manera tan lúcida, nos llevan a dudar hasta qué punto es pura imaginación afiebrada, una verdadera persona o un verdadero fenómeno sobrenatural.

Cuenta Anselmo que un día entraba en su casa cuando creyó sentir la voz de un hombre en la habitación de Elena. Abrió la puerta precipitadamente, despertando el espanto de su esposa. Y luego de escudriñar la estancia con la vista se da cuenta de que no había nadie con Elena, no obstante, la figura de Paris ya no estaba en el lienzo. Es entonces que ve una sombra, y corre tras esta hasta un pozo en el que parece haber desaparecido tras arrojarle piedras y tierra. Más tarde, estando Anselmo en su habitación se le aparece Paris, su "rostro malicioso y agraciado, irónica su sonrisa, la mirada penetrante y viva", lo que lleva a Anselmo a concluir que 
se trataba de la figura del cuadro "hecha un ser real, un hombre del siglo XIX" (Pérez Galdós 48-49). Todos los miedos y temores de Anselmo se fortalecen cuando la "sombra" le reitera que él y Elena se aman y se han unido "por ley fatal" pues:

Yo soy lo que usted teme, lo que usted piensa. Esta idea fija que tiene usted en el entendimiento soy yo. Yo vivo en su conciencia, donde estoy tejiendo sin cesar una tela sin fin; vivo en su entendimiento, donde he encendido una llama que alimento sin tregua. (25)

Así pues, Paris ha entrado a casa de Anselmo porque este mismo le abrió la puerta. Paralelamente, vemos en el hermetismo que todo lo que llamamos "fenómenos psíquicos", "influencia mental", "ciencia mental", o "fenómenos del pensamiento", operan a lo largo de las mismas líneas generales, pues no hay sino un principio, no importa con qué nombre puedan ser llamados los fenómenos.

Anselmo mismo ha creado a Paris-Alejandro, está convencido de que existe, y hasta el propio ente, fantasma o idea le confronta:

¡Necio! -exclamó-, tú me has llamado. Tú me has dado la vida: yo soy tu obra. Te haré recordar, aunque la comparación sea desigual, la fábula antigua del nacimiento de Minerva. Pues bien, yo he salido de tu cerebro como salió aquella buena señora del cerebro de Júpiter: yo soy tu idea hecha hombre. Mas no creas por eso que no tengo existencia real: yo ando por 
ahí como tú, me conoce todo el mundo, soy un Fulano de Tal, como cualquiera. (121)

Puesto en términos herméticos podemos decir que si todo es mental, entonces el arte que capacita para transmutar condiciones mentales debe capacitar también para controlar las condiciones materiales, así como de las mentales. Es decir, si el universo es mental en su naturaleza, entonces la transmutación mental es el arte de cambiar las condiciones del universo mediante la fuerza de la mente. $Y$ es esto precisamente lo que hace Anselmo: cambia su universo, aunque no tiene idea de cómo lo ha hecho, por tanto, no puede calibrar los resultados de su mentalismo.

Tanto Hegel como el hermetismo se refieren al proceso de iniciación a través del cual la parte intuitiva del intelecto se capacita para ver la "razón" o inteligencia inherente al mundo. La iniciación hermética consta de dos partes, una dedicada al conocimiento propio, otra dedicada al conocimiento de Dios. Se puede demostrar fácilmente que ambos están íntimamente ligados. Para conocerse realmente a uno mismo, uno debe ser capaz de dar un discurso completo sobre las condiciones de su ser, y esto implica hablar de Dios y del cosmos. Uno no sólo debe saber doctrina, sino también tener la experiencia en la vida real de la verdad de esta doctrina (Magee 10-11). Sin embargo, en la novela vemos claramente cuando el narrador mismo se impacienta y desea ver cómo reacciona el protagonista al enfrentarse con la sombra, es decir, Anselmo da vueltas a la historia, pero no parece entender cómo 
ocurrieron los hechos, lo que levanta la sospecha de que todo sea producto de su imaginación.

La palabra imaginación, de hecho, se cuela constantemente en la obra de Galdós, y casi siempre en referencia directa a los personajes, muchos de los cuales se caracterizan precisamente por la exaltación imaginativa. La imaginación domina sus personalidades, dictándoles una forma determinada de vida. De un lado, están los entes ficticios a quienes se atribuye en el texto una imaginación que está matizada por una constante obsesión. Por otro lado, la imaginación puede ir más allá de la exaltación y la desmesura, siendo capaz de estimular que el ser elabore construcciones imaginativas de accidentes sustanciales que en ella ocurren (Gullón 35).

Para Hegel, la imaginación constituye una herramienta para lograr el objetivo del espíritu, que es la libertad y el conocimiento propio. Y para el espíritu el modo de lograr tal libertad es mediante el pensamiento. La imaginación, según Hegel, es una de las facultades del espíritu (entre las que se destacan la intuición, el recuerdo y el deseo, entre otras) es decir, es uno de los modos universales en que el espíritu actúa. Por tanto, la imaginación se encuentra entrelazada con el acto de pensar. Hegel clasifica la imaginación en dos sentidos. El primero se centra en su carácter "reproductivo", en el cual la inteligencia se vale de la fuente de reserva inconsciente formada por el contenido del mundo sensible. En la segunda forma de imaginación --la intuición de sí-- de la relación inmediata consigo 
mismo, tal como se forma en la imaginación reproductiva, deviene un ente o cosa (Hegel, Filosofía del espíritu 351).

Todo esto conlleva una alquimia mental, un proceso de transformación del alma que aspira a la perfección, y que consiste en sustituir con pensamientos positivos las creencias que obstaculizan el desarrollo. El poder mental del doctor Anselmo, por el contrario, lucha contra su naturaleza desordenada sin poder controlarla; de hecho, este se queja de tener lo que parece ser otro ser dentro de sí, "otro que me acompaña a todas partes y está siempre contando mil cosas que me tienen estremecido... Y lo peor es que esta fiebre no me consume" (Pérez Galdós, La sombra 22). Curiosamente, desde la perspectiva de Anselmo la fiebre le "vivifica" y "regenera" su naturaleza. De modo que, Anselmo reconoce que su imaginación no es la energía productiva de los seres intelectuales, poseedores de coordinación y coherencia mental, sino que es una fuerza frenética y constante que produce "sin cesar visiones y más visiones" (21). No debe perderse de vista que en la Edad Media, los alquimistas buscaban infructuosamente transformar los metales primarios en oro, sin embargo, para los iniciados, la alquimia era una alegoría del proceso de transformación mental y espiritual mediante el cual, como hemos señalado, se van sustituyendo los pensamientos negativos y obstaculizadores por pensamientos positivos. En el caso de Anselmo, en cambio, este intenta remover los obstáculos avivando sus pensamientos negativos y reaccionando violentamente. No es fortuito el hecho de que la madre de 
Elena le reclame y culpe de la enfermedad de su hija diciéndole: "Tú la has traído al estado en que se halla con tus violencias, con tus acometidas, con esos bruscos allanamientos de morada que has hecho en su cuarto, con el horror que le inspiraste, con la turbación moral que has producido en ella" (52). Tampoco es mera coincidencia que, a raíz de estos incidentes Anselmo intente infructuosamente matar a Paris-Alejandro. Tan sólo logra que aquel le confiese su inmortalidad, confirmándole así que contra él no hay nada que prevalezca.

Todo esto parece reafirmar los resultados de la alquimia que opera en la mente de nuestro protagonista. Karen-Claire Voss, quien ha explorado el tema de la alquimia como disciplina espiritual, sugiere que el término "alquimia espiritual" es una designación aún más precisa utilizada por los propios alquimistas. Esta transformación se entendía como una forma de iluminación, un medio de transmutación, un método para experimentar niveles de la realidad que no son normalmente accesibles, ya que existen más allá de la realidad cotidiana. La "alquimia espiritual", trabaja con sustancias físicas, pero de una manera muy particular, ya que incluye todas las características de la alquimia material, al tiempo que va más allá de este proceso, propiciando una experiencia de transmutación que resulta en un cambio ontológico (67). Bien pareciera por todo lo anterior, que Anselmo, sin proponérselo, hace uso de la alquimia mental para transformar su realidad, y como ya hemos señalado, no importa si la transforma a causa de una enfermedad mental o si en verdad ha creado un ente físico llamado Paris. El 
hecho es que la historia se desarrolla y desemboca en unos acontecimientos que encajan perfectamente con otro principio hermético: el de causa y efecto.

Por todo lo expuesto, si la existencia de Alejandro resulta ser o no una mera proyección de la mente enferma de Anselmo, es decir, el efecto inevitable de los celos enfermizos de este, lo cierto es que "la sombra" es el agente catalizador de unos sucesos nefastos. La obsesión del llamado doctor es la causa de la muerte de su esposa Elena. Entonces, las cosas no ocurren por casualidad, sino que, según el principio de causa y efecto nada sucede por causa de la suerte o el azar, pues empleamos este término sólo para referirnos a causas desconocidas por nosotros. Todo en el universo tiene una causa específica, y la magnitud del efecto es equivalente a la importancia de la causa que lo generó.

Retomando llos preceptos de la filosofía hermética nos encontramos en el Corpus hermético una serie de fragmentos llamados las Églogas morales de Estobeo, en los que se establece que: "En nosotros está la elección, de nosotros depende escoger lo mejor o lo peor por nuestra propia voluntad. La elección del mal nos acerca a la naturaleza corporal y nos somete al destino" (Los libros de Hermes Trismegisto 251). De lo anterior se desprende entonces que los celos, las dudas, las acusaciones de infidelidad, los constantes sobresaltos y discusiones de Anselmo hacen de la vida de su esposa un infierno, y son la causa de la muerte de esta. Vale la pena recordar que Elena sufre un empeoramiento de salud repentino, y su madre no cesaba de acusar a Anselmo por lo sucedido increpándole: 
¿Cuál otra puede ser la causa de este funesto ataque, sino las extravagancias de Anselmo, que la lleva al sepulcro con las mortificaciones incesantes a que la tiene sujeta? Es imposible que una naturaleza delicada resista a esa lenta inquisición" (118-19).

Su suegro también lo confronta y le alega que "todos en la casa dicen que estás loco" y que con su consentimiento un amigo suyo, un tal Alejandro, entra y sale de la casa haciendo que personas inescrupulosas pongan en duda la honra de su hija (94-97). Incluso Paris-Alejandro vuelve a recriminarle diciendo: "Tú tienes la culpa... tú que me has Ilamado, que me has traído, que me evocaste con la fuerza de tu entendimiento y de tu fantasía" (81). Todo esto nos lleva a afirmar que la obsesión de Anselmo crea una realidad que no tiene vuelta de hoja. El propio Paris-Alejandro confirma que aunque quisiera marcharse no tiene el poder de hacerlo mientras Anselmo continúe con sus "ideas y sensaciones".

No obstante, una vez Elena muere, Paris desaparece y Anselmo confiesa que se siente libre. Esto concuerda con la hipótesis de la idea fija y la obsesión enfermiza, pero encaja también con el postulado de que Paris es un personaje dependiente de la actividad mental de Anselmo. El narrador galdosiano intenta entonces conectar los hechos de manera cronológica, ofreciendo su propia versión al doctor Anselmo:

Preocupose usted con aquel hombre, tuvo celos, pensó en eso noche y día, y ese pensamiento fue dominándole hasta el punto 
de ocupar todo su espíritu: la continua fijeza del pensamiento en una idea dio gran vuelo a su fantasía, debilitáronse sus fuerzas corporales con el predominio absoluto del espíritu, y de aquí ese estado morboso que lo mortificó tanto. (120)

Si se tienen en cuenta estos sucesos a la luz de la doctrina hermética de la relación "circular" entre Dios y la creación, encontramos que también guardan una estrecha relación con el pensamiento hegeliano. No sólo el hombre desea conocer a Dios, pero Dios también desea ser conocido por la criatura más gloriosa de su creación (Magee 9). Al comprender este principio entendemos que todo lo que sucede, favorable o desfavorable, tiene que ver con causas que hemos puesto en movimiento en algún momento, de forma consciente o inconsciente, y que no tiene sentido culpar a Dios, a los demás o a la suerte, pues somos nosotros quienes labramos nuestra propia vida. No importa que no recordemos el instante preciso en que todo comenzó, o que tal vez se nos haya olvidado lo que hicimos en muchos momentos de nuestra existencia, el principio de causa y efecto siempre se encuentra actuando y se nos presenta de manera inevitable. Entonces, el buen uso del mentalismo nos permite encontrar la solución a muchos de los problemas en la vida, al asumir la responsabilidad de generar causas favorables de forma consciente, algo que nuestro protagonista es incapaz de realizar.

Llegado a este punto, hemos visto cómo el principio de causa y efecto se manifiesta sobre cada plano de la existencia, teniendo todo efecto su causa y teniendo toda causa su efecto. Todo esto parece confirmar este 
axioma hermético que, de acuerdo a la filosofía hermética, incorpora uno de los grandes principios de los fenómenos universales. Podemos concluir entonces que, conforme a cómo utilicemos los principios de metalismo y de causa y efecto, veremos la manifestación (positiva o negativa) de la naturaleza universal. Al conocerlo todo, se tiene control de todo, y utilizando el poder mental el individuo se capacita para comprender las leyes que rigen al universo. En el caso de Anselmo se manifiesta la alquimia mental de una manera para aplicarlas de manera irresponsable y desorganizada, por lo que los efectos, lejos de a una prosperidad y desarrollo espiritual, lo conducen a su ruina. 


\section{CAPÍTULO VI}

"Un alma en pena": Naturaleza universal y dimensiones espaciales

La mente infinita del Todo es la matriz de los universos.

El kybalión

The diversity of the phenomena of nature is so great, and the treasures hidden in the heavens so rich, precisely in order that the human mind shall never be lacking in fresh nourishment.

Johannes Kepler

I wished to show that space-time is not necessarily something to which one can ascribe a separate existence, independently of the actual objects of physical reality. Physical objects are not in space, but these objects are spatially extended. In this way the concept of "empty space" loses its meaning.

Albert Einstein

El cuento "Un alma en pena" (1862) de Alejandro Tapia y Rivera trata sobre a historia del amor inmortal entre Alfredo y Amelia. Esta se ve obligada a cumplir con un matrimonio por conveniencia, pero muere el día de su boda. Sin embargo, el amor que ha dejado en este mundo ---Alfredo--- impide que su alma alcance el descanso eterno, por lo que se comunica con este desde la ultratumba. Alfredo pierde todo interés en la vida y sólo desea reunirse con su amada en el más allá, pero Amelia le advierte que el suicidio no es el camino correcto de un cristiano y que le cerraría las puertas del cielo. Alfredo, encuentra otro camino, se alista en el ejército y va a la guerra, donde resulta herido y muere. Finalmente Ulrico, su mejor amigo, ve cómo el alma 
de Alfredo sube una escalera celestial y se reúne con su amada, donde son recibidos por el propio Jesucristo, quien bendice la unión.

A primera vista, la lectura se nos presenta como una obra muy característica del romanticismo. Tal parece como si Tapia siguiera al pie de la letra la fórmula para escribir una historia que reúna los rasgos más típicos de este periodo literario: lugares y entornos tenebrosos, protagonistas agobiados por la soledad y marcados por un destino fatal, todo salpicado por el gusto por lo fúnebre y melancólico. Como ya se ha advertido, para el romántico los ambientes tenebrosos son un elemento esencial, por lo que esta descripción conecta perfectamente con esa tendencia por los espacios desolados, nocturnos y sepulcrales.

La obra comienza con la descripción de una tarde aletargada que va cediendo paso a la noche. Entre las sombras de los sepúlcros se distingue a la ninfa Mob, "envuelta en blanco sudario", ofreciéndole a Alfredo una copa envenenada, mientras se escucha una "música agradable, pero en lontananza, como un eco perdido, como un dulce pasado que no volverá" (1). Nos vamos adentrando en una historia sombría, en la que en un lugar indeterminado aparece una ninfa que le ofrece una copa de veneno al protagonista, al tiempo en que entre las sombras se escuchan las mujeres que Alfredo ha amado, y las voces de un amigo que lo incita a buscar la gloria, la voz de un anciano que le advierte sobre los desengaños de la vida, y la voz de un joven desencantado que lo invita a vivir y gozar el momento. Es una escena alucinante, que de entrada nos hace preguntarnos si estamos 
ante la realidad o ante una alucinante secuencia onírica del personaje principal.

Conviene señalar que la historia presenta una singular estructura, construida mediante diálogos y escenas de corte teatral, escritas en prosa, y presentadas en capítulos a manera de novela. En su estudio sobre la literatura fantástica puertorriqueña del siglo XIX, Héctor J. Martell Morales plantea que la escasa crítica que existe sobre este cuento se ha centrado en debatir la idea generalizada de que en Puerto Rico no se generó una literatura fantástica. Sin embargo, el propio Tapia publicó dos cuentos que catalogó como cuentos "fantásticos": "El purgatorio de un ególatra" (1878) y, en particular, el cuento que aquí nos ocupa ${ }^{51}$ En "Un alma en pena", aparecen muchas de las características de este género; en primer lugar, la historia es narrada por un testigo de los hechos, y nos presenta visiones e impresiones auditivas de los acontecimientos. Tapia y Rivera hace uso de un vocabulario que se identifica frecuentemente con la literatura fantástica. ${ }^{52} \mathrm{Si}$ a esto le añadimos que "en algunos momentos no se sabe si lo que ocurre es verdad, realidad, alucinación o algún otro fenómeno" debido a la confusión

\footnotetext{
51 "El purgatorio de un ególatra" es la narración del alma atormentada de un hombre rico, cuyo egoísmo en vida lo lleva a esconder todas sus riquezas para que luego de su muerte nadie disfrute de ellas. Su hija es condenada a una sufrida existencia, sin embargo, luego de la muerte de esta, el alma del padre se redime gracias al amor y al perdón de la joven.

${ }^{52}$ Palabras como alma, sepulcro, decadencia, éxtasis, melancolía, fúnebre, alucinación, muerte, féretro, locura, lágrimas, amargura y fantasma, entre otras (Martell Morales 175).
} 
entre la realidad y el ensueño de nuestro protagonista, podemos cocluir, según Martell Morales, que estamos ante un cuento fantástico (175).

Resulta pertinente destacar que, en "Un alma en pena" encontramos (al igual que en la historia de Póstumo el transmigrado) la temática espiritista. Saldivia-Berglund opina que "Un alma en pena" ofrece muchas capas de interpretación, puesto que entrelaza voces de personajes mitológicos con las de la gente común, y es probablemente el antecesor de un relato tapiano más extenso: "Enardo y Rosael o el amor a través de los tiempos" (1872), en el que se cuenta el relato de dos amantes que reencarnan en diversas épocas a través de la historia de la humanidad, para así continuar su idilio (40-41). De todo lo anterior se desprende que "Un alma en pena" es una obra de corte romántico, la cual puede leerse como una historia fantástica, influenciada por la popularidad del espiritismo de la época. No obstante, una relectura nos lleva a considerar su relación con la filosofía hegeliana y la tradición esotérica.

A partir de la muerte de Amelia, Alfredo se aleja de todo lo que había compuesto su mundo hasta entonces. Una noche, mientras se paseaba frente a la que fuera la casa de su amada, se le aparece un espectral monje encapuchado que le tiende una "mano amarilla como la cera" que "contenía un papel a manera de carta" (6-7) Era una comunicación de Amelia en la que le decía que dejara de llorar. La muerte la había hecho suya para siempre, pero no todo era bienandanza. Su espíritu se encontraba en un limbo; estaba atrapada en un espacio intermedio al no poder olvidar el amor que sentía por 
Alfredo. Sólo este podría ayudarla. La carta estaba acompañada de un rizo de sus cabellos y una azucena de su corona fúnebre; con esto, Alfredo "tenía pruebas en su mano...", tenía la materia que le llevaría al espíritu. Ahora sólo necesitaba encontrar la manera de invocar a su amada; "recordaba la posibilidad de la transfiguración descrita por los sabios como un fenómeno positivo" (8).

Alfredo se entrega en cuerpo y alma a la búsquedad de una fórmula que le uniera con Amelia. En un febril soliloquio evoca arcanos conocimientos de los que se desprenden múltiples claves para una lectura de corte hermético. Alfredo intenta "convencerse de la existencia de lo invisible y su contacto con las pobres formas de la materia" (8). Es decir, se pregunta si es posible la comunicación entre lo humano y lo sobrenatural. Comencemos por analizar estos primeros renglones a la luz del pensamiento hegeliano para luego establecer la presencia hermética en la obra.

De acuerdo con Hegel, todo comienza con una gran fuerza inmutable llamada "espíritu" (Geist). El espíritu, el cual constantemente va en busca de la perfección, es la razón misma. Hegel considera que la razón hace que la conciencia se acomode a los fenómenos particulares en categorías universales. Sin embargo, este proceso no es uniforme y siempre implica un elemento de incertidumbre y vaguedad, ya que los objetos existen en un espectro de variaciones y no se adaptan fácilmente a diferentes categorías universales. Los mundos astrales poseen una densidad mucho menor y una vibración más alta que el mundo físico de la materia. La conciencia está 
orientada a las categorías estables de pensamiento y también es consciente de un conjunto de normas que rigen la manera en que estos fenómenos se ajustan a estas categorías.

En el hermetismo todo cuanto comprende el cosmos se encuentra relacionado internamente, es decir, todo está enlazado de alguna forma u otra. Existen fuerzas ---como la energía o la luz--- que atraviesan y unifican todos los niveles de la existencia. Como ya hemos visto, la hermética nos dice que desde la más elevada manifestación, hasta la más inferior, todas vibran. Los grados de la frecuencia de las vibraciones constituyen los grados de la medida en la escala de vibraciones. $Y$ estos grados forman lo que los ocultistas llaman planos. El átomo, la unidad de fuerza, la mente del hombre y los seres angelicales no son sino grados en una escala, y son todos fundamentalmente lo mismo, siendo la diferencia únicamente una cuestión de grado y de frecuencia de vibración; todos son creaciones del Todo, y tienen su existencia dentro de la mente infinita del Todo. El gran plano físico es esa división de los fenómenos del universo que incluye todo lo que se relaciona con las fuerzas y manifestaciones materiales e incluye todas las formas de eso que llamamos materia, junto con todas las formas de energía o fuerza (El kybalión 12). ${ }^{53}$ Por su parte, Hegel advierte que no debe

\footnotetext{
${ }^{53}$ Conectando esta aseveración con la ciencia física, nos referimos al renombrado físico Brian Greene, el cual señala que para Einstein, la meta de la unificación, de explicar la más amplia gama de fenómenos físicos con la menor cantidad de principios, se convirtió en una pasión de toda la vida. Con sus dos teorías de la relatividad, Einstein unió espacio, el tiempo y la gravedad. Sin embargo, este éxito solo le animó a pensar más grande: "he dreamed of finding a single, allencompassing framework capable of embracing all of nature's laws; he called that framework a unified theory" (16).
} 
concebirse la Naturaleza como algo creado y mantenido por algo que no sea o esté en sí mismo, es decir, como algo que descanse sobre un fundamento extraño, ajeno y que, como tal, carezca de fundamento (Hegel, Lecciones sobre la historia de la filosofía 283).

En el relato que nos concierne, el protagonista enuncia la palabra "sobrenatural" y propone que es este es un concepto que no debería existir puesto que: "¿qué podrá vislumbrar el hombre que no quepa dentro de su naturaleza?" (8). Alfredo plantea que todo cuanto el hombre pueda vislumbrar cabe dentro de la Naturaleza, lo que supone una realidad en un espacio y tiempo ilimitado, por lo que exclama: " La realidad infinita! Ese mismo infinito ¿no es también concepción humana? Esa realidad ¿qué es sino un espacio que llama al espíritu a ser ocupado por él?" (8) Pero esa "realidad infinita" es también una concepción de la mente humana que el espíritu debe llenar. Por tanto, eso que llamamos "sobrenatural" no es sino parte de la Naturaleza misma. Este argumento nos lleva a retomar la filosofia hegeliana, la cual explica que todos los cuerpos son pesados, es decir, que poseen un eje central, lo que significa que todo cuanto existe busca una unidad con su propio ser:

Matter, since it strives to suspend its mutual externality and to become wholly ideal, strives therefore to negate its reality, and that would occur if it arrived at its unity. This is the misfortune of matter: to strive eternally for a unity that it never attains. In contrasts, spirit, in its freedom, attains its center wherein it 
comes to existence (for I am for myself, I am the whole universe and my object is also I). On the other hand, matter is mutual externality. The concept in nature is just this: to overcome this mutual externality. The highest point to which nature attains in this overcoming is life, feeling. Sentience is an achievement that still falls within nature. (Hegel Lectures 75)

Como parte de la exterioridad de la Naturaleza, el tiempo y el espacio no son conceptos puramente lógicos, sino que deben verse como categorías abstractas. Para Hegel, todo existe y se desarrolla en el tiempo y el espacio. Por lo tanto, la Naturaleza es una contradicción, existe y no existe a la vez, ya que no tiene contrapartida puesto que todo forma parte de esta. ${ }^{54}$ Cada etapa, fase o momento es solo un fragmento, y por lo tanto, es falso parcialmente:

Likewise, nature is the untrue existence of the concept because the concept is the center that is immanent and because reality does not correspond to the concept, but is here material. We can see without any qualification that since nature is the untrue, the self-contradictory, it cannot remain [mere nature]. Rather the

\footnotetext{
${ }^{54}$ La idea de Hegel es la "totalidad", que conserva en su interior cada una de las ideas o etapas que ha superado o sublimado. La sublimación es un proceso de desarrollo formado por "momentos" (etapas o fases). Hegel explica lo que sucede cuando una tesis y una antítesis interactúan, sobre todo a través del término "sublimar", una traducción de "aufheben", término alemán que significa "negar" o "eliminar". Pero en este proceso se conservan los elementos primarios de manera parcial, ya que no son eliminados sino que están contenidos en el nuevo principio superior que los ha sustituido. La totalidad es el producto de dicho proceso que conserva todos sus "momentos" como elementos de una estructura.
} 
concept in nature presses on to make a true existence of itself. The concept is a center that drives itself to come to the surface, to supersede mutual externality or conversely, nature returns into itself in order to attain its center. (Hegel, Lectures 74-75) Alfredo intenta encontrar una forma de evocación, una posibilidad de transformación; argumenta que si: "La materia, lo denso, siendo infinito, cabe en la Naturaleza, ¿por qué no, lo espiritual, lo sutil?” (8). Para que pueda darse el proceso de materialización, el espíritu por medio de su libertad debe centralizarse, "sintiéndose", es decir, que Alfredo, pensando en Amelia, sintiendo su presencia, podrá hacer que esta entre en el ámbito de lo denso y de lo natural, como si se abriera una puerta que conectara esos dos niveles o dimensiones de existencia. Por lo que no es de sorprender que el protagonista estuviera convencido de que mediante su pensamiento podría "materializar" a su amada. El propio Tapia y Rivera explica este fenómeno de la siguiente manera:

El espíritu humano tiene el don de transformar la Naturaleza pensándola, es decir, considerándola como objetivo de su pensamiento. Si al pensarla, que es lo mismo que idealizarla, porque la convierte en idea, éntra [sic] en el examen de las leyes que determinan su existencia, sus funciones ó [sic] su fin utilitario, semejante investigación girará en la esfera de la verdad racional y real, porque no se ciñe á [sic] la apariencia; pero si al pensarla, la siente y la idealiza prescindiendo de 
aquellas leyes y ateniéndose sólo á [sic] la apariencia, aquel sentimiento-idea girará en la esfera de lo aparente, y al realizarse, sin dejar de ser tan verdad como la racional, será sólo una verdad sensible. (Conferencias 10)

Si conectamos esta idea del proceso de materialización mediante el pensamiento con el principio hermético de la correspondencia, vemos cómo este incorpora la idea de que hay siempre una reciprocidad entre las leyes y fenómenos de los diversos planos de vida y existencia, y la utilización de este principio provee uno de los medios para solucionar muchas paradojas y secretos de la Naturaleza. Hay planos más allá de nuestro conocimiento, pero cuando les aplicamos el principio de correspondencia, somos capaces de entender mucho de lo que de otro modo nos habría sido incognoscible. Este principio puede aplicarse y manifestarse en los diversos planos del universo material, mental y espiritual. Los antiguos herméticos lo consideraban uno de los más importantes instrumentos mentales por los que el hombre era capaz de razonar inteligentemente desde lo conocido hasta lo desconocido. (El kybalión 26).

Hegel separa la conciencia del hombre de la Naturaleza, la convierte en algo absoluto, la deifica. Considera el mundo material como un producto de la actividad de una conciencia sobrehumana, tal como el "otro ser del espíritu". El fundamento de todos los fenómenos de la Naturaleza y de la sociedad es el espíritu universal. Según Hegel, el espíritu universal es lo primario, es eterno; la Naturaleza es lo secundario y derivado del espíritu. 
Hegel lo denomina también idea absoluta, "espíritu absoluto" y "conciencia de Dios". A su juicio, el movimiento, el desarrollo, existe únicamente porque todo se halla dirigido por cierta conciencia sobrenatural, la cual piensa, crea los conceptos, se reconoce a sí misma a través de su movimiento, y engendra la Naturaleza en este proceso de movimiento. Resulta necesario recordar que Hegel se opone a la afirmación agnóstica de Kant, de que las "cosas en sí" se encuentran "más allá" de nuestro pensamiento, es decir, de que son incognoscibles, puesto que el pensamiento es capaz de conocer la verdad: El ser y el no ser como algo pensado, como algo representado ante la conciencia en el sentido de cosas distintas relacionadas entre sí, como o lleno y lo vacío, no acusan diferencia alguna, pues también lo lleno entraña, evidentemente, la negatividad en sí mismo, es un ser para sí que excluye todo lo otro, es lo uno y una multiplicidad infinita de unos, mientras que lo vacío no es lo excluyente, sino la continuidad pura. (Hegel, Lecciones sobre la filosofía de la historia 82)

Aclarados estos conceptos hegelianos, vemos cómo en su monólogo Alfredo exclama: “ $\mathrm{A} A$ ! cuando en mi mente la veo en sueños ¿qué es sino lo sobrenatural en lo natural, qué es sino la realidad de un ciclo que cabe y llevo dentro de mi corazón?" (8). La amada se le aparece en sueños, pero estos sueños son imágenes que pasan a formar parte del mundo natural, pues el dormir y el soñar pertenecen a una experiencia común a todo ser humano. Entonces, esas imágenes quedan impresas en su corazón, permaneciendo 
fijas en esta humana y "natural" dimensión. Aquí también vemos la influencia del pensamiento hegeliano en la obra tapiana:

The images that we have in sleep are dreams. People have wondered whether the soul is active in sleep. Spirit, soul, is essentially activity, not a thing, not an abstract, self-relating, reflective, quiescent dead being; rather spirit is eternal movement... So everything exists in feeling. It is in the heart, the complex feeling; it is in me as this singular. Principles must be in the heart, which means they belong to my being so that I am inseparable from this content. If I merely know about it, then it is not identical with my very being and immediacy. I must be it. This inseparability is necessary. We have this inseparability also in our images. (Hegel, Lectures 112)

Es decir, que al poner Tapia en labios de su protagonista este postulado, reafirma la idea de que existe una unidad en todo cuanto existe. La Naturaleza y sus leyes abarcan el tiempo, el espacio y todas sus dimensiones. Amelia ya no se encuentra en el mundo físico, pero eso no significa que haya dejado de existir, pues esas leyes naturales de reciprocidad presagian la posibilidad de un encuentro. Si pensamos en una explicación hermética, encontramos en el libro de Asclepio que:

La sensación y la inteligencia, entrelazadas, confluyen en el hombre, pues para poder pensar se requiere de ambas, sensación e inteligencia. Pero ¿no se podría pensar en una 
intelección sin el concurso de la sensación, como cuando en sueños imaginamos visiones? A mí me parece, que, nacidas ambas energías en la visión del sueño, se despiertan precisamente por la sensación, y una parte de la sensación va al cuerpo y otra al alma, y cuando ambas partes de la sensación concuerdan entre sí, se expresa nuevamente el pensamiento, parido por la inteligencia. Porque la inteligencia da a luz todos los pensamientos. (Los libros de Hermes Trismegisto 99)

Los sueños son el vínculo que mantenemos con el mundo espiritual mientras nos encontramos en el mundo físico. Nos dan una idea de cómo es el mundo en que vivimos y nos ayudan a formar nuestras experiencias terrenales.

Alfredo continúa reflexionando y concluye que: "El sólido enlazado al líquido, el líquido al vapor, el vapor al éter, el éter a los mundos diáfanos e invisibles, he ahí la cadena" (8). Todo acontecimiento es un eslabón presente en la gran cadena de sucesos que fluyen de la energía creadora del todo. Hay una continuidad entre todos los acontecimientos precedentes, consecuentes y subsecuentes. Existe siempre una relación entre todo lo que ha ocurrido y todo lo que continúa ocurriendo. Y aquí llegamos a una importante coyuntura entre el pensamiento hegeliano y la antigua corriente del pensamiento hermético, el famoso precepto contenido en la llamada Tabla de Esmeralda de Hermes: "En verdad ciertamente y sin duda, lo que está abajo es como lo que está arriba, y lo que está arriba es como lo que 
está abajo", y es este principio o proposición hermética la que recita (casi verbatim) Alfredo cuando en su discurso proclama: "Lo que está en lo alto es como lo que está en lo bajo; lo que está encima es como lo que está debajo" (Tapia y Rivera 8). La filosofía hermética considera que el universo puede dividirse en tres grandes clases de fenómenos, conocidos como los tres grandes planos: el físico, el mental y el espiritual. Estas divisiones son más o menos artificiales y arbitrarias, pues la verdad es que son sólo grados ascendentes de la gran escala de la vida, cuyo punto más bajo es la materia, y el más elevado es el espíritu. Más aún, los diferentes planos se solapan, de modo que no puede hacerse ninguna división clara entre los fenómenos superiores del plano físico y los inferiores del mental, o entre los superiores del mental y los inferiores del espiritual. Todo lo que está incluido en el universo emana de la misma fuente, y las mismas leyes, principios y características se aplican a cada unidad o combinación de unidades, conforme cada una manifiesta sus propios fenómenos sobre su propio plano.

Es precisamente a esta continuidad a la que Alfredo se refiere al ponderar este secreto: "La síntesis egipcia, la serpiente que muerde su cola. La antigüedad de este misterioso jeroglífico es su mejor testimonio" (8). Este es uno de los símbolos más emblemáticos del hermetismo, el uróboros, el cual muestra a una serpiente o dragón engullendo su propia cola y formando así un círculo. De esta forma se expresa la unidad de todas las cosas, las materiales y las espirituales, que nunca desaparecen sino que cambian de forma en un ciclo eterno de destrucción y nueva creación. En algunas 
representaciones antiguas aparece con la inscripción griega " $\varepsilon \vee$ to mav" (hen to pan), es decir todo es uno, y representa la naturaleza cíclica de las cosas, el eterno retorno y otros conceptos percibidos como ciclos que comienzan de nuevo en cuanto concluyen. En un sentido más amplio simboliza el tiempo y la continuidad de la vida. De hecho, Hegel describe su sistema lógico como un "círculo de círculos", y la circularidad "is a perennial image associated with Hermetic and mystical thought. Interestingly, the phrase he kai pan or hen to pan is associated with the alchemical symbol of the ouroburos" (Magee 10102).

En su libro The Great Mother: An Análisis of the Archetype, Erich Neumann plantea que el uróboros, la serpiente circular que se muerde la cola, es el símbolo del origen, del principio, que a su vez contiene dentro de sí los símbolos de lo opuesto. El uróboros es el gran círculo en el que los elementos positivos y negativos, el hombre y la mujer, la conciencia y los elementos del inconsciente se entremezclan. En este sentido, el uróboros es también símbolo de un estado en el que el caos, el inconsciente y la psique son una especie de "todo" indiferenciado (17-19). Con anterioridad, Julius Evola había visto en este principio la representación de la unidad cósmica. El símbolo alquímico simboliza lo "Uno en el Todo", el círculo, línea o movimiento que se encierra en sí mismo y que en sí mismo tiene principio y fin. En el hermetismo, este gráfico, toma la forma de una serpiente que se muerde la cola, una serpiente venenosa, de acuerdo con su doble significado. En el círculo externo se lee: "Uno es el todo, por medio de él el 
todo, y para con él el todo: si el todo no contuviera el todo, el todo no sería nada" (26). Este todo ha sido llamado también caos y huevo, porque contiene indistintamente las potencialidades de todo desarrollo o generación, y se encuentra en lo profundo de cada ser y en la multiplicidad caótica de las cosas y de las formas dispersas aquí abajo, y en el espacio y en el tiempo. Por otra parte, el círculo del uróboros comprende también otro significado, puesto que alude al sello hermético:

La naturaleza se recrea en la naturaleza, la naturaleza vence a la naturaleza, la naturaleza domina a la naturaleza. Si declaramos espiritual nuestra materia, es cierto; si la declaramos corporal, no mentimos. Si la llamamos celeste, es su verdadero nombre. Si la denominamos terrestre, hablamos con propiedad. (26)

De esta misma forma, Alfredo, sintiendo una especie de caos o confusión mental y espiritual, concluye con una súplica a manera de oración casi panteísta en la que le implora a Dios (el Todo) que le conceda la visión de su amada: “¡Dios mío! Que yo la vea, como te veo Señor infinito, ya que has permitido que mi mente te alcance, ya que has querido que te vea en ella, como en tu obra" (Tapia y Rivera 8). El principio y el fin se confunden en un todo que llama "Dios", al cual pide le conceda correr el velo del misterio, de lo oculto. ${ }^{55}$

\footnotetext{
${ }^{55}$ El uróboros se relaciona con la diosa Isis. Los antiguos herméticos consideraban el principio de la correspondencia como uno de los más importantes instrumentos mentales por los que el hombre era capaz de llegar a conocer lo desconocido,
} 
Curiosamente, Alfredo pide verla de la misma manera en que ve a Dios en toda la creación ---de la cual Amelia forma parte--- y continúa diciendo: "Que venga a mí atraída a estos ojos de mi cuerpo, por esa cadena impalpable que me une contigo y a ella por los de mi alma" (8). Resulta interesante destacar aquí, que de acuerdo al hermetismo, "toda alma es inmortal y está siempre en movimiento" (Los libros de Hermes Trismegisto 248), "la muerte sería la destrucción y nada se destruye en el mundo" (Tapia y Rivera 97). Por lo tanto, la muerte no existe. Mas siendo Alfredo un hombre fiel a la doctrina cristiana de su época, utiliza su discurso religioso y puramente dogmático para apelar al "infinito" e incluso aquí podemos ver la huella hegeliana en Tapia, ya que:

Cristo es para Hegel, no solamente un modelo histórico de una religión popular fundada en el amor, sino ---lo que es más importante--- el ejemplo máximo de una dialéctica plenamente experimentada de separación y unión. No solamente descubre Hegel en los tiempos de Cristo la misma constelación de desgarramiento político-religioso que caracterizaba los siglos XVIII y XIX, sino que Cristo se convierte en modelo eterno de todo tipo de reconciliación. (Kerkhoff 54)

Según Hegel, la teología cristiana también ha concebido a Dios, es decir, a la verdad, como espíritu, no como un ser inmóvil que permanece encerrado en su unidad abstracta, sino como un ser que entra reflejo de la cara de la diosa (Kybalión 25). 
necesariamente en este proceso. Dios mismo se diferencia, se apoya en su contrario y busca su propia unidad por medio de ese contrario y por su supresión, por una supresión en la que no se separa de su contrario, pero lo envuelve y lo conserva en su unidad. La teología explica este proceso bajo la forma de representación, mostrando a un Dios Padre, ese ser universal que permanece dentro de sí mismo, mas renunciando a su existencia solitaria, crea la Naturaleza (el ser exterior a sí mismo y colocado fuera de sí mismo), y luego crea a su hijo (su otro yo). Pero en virtud de su amor infinito se contempla a sí mismo en este contrario en el que reconoce su propia imagen, y vuelve a su unidad, unidad que no es ya la unidad absoluta e inmediata, sino la unidad concreta que sale de la diferencia y de la mediación del padre y del hijo, y que en la comunidad cristiana es el Espíritu Santo, es el espíritu que ha entrado en posesión de su verdad y su realidad absoluta. (Filosofía del espíritu Hegel, 104). Retornando a nuestro protagonista, encontramos que este, en un momento de desesperación proclama cuánto ha amado a Amelia:

Cristo tuvo piedad de los que amaron mucho. Este amor fue una ley tuya. Aun cuando ella hubiese sumido su rostro en el fango de la tierra, aun cuando todos los elementos se hubiesen conjurado contra ella, yo la hubiera siempre levantado en mi corazón, porque la amaba y la amo mucho, ¿por qué no; siendo ella una de vuestras elegidas, purificándose y purificándome en el fuego de su alma? (Tapia y Rivera 8) 
Entonces se le aparece el espíritu de su amada, el cual parece susurrarle que " Morir por el bien del hombre no cierra el cielo; todo hombre puede encontrar un glorioso Calvario y después un paraíso!" (11). Así, encuentra Alfredo la solución. Ya que su creencia cristiana le impide suicidarse, pues su alma se perdería para siempre, se une a las filas de un ejército para luchar "por la humanidad" y muere a causa de sus heridas de guerra. Al final, su amigo y compañero de batalla, Ulrico, cuenta que le pareció ver el fantasma de un monje que bendecía la unión de Amelia y Alfredo.

Podemos concluir diciendo que tanto la filosofía del espíritu hegeliana como la simbología hermética describen el universo como un círculo que se cierra sobre sí mismo. Es un sistema de círculos cuyo conjunto se presenta como un círculo de círculos, cada uno de los cuales es un momento necesario que constituye la idea. La idea se representa en la Naturaleza, la cual se refleja en el espíritu, y el espíritu regresa a la idea de "espíritu absoluto" o, si se quiere, "Dios". De esta manera, Alfredo y Amelia encuentran la manera de unirse nuevamente, al trascender las aparentes barreras de los planos físicos, mentales y espirituales. 


\section{CONCLUSIONES}

Hemos visto en este estudio cómo el motor que pone en marcha los acontecimientos en las cuatro obras estudiadas es una muerte inesperada y la acción o reacción de los protagonistas ante esta. Todo esto se encuentra marcado por una "circularidad" que de alguna manera regresa a los personajes a su punto de partida, no sin antes hacerles experimentar un cambio interno. Además, a todos los personajes les une un rasgo común, la impulsividad de su carácter, el cual les lleva a tomar decisiones que les conducirán hacia mundos extraños donde las leyes naturales conocidas parecen dejar de operar.

Hemos comenzado con el cuento galdosiano, "Celín", en el que se nos relata el viaje literal y metafórico que realizan los protagonistas a través de la Naturaleza de Turris. Al comienzo puede advertirse cómo Diana se encuentra sumida en un estado emocional que desde el punto de vista hermético podría situarse en un polo emocional "negativo". La idea de suicidarse, a causa de la muerte de su amado, ocupa cada uno de sus pensamientos, pero Celín la conduce hasta un polo o estado emocional "positivo". Los acontecimientos vistos en términos herméticos encuentran explicación en los principios de vibración y de ritmo.

Trabajando con el principio del ritmo, el cual indica que todo fluye y oscila como el movimiento de un péndulo, y todo en el universo se encuentra en una constante transformación, los herméticos han aprendido a utilizar las fuerzas de la Naturaleza. Neutralizando los efectos del ritmo, se polarizan en 
el punto deseado. Además, han aprendido a controlar sus oscilaciones que van de un polo a otro. En cuanto al principio de vibración, los herméticos saben que elevando las vibraciones desde la más baja, que corresponde a la materia más densa, hasta la más alta, que corresponde al espíritu, pueden controlar sus propias vibraciones mentales y las de los demás. Es esto lo que Celín ha hecho con Diana. En la movediza ciudad de Turris todo cambia, se mueve y vibra, por lo que Celín utiliza esa sensación de aparente caos para distraer a Diana y así mostrarle las maravillas que la vida ofrece. Celín posee todas las características de un maestro hermético, puesto que también aplica estos principios para controlar los fenómenos naturales. Y es en el descubrimiento de la Naturaleza que se encuentra la clave. Hegel, al igual que los herméticos, opina que conociendo la Naturaleza hasta trascenderla nos convertimos en dueños de nuestro propio destino, que es precisamente lo que experimenta Diana al final de la historia. Conociendo la Naturaleza (la creación divina), el ser humano puede conocer los aspectos, instantes y momentos de Dios. (Magee 4). Es este el motivo de la circularidad que se representada en el recorrido geográfico de los personajes y finalmente, en la transformación de la protagonista. El conocimiento de la Naturaleza al cual la expone Celín, causa en esta la transformación necesaria que la hace escoger el camino de la vida. En términos herméticos, Diana cambia su vibración negativa, polarizándose hacia el extremo positivo de la escala vibratoria. 
En Póstumo el transmigrado vemos a un hombre que reencarna caprichosamente en el cuerpo de su enemigo, desobedeciendo las leyes divinas para tomar la justicia en sus propias manos; a partir de estos hechos se enfrenta al principio universal de la dualidad o polaridad, por lo que se ve obligado a afrontar múltiples retos para alcanzar una verdadera armonía existencial. En la segunda parte de la historia, Póstumo el envirginiado, el espíritu continúa con su voluntariosa actitud, esta vez invadiendo un cuerpo femenino. Ahora no solo se ve obligado a armonizar su existencia física y espiritual, sino que además debe enfrentarse al principio de la dualidad de los sexos y sus consabidas diferencias.

De acuerdo con el postulado hermético de la polaridad todo tiene dos polos o su par de opuestos que no son sino los extremos de la misma cosa. La doctrina expone que Dios (que es vida y luz) es bisexual, y que creó al hombre semejante a sí mismo, por tanto, el hombre también es bisexual. Pero el hombre se deja llevar por su atracción hacia la Naturaleza y la materia y así, junto con todas las demás criaturas, provocó una división en dos sexos. Sin embargo, si los hombres aprenden el camino de regreso a su estado de origen, su mente, después de la muerte del cuerpo, volverá de nuevo a través de las esferas celestiales a entrar en Dios; es decir, alcanzará la consumación mendiante el conocimiento. No obstante, El Transmigrado fracasa en su empeño de recrear la totalidad de su antigua existencia. Al reencarnar por la fuerza en cuerpos ajenos, no logra armonizar la materia con el espíritu y ni siquiera consigue su propósito inicial de venganza. Desde 
la perspectiva hermética, el alma de Póstumo no logra armonizar su dualidad. El hermetismo nos dice que la polaridad es una "paradoja divina", y quienes poseen el conocimiento pero no se "purifican", es decir, no se mueven hacia el polo positivo, solo consiguen la destrucción propia. Para Hegel la unión de lo individual y de lo universal, es una mezcla que guarda su existencia independiente frente a lo universal, con quien está al mismo tiempo en relación" y "contiene, por consecuencia, la contradicción multiforme de la individualidad". Solo así se logrará la integración de las cualidades supuestamente opuestas que necesariamente llevan a engendrar una nueva criatura, la que a su vez continuará engendrando, creando y recreando.

En La sombra vemos los postulados herméticos del mentalismo y de de causa y efecto. Según el primero, todo lo que es evidente a nuestros sentidos es producto de la mente, que a su vez emula la actividad de la gran "mente universal" o en términos hegelianos, la "Idea Absoluta". Si el universo es mental en su naturaleza, entonces la transmutación mental debe ser el arte de cambiar las condiciones del universo en los planos de la materia y de la mente. Si la "transmutación mental" o la "alquimia mental" es el arte de cambiar y transformar estados, formas y condiciones mentales, entonces vemos cómo Anselmo, sin proponérselo, hace uso de esta alquimia mental para transformar su realidad. Como ya hemos señalado, si la transforma a causa de una enfermedad mental o si en verdad ha creado un ente físico llamado Paris, no afecta el hecho de que ha utilizado el poder mental para 
efectos transmutadotes. No obstante, este principio actúa en conjunto al principio universal de la causalidad o "causa y efecto"; todo suceso se relaciona en última instancia con una secuencia infinita e ininterrumpida de acontecimientos relacionados. Anselmo, mediante el poder de su mente, crea una realidad fatídica que desemboca en un trágico final. A causa de dar rienda suelta a su pensamiento desenfrenado, acaba con la vida de su esposa y en un nivel metafórico, con la suya propia.

En "Un alma en pena", el protagonista intenta rasgar el velo del universo y sus misterios, para así explicar las comunicaciones del mas allá que ha experimentado. Pero, ¿dónde se encuentra ese más allá sino dentro de la propia naturaleza? Si Dios es el "todo" creador, eso que llamamos sobrenatural no es más que parte de la creación divina. Estudiando las leyes y principios universales, Alfredo llega al entendimiento de que todo lo que está abajo (en el mundo material) es igual a lo que está arriba (en el mundo espiritual) y viceversa. Este precepto declara una armonía, acuerdo y correspondencia entre los diferentes planos de manifestación universal, que la filosofía hermética considera puede dividirse en tres grandes clases de fenómenos, conocidos como los tres grandes planos, a saber: el físico, el mental y el espiritual, y asegura que todo lo que está contenido en el universo emana de la misma fuente, por lo que las mismas leyes, principios y características se aplican a todo cuanto existe.

Existe una constante relación o comunicación entre los diversos planos de existencia, y podemos sintonizarnos en determinada frecuencia y 
así abrir el "portal" interdimensional. Utilizando la razón, el hombre observa lo conocido y deduce lo desconocido. En el hegelianismo encontramos que, aunque vivimos en un universo en el que todo se encuentra organizado jerárquicamente, existen energías cósmicas que lo relacionan y unifican todo mediante fuerzas o poderes divinos. Esta correspondencia habilita al hombre para razonar inteligentemente desde lo conocido hasta lo desconocido.

Alfredo descubre que todo en el universo está interrelacionado y que, como indica el hermetismo, el ser humano es un macrocosmos que se refleja en el microcosmos, que es el ser humano. Tapia conoce muy bien esta máxima hermética, y hace que su protagonista la invoque para demostrarse a sí mismo que no existe nada sobrenatural, y que todo lo creado se encuentra dentro de la Naturaleza. El lugar adonde ha ido Amelia es parte de lo creado por Dios, entonces hay esperanza de que Alfredo pueda reunirse con ella. Podemos concluir que cada una de las partes de la filosofía del espíritu hegeliana y de la simbología hermética es un todo filosófico, un círculo que se cierra sobre sí mismo. En otras palabras, la idea se representa en la naturaleza, la cual se refleja en el espíritu, y el espíritu regresa a la idea del "espíritu absoluto" o, si se quiere, regresa a "Dios".

Finalmente, en el análisis de estas obras hemos visto las huellas del pensamiento esotérico de la época, el cual se encuentra firmemente afianzado en la tradición hermética. Con esto no pretendemos afirmar que, en efecto, Alejandro Tapia y Rivera y Benito Pérez Galdós escriben de acuerdo a los mencionados preceptos herméticos. Tampoco quiere esto decir 
que el pensamiento hegeliano sea la causa directa de estas características. Sí podemos concluir que las obras estudiadas se prestan a una lectura hermética que abre las posibilidades de interpretación de ambos autores, y nos permiten explorar diversos aspectos metafísicos que a primera vista podrían considerarse meros inventos literarios. Podría aducirse que a cualquier obra, irrespectivamente de su temática o periodo literario respondería a este tipo de lectura esotérica. Tal vez sea cierto, pues en todo momento hemos destacado el carácter universal de estos postulados. No obstante, en las obras estudiadas podemos ver de manera patente los principios herméticos en acción.

El Celín galdosiano vibra, cambia y se encuentra en constante movimiento. De igual manera el Póstumo tapiano se nos presenta como un inquieto espíritu que busca polarizarse en determinado punto de la escala vibratoria para así lograr armonizar su dualidad. En el primer caso vemos cómo Celín logra su cometido utilizando el principio del ritmo y el de la vibración para disuadir a Diana de sus fatales planes originales. Póstumo, por su parte, no logra unificarse en ninguna de sus dos encarnaciones, ya que no comprende que el fin último no es la venganza ni la violencia, sino la paz de la esencia espiritual. Entretanto, Anselmo inadvertidamente utiliza el mentalismo para crear una realidad que provocan consecuencias desastozas, ya que no se hace responsable de sus actos (sean estos causados por una enfermedad mental o no). Sin embargo, Alfredo, triunfa en su afán de trascender las supuestas barreras entre los diversos planos de 
existencia, ya que descubre que todo lo que existe es parte de la Naturaleza creada por una misma Divinidad. 


\section{LIST OF REFERENCES}

Abrams, M.H. Natural Supernaturalism: Tradition and Revolution in Romantic Literature. New York: W.W. Norton \& Company, Inc., 1971. Impreso.

---. The Mirror and the Lamp. New York: Oxford University Press, 1953. Impreso.

Alas, Leopoldo. Clarín. Ensayos sobre Galdós. Madrid: Fundamentos, 2001. Impreso.

Aponte Alsina, Marta. "Póstumo interrogado: relectura de Tapia." Tapia ayer y hoy: Edición conmemorativa 1882-1982. Santurce, Puerto Rico: Universidad del Sagrado Corazón, 1982. 43-79. Impreso.

Andreu, Alicia G. Modelos dialógicos en la narrativa de Benito Pérez Galdós. Amsterdam/Philadelphia: John Benjamins Publishing Company, 1989. Impreso.

Armstrong Crow, John. Spain The Root and the Flower - An Interpretation of Spain and the Spanish

Austin, Karen. "Don Anselmo and the Author's Role." Anales Galdosianos 18 (1983): 39-47. Web.

Beauchamp, José Juan. Imagen del puertorriqueño en la novela. Puerto Rico: Editorial Universitaria, 1977.

Bauer, Nancy. "Debating Legacy for Contemporary Feminist Politics". Hegel's Philosophy and Feminist Thought: Beyond Antigone? New York: Palgrave Macmillan, 2010. Impreso.

Beauvoir De, Simone. El segundo sexo. Trad. Juan García Puente. Buenos Aires: Editorial Sudamericana, 1999. Impreso.

Beiser, Frederick C. The Cambridge Companion to Hegel and NineteenthCentury Philosophy. Cambridge: Cambridge University Press, 2008. Impreso.

Benítez Rojo, Antonio. "Prólogo." Póstumo el transmigrado: historia de un hombre que resucitó en el cuerpo de su enemigo. Alejandro Tapia y Rivera. Barcelona: Galaxia Gutenberg, Círculo de Lectores, 1998. 723. Impreso. 
Bernabé Riefkhol, Rafael. "Género y frontera: Póstumo el transmigrado de Alejandro Tapia y Rivera”. Revista de Estudios Hispánicos. San Juan: Universidad de Puerto Rico, 1993. 233-52.

Blackburn, Simon. The Oxford Dictionary of Philosophy. Oxford: Oxford University Press, 2005. Impreso.

Bravo-Villasante, Carmen. Galdós visto por sí mismo. Madrid: Editorial Magisterio, Español, S.A., 1970. Impreso.

Broek, Roelof y Cis. Heertum. From Poimandres to Jacob Böhme: Gnosis, Hermetism, and the Christian Tradition. Amsterdam: Bibliotheca Philosophica Hermetica, 2000. Impreso.

Broek, Roelof y Hanegraaff, Wouter J. Gnosis and Hermeticism from Antiquity to Modern Times. New York: SUNY Press, 1998. Impreso.

Brau, Salvador. Hojas caídas. San Juan, Ensayos (Disquisiciones sociológicas). Río Piedras: Editorial Edil, 1972. Impreso.

Butler, Judith. Gender Trouble: Feminism and the Subversion of Identity. New York: Routledge, 1999. Impreso.

Calton, Patricia Marie. Hegel's Metaphysics of God. The Ontological Proof as the Development of a Trinitarian Divine Ontology. Burlington: Ashgate, 2001. Impreso.

Cardona, Rodolfo. Introducción. La sombra. By Benito Perez Galdós. New York: W. W. Norton, 1964. xv-xxxii. Impreso.

Casalduero, Joaquín. Vida y obra de Galdós. Madrid: Editorial Gredos, 1951. Impreso.

Castro Pérez, Elsa. Tapia señalador de caminos. San Juan, Puerto Rico: Editorial Coquí, 1972. Impreso.

Cerezo Paredes, Alicia. "Cada espíritu es un libro": Spiritualism in Turn-ofthe-Century Spain." Decimonónica.10. NUM.1 (2013): n. page. Web. 1 Oct. 2013.

Clavería, Carlos. "Sobre la veta fantástica en la obra de Galdós". Londres: Atlante, I 1953. 78-86 y 136-43.

Corbière, Eugene. La masonería: política y sociedades secretas. Buenos Aires: Editorial Sudamericana, S.A., 1998. Impreso. 
Córdova Iturregui, Félix. "A propósito de Alejandro Tapia: La ciudad ausente o las visiones de un cegato." Revista de estudios hispánicos, UPR 29.1-2. (2002): 25-32.

Correa, Gustavo. Realidad, ficción y símbolo en las novelas de Pérez Galdós: Ensayo de estética realista. Bogotá: Instituto Caro y Cuervo, 1967. Impreso.

Cruz Rivera, Yasmine. Pasión y letra: Ensayos de crítica literaria sobre la literatura puertorriqueña. San Juan: Editorial Cultural, 2004. Impreso.

De Jongh-Rossel, Elena. El krausismo y la generación del 1898. Valencia: Chapel Hill, Ed., 1985. Impreso.

De Jesús, Santa Teresa. Obras completas Madrid: B.A.C., 1962. Impreso.

Dible II Randolph T. "The Philosophy of Mysticism: Perennialism and Constructivism". Journal of Consciousness Exploration \& Research. 1.2 (2010): 173-183. Impreso.

Ebeling, Florian. The Secret History of Hermes Trismegistus: Hermeticism from Ancient to Modern Times. Ithaca: Cornell University Press, 2007. Impreso.

Eoff, Sherman. The Novels of Pérez Galdós; The Concept of Life as Dynamic Process. Saint Louis: Washington University Studies, 1954. Impreso.

---. "Galdós in Nineteenth-Century Perspective." Anales Galdosianos. Web. 30 sep. 2012.

Evola, Julius. The Hermetic Tradition: Symbols and Teachings of the Royal Art. Vermont: Inner Traditions International, 1995. Impreso.

Ezama-Gil, Ángeles, "La invención del espacio en un cuento Maravilloso galdosiano: el Madrid de 'Celín"' Anales del Instituto de Estudios Madrileños. 33. (1993): 617-627.

---. "El manuscrito de 'Celín': análisis crítico de un cuento maravilloso galdosiano" Actas del Quinto Congreso Internacional de Estudios Galdosianos. (1988): 91-97.

Faivre, Antoine. Theosophy, Imagination, Tradition: Studies in Western Esotericism. Albany: SUNY Press, 2000. Impreso. 
Fernald, Daniel Horace. Spirit's Philosophical Bildung: Image and Rhetoric in Hegel's Phenomenology of the Spirit and Science Logic. Maryland: University Press of America, 2004. Impreso.

Fernández Juncos, Manuel. Semblanzas puertorriqueñas. Tip. de J. González Font, 1888. 202. eBook. books.google.com.

Franz, Thomas R. Remaking Reality in Galdós: A Writer's Interactions with his Context. Ohio: Strathmore Press, 1982.

Gadamer, Hans-Georg, y P C. Smith. Hegel's Dialectic: Five Hermeneutical Studies. New Haven: Yale University Press, 1976. Impreso.

García Díaz, Manual. Alejandro Tapia y Rivera: Su vida y su obra. San Juan: Editorial Coquí, 1964. Impreso.

García López, José. Historia de la literatura española. Barcelona: Editorial Vicéns-Vives, 1987. Impreso.

Gillespie, Gerald. "Reality and Fiction in the Novels of Galdós." Galdós. Ed. Jo Labanyi. London: Longman, 1993. 77-102. Impreso.

Giner de los Ríos, Francisco. Ensayos. Madrid: Alianza Editorial, S.A., 1969. Impreso.

Gold, Hazel. The reframing of realism: Galdós and the Discourses of the Nineteenth-Century Spanish Novel. Duke University Press Books, 1993. Impreso.

Goldman, Peter B. Conflicting Realities: Four Readings of a Chapter by Galdós. Londres: Thamesis, 1984. Impreso.

---. "Galdós and the Nineteenth-century Novel: The Need for an Interdisciplinary Approach." Galdós. Ed. Jo Labanyi. London: Longman, 1993. 140-56. Impreso.

Gómez-Martínez, José Luis. "Galdós y el krausismo español". Nueva Revista de Filología Hispánica . 22.1 (1983): 234-45. Impreso.

González Pérez, Aníbal. "La Cuarterona and Slave Society in Cuba and Puerto Rico." Latin American Literary Review 8.16 (1980): 47-54.

Goodrick-Clarke, Nicholas. The Western Esoteric Traditions: A Historical Introduction. New York: Oxford University Press, 2008. Impreso.

Greene, Brian. The Fabric of the Cosmos: Space, Time, and the Texture of Reality. New York: Alfred A. Knopf, 2004. Impreso. 
Greer, John Michael. "An Introduction to the Corpus Hermeticum." sacred-texts.com Web. 30 jul. 2010.

Greene, Murray. Hegel on the Soul: A Speculative Anthropology. The Hague: 1972. Impreso.

Gullón, German. "La sombra, novela de suspense y novela fantástica". Actas del Primer Congreso Internacionald de Estudios Galdosianos. (1977): 351-56.

Gullón, Ricardo. Galdós, novelista moderno. Madrid: Gredos, 1966. Impreso.

Gutiérrez Diáz-Bernardo, Esteban. Benito Pérez Galdós: 13 cuentos. Madrid: Edaf, 2001. Impreso.

Harris, H.S. Hegel's Development: Night Thoughts (Jena 1801-1806). Oxford: Clarendon Press, 1983. Impreso.

Hegel, Georg Wilhelm Friedrich. Lectures on the Philosophy of Spirit 1827-8. Oxford: University Press, 2007. Impreso.

---. Filosofía del espíritu. Buenos Aires: Claridad, S.A., 1969. Impreso.

---. Fenomenología del espíritu. México: Fondo de Cultura Económica, 1966. Impreso.

---. Lectures on the Philosophy of the Spirit. Ed. Robert R. Williams New York: Oxford University Press, 2007. Impreso.

Hermes. Los libros de Hermes Trismegisto. Barcelona: Edicomunicacioón, 1998. Impreso.

Hoddie, James H. Echegaray and Galdós; Ties between El gran Galeoto and Tormento. Romanistisches Jahrbuch, Berlin, New York, 2009. Impreso.

Hornung, Erik. The Secret Lore of Egypt: Its Impact on the West. Ithaca: Cornell University Press, 2001. Impreso.

Hutchins, Kimberly and Pulkkinen Tuija. Hegel's Philosophy and Feminist Thought: Beyond Antigone? New York: Palgrave Macmillan, 2010. Impreso.

Kant, Immanuel. Critique of Pure Reason. New Cork: The Colonial Press, 1899. Impreso. 
Kelly, Eugene. The Basics of Western Philosophy. Connecticut: Greenwood Press, 2004. Impreso.

Kerkhoff, Manfred. Kairos: Exploraciones ocasionales en torno a tiempo y destiempo. San Juan: Editorial de la Universidad de Puerto Rico, 1997. Impreso.

Labanyi, Jo. Galdós. London: Longman Group UK Limited, 1993. Impreso.

Lázaro, Helena. "Introducción”. Tapia ayer y hoy: Edición conmemorativa 1882- 1982. Santurce, Puerto Rico: Universidad del Sagrado Corazón, 1-7. 1982. Impreso.

Lipp Solomon. Francisco Giner de los Ríos: A Spanish Socrates. Ontario: Wilfred Laurier University Press, 1985. Impreso.

López-Morillas, Juan. El krausismo español. México: Fondo de Cultura Económica, 1956. Impreso.

Magee, Glenn Alexander. Hegel and the Hermetic Tradition. Ithaca: Cornell University Press, 2001. Impreso.

Mahé, Jean-Pierre, "Hermes Trismegistus" in The Encyclopedia of Religion, Vol. 6. New York: Macmillan, 1987. Impreso.

Manrique Cabrera, Francisco. Historia de la literatura puertorriqueña. Río Piedras, Puerto Rico: Editorial Cultural, 1986. Impreso.

Martell-Morales, Héctor J. "Literatura fantástica de Puerto Rico del siglo XIX.". Diss. Universidad de Puerto Rico, 2008. ProQuest. 17 dic 2008.

Mayer, Frederick. A History of Modern Philosophy. New York: American Book Company, 1951. Impreso.

McGovern, Timothy. Galdós Beyond Realism: Reading and the Creation of Magical Worlds. Delaware: Juan de la Cuesta, 2004. Impreso.

Menéndez y Pelayo, Marcelino. Historia de los heterodoxos españoles. VIII. Madrid: Consejo Superior de Investigaciones Científicas, 1965. Impreso.

---. Historia de la Poesía Hispano-Americana. Madrid: General de Victoriano Suárez, 1911 y 1913. Edición digital: Alicante : Biblioteca Virtual Miguel de Cervantes, 2008 
Miralles, Enrique. "La importante levedad de los cuentos de Galdós". bibliotecamiralles.org N.p.. Web. 11 Nov 2011.

Montesinos, José. Galdós: Estudios sobre la novela española del siglo XIX. vol. 1. Editorial Castalia: Madrid,1968. Impreso.

Moreira, Rubén Alejandro. "Introducción". Actas de Tapia: actas del Congreso Alejandro Tapia y Rivera. Ed. Rubén Alejandro Moreira. Humacao: U.P.R., Editorial LEA, Ateneo Puertorriqueño, 2005. Impreso. 012210

Oleza, Joan. "Galdós y la ideología burguesa en España: de la identificación a la crisis." Biblioteca Virtual Miguel de Cervantes. U de Alicante. 31 Oct. 2002.

Olivera, Otto. La literatura en periódicos y revistas de Puerto Rico, Siglo XIX. Río Piedras: Editorial de la Universidad de Puerto Rico, 1987. Impreso.

Ortiz-Armengol, Pedro. Vida de Galdós. Barcelona: Ed. Crítica, 2000. Impreso.

Neumann, Erich. The Great Mother: An Analysis of the Archetype. Trans. R. Manheim. Bollingen Series 47. Princeton, NJ: Princeton UP, 1963. Impreso.

Pallardo, Garrido F. Los orígenes del romanticismo. Barcelona: Labor S.A., 1968. Impreso.

Paravisini-Gebert, Lizabeth. "Caribbean Literature in Spanish." faculty.vassar.edu N.p.. Web. 27 Mar 2010.

Percival, Anthony. Galdós and his Critics. Toronto: University of Toronto Press, 1985. Impreso.

Pérez Galdós, Benito. "Celín”. 13 cuentos. Ed. Gutiérrez Diáz-Bernardo, Esteban. Madrid: Edaf, 2001.

Pérez, Galdós B, and Rodolfo Cardona. La Sombra de Galdós: Libro de Lectura, Repaso y Conversación. New York: Norton, 1966. 293-344. Impreso.

Picknett, Lynn, and Clive Prince. The Forbidden Universe: The Occult Origins of Science and the Search for the Mind of God. Londres: Skyhorse Pub Co. Inc, 2011. Impreso. 
Picó, Fernando. Historia general de Puerto Rico. 3rd ed., Río Piedras: Ediciones Huracán, 1986. Impreso.

Platón. Diálogos. Buenos Aires: Espasa-Calpe: Argentina, 1943. Impreso.

Rivera, Ángel A. Eugenio María de Hostos y Alejandro Tapia y Rivera: Avatares de una modernidad Caribeña. New York: Peter Lang, 2001. Impreso.

Rivera de Álvarez, Josefina. Visión histórico-crítica de la literatura puertorriqueña. Instituto de Cultura Puertorriqueña, San Juan, 1960. Impreso.

Rodgers, Eamonn. "Liberalismo y religión en Galdós." Analecta Malacitana (AnMal electrónica) 2 121-130. 1999

Román-Eyxarch, Jazmine. "La estética de las novelas de Alejandro Tapia y Rivera en la formación de una etnia puertorriqueña." Diss. Temple University, 1991.

Rosa-Nieves, Cesáreo. Historia panorámica de la literatura puertorriqueña. San Juan: Editorial Campos, 1963. Impreso.

---. Plumas estelares en las letras de Puerto Rico, Tomo I - Siglo XIX. San Juan: Ediciones de la Torre, 1967. Impreso.

Rosa-Nieves, Cesáreo y Franco-Oppenheimer, Félix. Antología general del cuento puertorriqueño. tomo 1. San Juan. Barcelona: Ediciones Rumbo, 1959. Impreso.

Russell Bertrand. History of Western Philosophy. Londres: Routledge Classics, 1996. Impreso.

Salaman, Clement. Asclepius: The Perfect Discourse of Hermes Trismegistus. Londres: Duckworth, 2007. Impreso.

Saldivia-Berlung. Saldivia-Berlung , Marcela. "Espiritismo as a Literary Strategy of Gender Representation and Cultural Resistance in Nineteenth-Century Puerto Rican Fiction." Identidades. 4. enero (2007)

Sanz del Río, Julián. "Discurso pronunciado en la Universidad Central. Inauguración del año académico de 1857 a 1858". ensayistas.org Web. 12 mar 2012.

---. "Ideal de la humanidad para la vida" biblioteca.org.ar .pdf 
Schraibman, José. "Galdós, o el canon enterrado". Alicante: Biblioteca Virtual Miguel de Cervantes, 2002. 34-45. Web.

Schulman, Marcy G. "Ironic Illusion in La Sombra." Anales galdosianos. 55-67

Serreau, Rene. Hegel y el Hegelianismo. Buenos Aires: Editorial Universitaria de Buenos Aires, 1964. Impreso.

Smith, Alan E. Los cuentos inverosímiles de Galdós en el contexto de su obra. Barcelona: Anthropos, 1992. Impreso.

Suko, Aaron M. M. On Becoming Virginia: The Story Of A Man Who Crashed A Woman's Body: "A Translation of Alejandro Tapia y Rivera's Póstumo El Envirginiado" [1882.] Diss. University Of Massachusetts Amherst, 2009.

Seligman, Kurt. Magic, Supernaturalism and Religion. New York: Panteón Books, 1948. Impreso.

Stuckrad, Kocku. Western Esotericism: A Brief History of Secret Knowledge. London: Equinox Pub, 2005. Impreso.

Tapia y Rivera, Alejandro. "Conferencias sobre estética y literatura". Biblioteca digital puertorriqueña de la Universidad de Puerto Rico. Web 29 de noviembre de 2007.

--- . Póstumo el transmigrado. Obras completas. San Juan: Instituto de Cultura Puertorriqueña, 1968. Impreso.

---. "Un alma en pena". Biblioteca Virtual Cervantes. Web 23 de septiembre de 2007.

---. Noticia histórica de Don Ramon Power, primer diputado de Puerto-Rico. Ediciones Rumbos: Barcelona, 1967.

Todorov, Tzvetan. The Fantastic: A Structural Approach to a Literary Genre. Ithaca, N.Y: Cornell University Press, 1975. Impreso.

Tres iniciados. El kybalión. Buenos Aires: Kier, 2007. Impreso.

Trismegisto, Hermes. Los libros de Hermes Trismegisto. Barcelona: Edicomunicación, 1998. Impreso.

Vicéns-Vives, Jaime. Historia de España y América. Barcelona: Editorial Vicéns-Vives,1965. Impreso. 
Vondung, Klaus. "Millenarism, Hermeticism, and the Search for Universal Science," en Stephan McKnight ed., Science, Pseudo-Science, and Utopianism in Early Modern Thought. Columbia, Missouri: University of Minnesota Press, 1992. Impreso.

Voss Karen-Claire. "Imagination In Mysticism And Esotericism: Marsilio Ficino, Ignatius de Loyola, and Alchemy". Studies in Spirituality No. 6, 1996,106-130.

Wamester Bares, Sarah. "The Puerto Rican Novel 1849-1910 Somatic Fictions of Identity: Writing Nationality on the Limits" Diss. New York University May, 2008.

Webber, Andrew. The Doppelganger: Double Visions in German Literature. New York: Oxford University Press, 2003. Impreso.

Wilson, Colin. The Occult; a History. New York: Vintage, 1973. Impreso.

Winfield, Richard D. Hegel and Mind: Rethinking Philosophical Psychology. Basingstoke, England: Palgrave Macmillan, 2010. Impreso.

Yates, Frances. Giordano Bruno and the Hermetic Tradition. New York: Random House, 1966. Impreso.

Ynduráin, Francisco. "La sombra: Una interpretación". Actas del Primer Congreso Internacionald de Estudios Galdosianos. Madrid: Editora Nacional, Ediciones del Excmo. Cabildo Insular, 1977. 351-56. Actas III, Tomo II

Zavala, Iris M. "Románticos y rebeldes". Sin Nombre, 8 abr-jun 1977 7-19 
VITA

AGNES RUIZ-LÓPEZ

\section{EDUCATION}

2013

1997

1986

1989
FLORIDA INTERNATIONAL UNIVERSITY

Ph.D. Candidate in Spanish

UNIVERSITY OF PUERTO RICO

Master of Arts in Translation

Bachelor of Arts in Modern Languages

UNIVERSITY OF REGENSBURG, GERMANY

German Studies

PROFESSIONAL HISTORY

2013

2007-2013

2000-2007

1995-1999

1995-1996

MEMBERSHIPS

Phi Kappa Phi - National Honor Society

Modern Language Association (MLA)

LANGUAGES

Adjunct Professor - Spanish

Teaching Assistant - Spanish

Translator/Proofreader

Miami, Florida

UNIVERSITY OF PUERTO RICO

Instructor - Spanish Instructor - Italian and German
FLORIDA INTERNATIONAL UNIVERSITY

ACCENTMARKETING COMMUNICATIONS

INTERAMERICAN UNIVERSITY OF PUERTO RICO

Fluent in Spanish and English

Working knowledge of Italian, German, French, and Portuguese 